\title{
Storage and Turnover of Organic Matter in Soil
}

TORN, M.S., Lawrence Berkeley National Laboratory and University of California, Berkeley, USA.

C.W. SWANSTON, USDA Forest Service, Northern Research Station, Houghton, USA

C. CASTANHA, Lawrence Berkeley National Laboratory, Berkeley, USA

S.E. TRUMBORE, University of California, Irvine, USA 


\section{TABLE OF CONTENTS}

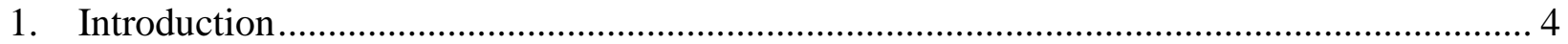

2. The Amount of Organic Carbon Stored in Soils.............................................................. 5

2.1. Empirical Estimates of Global Carbon Stocks in Soils ............................................... 5

2.2. Understanding variation in Carbon storage across the landscape .................................. 7

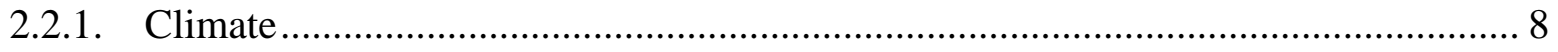

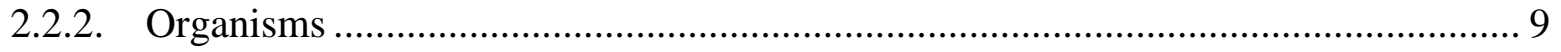

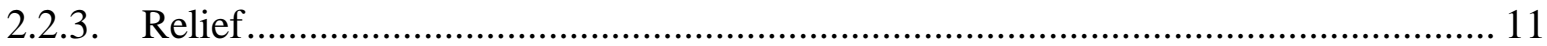

2.2.4. Parent Material .......................................................................................... 12

2.2.5. Time ...................................................................................................... 13

2.2.6. Opportunities and Drawbacks to Gradient Studies and Other Approaches ............. 14

3. Turnover Time and Dynamics of Soil Organic Matter................................................. 16

3.1. Metrics of Carbon Dynamics .................................................................................. 17

3.2. Observational Constraints for Determining soil Carbon Dynamics ................................ 20

3.2.1. Litter Decomposition Experiments ................................................................ 20

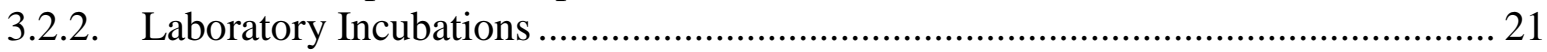

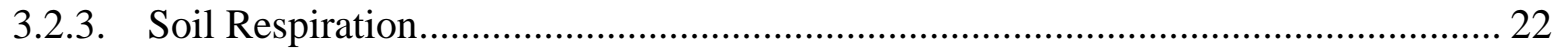

3.2.4. Isotopic Tools: Tracers .............................................................................. 24

3.2.5. Natural Abundance Stable Carbon Isotopes $\left({ }^{13} \mathrm{C}\right)$......................................... 25

3.2.6. Radiocarbon ...................................................................................... 26

3.2.7. Fractionation of Soil Organic Matter ............................................................. 28

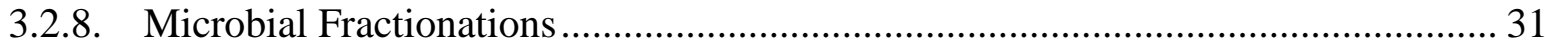

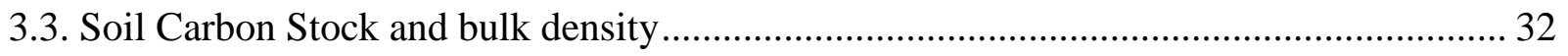

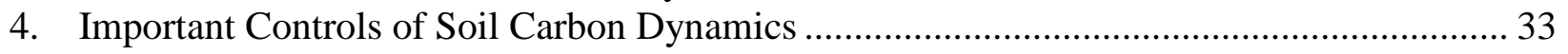

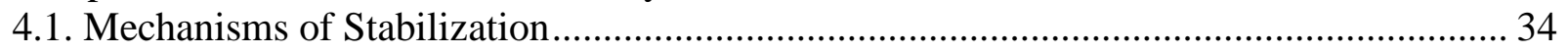

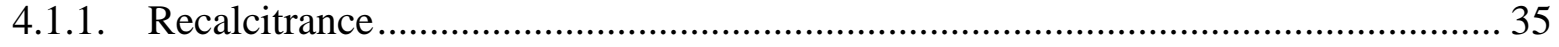

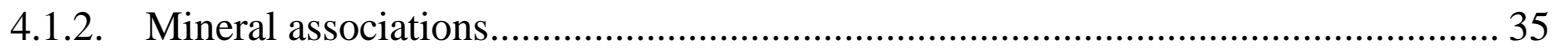

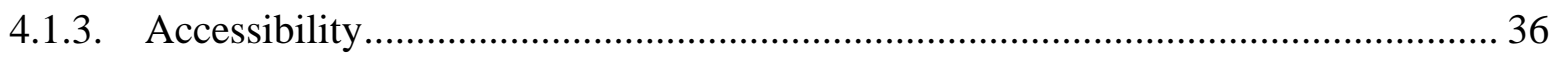

4.1.4. Biotic suppression and climatic stabilization............................................. 37

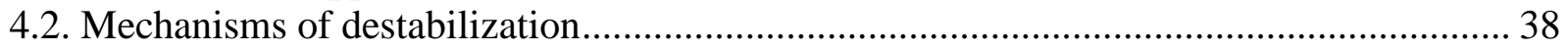

4.3. Temporal and Spatial Scales of Carbon Cycling .................................................. 38

5. Responses of Soil Organic Matter to Global Environmental Change ............................... 40

5.1. Productivity and Soil Carbon Storage ...................................................................... 40

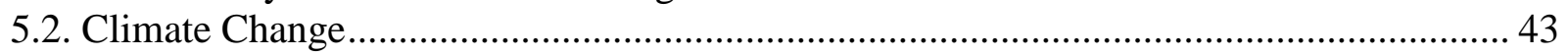

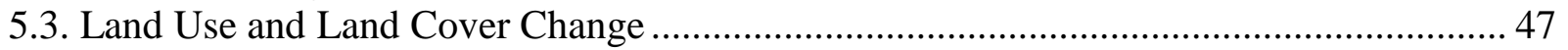

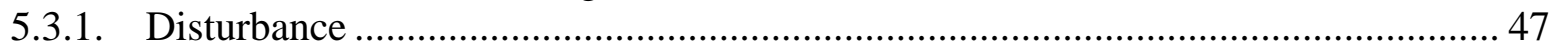

5.3.2. Land Management ................................................................................. 48

5.4. Temporal Dimensions of Soils as Sources or Sinks of Carbon .................................. 49

6. Conclusions and Future Prospects ......................................................................... 50

7. Appendix 1. Methods of Radiocarbon $\left({ }^{14} \mathrm{C}\right)$ Analysis and Reporting of ${ }^{14} \mathrm{C}$ Data .............. 53

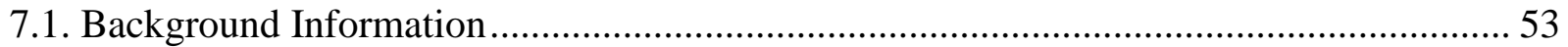

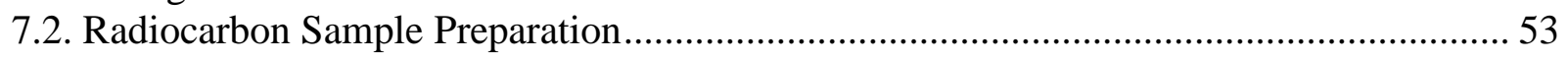

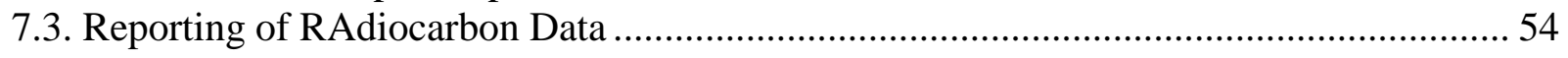

8. Appendix 2. Modeling Carbon Dynamics Using Radiocarbon Measurements .................... 58

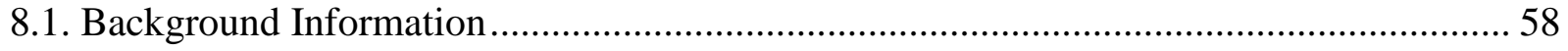

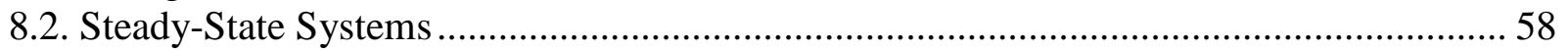


8.2.1. Natural Radiocarbon - for samples collected prior to 1950, or assumed to contain

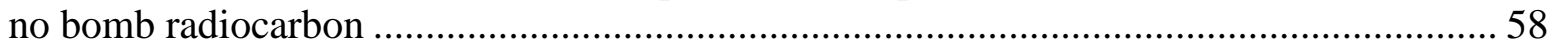

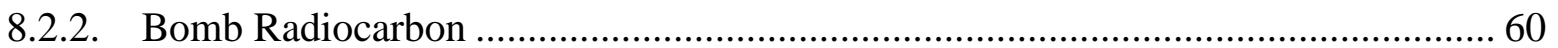

8.2.3. Systems That Are Accumulating Soil Carbon ................................................. 62

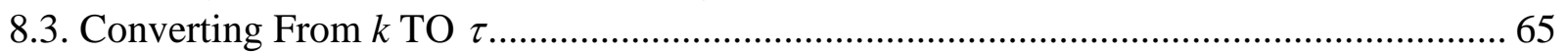

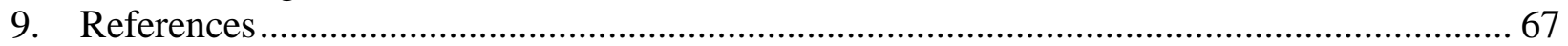

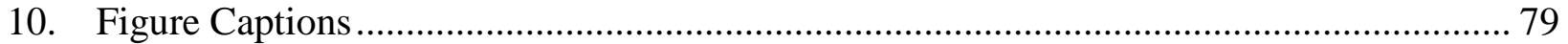




\section{INTRODUCTION}

Historically, attention on soil organic matter (SOM) has focused on the central role that it plays in ecosystem fertility and soil properties, but in the past two decades the role of soil organic carbon in moderating atmospheric $\mathrm{CO}_{2}$ concentrations has emerged as a critical research area. This chapter will focus on the storage and turnover of natural organic matter in soil (SOM), in the context of the global carbon cycle.

Organic matter in soils is the largest carbon reservoir in rapid exchange with atmospheric $\mathrm{CO}_{2}$, and is thus important as a potential source and sink of greenhouse gases over time scales of human concern (Fischlin and Gyalistras 1997). SOM is also an important human resource under active management in agricultural and range lands worldwide. Questions driving present research on the soil $\mathrm{C}$ cycle include: Are soils now acting as a net source or sink of carbon to the atmosphere? What role will soils play as a natural modulator or amplifier of climatic warming? How is $\mathrm{C}$ stabilized and sequestered, and what are effective management techniques to foster these processes? Answering these questions will require a mechanistic understanding of how and where $\mathrm{C}$ is stored in soils.

The quantity and composition of organic matter in soil reflect the long-term balance between plant carbon inputs and microbial decomposition, as well as other loss processes such as fire, erosion, and leaching. The processes driving soil carbon storage and turnover are complex and involve influences at molecular to global scales. Moreover, the relative importance of these processes varies according to the temporal and spatial scales being considered; a process that is important at the regional scale may not be critical at the pedon scale. At the regional scale, SOM cycling is influenced by factors such as climate and parent material, which affect plant 
productivity and soil development. More locally, factors such as plant tissue quality and soil mineralogy affect decomposition pathways and stabilization. These factors influence the stability of SOM in part by shaping its molecular characteristics, which play a fundamental role in nearly all processes governing SOM stability but are not the focus of this chapter.

We review here the most important controls on the distribution and dynamics of SOM at plot to global scales, and methods used to study them. We also explore the concepts of controls, processes, and mechanisms, and how they operate across scales. The concept of SOM turnover, or mean residence time, is central to this chapter and so it is described in some detail. The Appendix details the use of radiocarbon $\left({ }^{14} \mathrm{C}\right)$, a powerful isotopic tool for studying SOM dynamics. Much of the material here was originally presented at a NATO Advanced Study Institute on "Soils and Global Change: Carbon Cycle, Trace Gas Exchange and Hydrology, held June 16-27, 1997, at the Chateau de Bonas, France.

\section{THE AMOUNT OF ORGANIC CARBON STORED IN SOILS}

In this section we summarize current estimates of $\mathrm{C}$ stocks in soils and explore the factors predicting broad-scale patterns in soil $\mathrm{C}$ storage.

\subsection{EMPIRICAL ESTIMATES OF GLOBAL CARBON STOCKS IN SOILS}

Most assessments of global soil C stocks have included only the top meter of soil, but recent estimates have encompassed lower depths. Historical global estimates for the top meter of soil ranged from 800 to $2,400 \mathrm{Pg} \mathrm{C}$, converging on the range of 1,300-1,600 Pg C to $1 \mathrm{~m}$. Batjes (1996) estimated that an additional $900 \mathrm{Pg} \mathrm{C}$ is stored between 1 and $2 \mathrm{~m}$ depth, and Jobbágy and Jackson (2000) revised that estimate to $500 \mathrm{Pg}$ between 1 and $2 \mathrm{~m}$ and another $350 \mathrm{Pg}$ between 2 and $3 \mathrm{~m}$ depth. Global organic $\mathrm{C}$ stocks to $3 \mathrm{~m}$ are currently estimated at 2,300 $\mathrm{Pg}$, 
with an additional 1,000 Pg contained in permafrost and peatlands (Jobbagy and Jackson 2000;

Zimov et al. 2006). Soil C distribution with ecosystem type is shown in Figure 1.

Two general approaches have been taken to estimate the global soil $\mathrm{C}$ inventory from soil profile data. The first, used by Schlesinger (1977) and Post et al. (1982), relates C storage to climate and vegetation (for example, expressed as Holdridge life zone classifications). For example, Post et al. (1982) generated relationships of climate and vegetation with soil C using 2,700 soil profiles, and used these to calculate a global soil $\mathrm{C}$ inventory of $1,400 \mathrm{Pg} \mathrm{C}$ in the top $1 \mathrm{~m}$. A second approach uses soil mapping units for extrapolation (Eswaran et al. 1993; Batjes 1996). Eswaran (1993) determined the average $C$ inventory for each soil order, based on data from roughly 1,000 pedons from FAO/UNESCO and 15,000 profiles from U.S. Dept. of Agriculture databases. This soil map-based estimate of soil $\mathrm{C}$ inventory globally is $1,600 \mathrm{Pg} \mathrm{C}$ in the top $1 \mathrm{~m}$. Batjes (1996), using a database of 4,353 soil profiles considered to be representative of soil units on the FAO map, estimated $1,500 \mathrm{Pg}$ soil organic $\mathrm{C}$ to $1 \mathrm{~m}$ depth.

Regardless of approach, these global inventories are acknowledged to underestimate the total amount of dead organic matter in ecosystems because they do not include important reservoirs. All omit $\mathrm{C}$ stored in surface detritus (including the $\mathrm{O}$ horizon), which contains an additional 50-200 Pg C (Matthews 1997). Moreover, some soils contain significant soil C even below 3 meters. For example, some tropical soils and many Histosols contain as much C below 1 $\mathrm{m}$ as they do above $1 \mathrm{~m}$ (Eswaran et al. 1993; Nepstad et al. 1994). In general, highly weathered soils are often very deep (tens of meters) so that even very low C concentrations may add up to a large amount of stored C in the total (Sombroek et al. 1993). Finally, most soil C estimates do not include organic $\mathrm{C}$ in permafrost or paleosols, a reservoir containing roughly $900 \mathrm{Pg} \mathrm{C}$ in the boreal and arctic regions alone (Figure 1). 
Not surprisingly, given that they are extrapolations of point observations, global C inventories have large uncertainties. Post et al. (1982) estimate an error of $\pm 200 \mathrm{Pg} \mathrm{C}(14 \%)$, reflecting the variability in soil C inventory within each life zone category. Eswaran et al. (1993) show large coefficients of variation, of $28-70 \%$, for soils within given soil classification categories. Much of the profile data employed in these estimates includes only carbon density and not bulk density, so that the bulk density must be estimated from empirical relationships between $\mathrm{C}$ density and bulk density developed from profiles where both were measured (Zinke et al. 1984).

\subsection{UNDERSTANDING VARIATION IN CARBON STORAGE ACROSS THE LANDSCAPE}

Constructing estimates of the amount of $\mathrm{C}$ stored in soils requires extrapolating from individual soil profiles to larger regions. Likewise, model simulations of soil C stocks require quantitative relationships with the factors controlling stocks, and distributed data for model testing. For all these reasons, we need to link soil $\mathrm{C}$ to factors that are mapped or modeled, globally. Moreover, linking soil C storage to environmental factors at broad spatial and temporal scales will help us gain insight into the large-scale controls on $\mathrm{C}$ cycling.

Are there predictable ways in which $\mathrm{C}$ storage varies across the landscape? Jenny (Jenny 1941), expanding on an approach by Dokuchaev (Glinka 1927; Jenny 1941) and Rizpolozhenski (Lapenis et al. 2000), suggested that soil properties—including C inventory—-may be predicted from soil forming, or "state", factors. This concept is expressed by the "clorpt" equation:

Soil property (in this case, SOM inventory) $=f(\mathrm{cl}, \mathrm{o}, \mathrm{r}, \mathrm{p}, \mathrm{t})$, 
where $\mathrm{cl}=$ climate, $\mathrm{o}=$ potential organisms $($ vegetation and fauna), $\mathrm{r}=$ relief $($ aspect and topography) $\mathrm{p}=$ parent material, and $\mathrm{t}=$ time. One of Jenny's important contributions was to develop the experimental approach—carefully selected sets of sites that isolate the state variables of interest-that derives from the clorpt relation (Amundson and Jenny 1997). In this approach, sites are selected such that the variable (state factor) of interest varies while all other important factors are held relatively constant. For example, to understand the influence of temperature regimes, Jenny located a series of sites with the same soil age (time), biota, parent material, and precipitation but with different temperature regimes. In contrast, interpreting the influence of, for example, temperature, from gradients in which other state factors vary (such as elevation gradients in which parent material also varies) is difficult.

Note that each state factor can influence soil carbon storage in two ways: by influencing the quantity and quality of plant inputs and by influencing the residence time of organic matter in the soil. Figures 2, 3, and 4 show the influence of three state factors on soil C storage. Many of the descriptions of state factors below touch upon the importance of controls on SOM stabilization, and these controls are discussed further in a following section.

\subsubsection{Climate}

Climate has an overriding influence on large scale patterns in ecosystem properties, including soil $\mathrm{C}$ cycling, through its control of plant community composition and productivity (Holdridge 1947), which affect the quantity and quality of inputs to the SOM pool, as well as of microbial community composition and decomposition activity. Climate acts over a range of timescales as well, influencing which minerals are the stable weathering products, whether physical or chemical erosion processes dominate the landscape, and rates of microbial decay compared to other removal processes. 
Jenny's research is exemplary for both our understanding of climate and soil, and applying the state factor approach. Jenny (1930) measured nitrogen (N, and carbon) storage in soil sampled across the U.S. Great Plains (Figure 2), where the parent material consists largely of loess deposited during the last glacial period. In this region, precipitation increases from west-toeast, while mean annual temperature varies from north (coldest) to south (warmest). By comparing soils at the same latitude but different longitude, the gradient in temperature is isolated from variation in mean precipitation, vegetation, and parent material. By comparing soils across latitude, one can isolate the effect of precipitation. Jenny used the variation in climate across the Great Plains to explore the controls of both temperature and moisture on SOM. Carbon stocks were largest toward the cooler and wetter northeast, and smallest in the hotter and drier southwest (Jenny 1930 as cited by Jenny, 1941). More generally, decomposition is more sensitive to climate than is productivity, so that, all else equal, higher latitudes and elevations tend to have larger $\mathrm{C}$ stock that tropical or low elevation ecosystems.

\subsubsection{Organisms}

Organisms - including plants, animals, and soil microbes - control the chemical form and location of organic matter input to soils. In an analysis of more than 2,700 soil profiles from three global databases, Jobbágy and Jackson (2000) found that vegetation type was closely correlated with the amount of soil carbon and its distribution with depth. Vegetation controls $\mathrm{C}$ cycling in several ways, some of which covary with climate. First, net primary productivity, which depends on plant species and communities, determines $\mathrm{C}$ input rates to soil. For soils with similar decomposition rates, those with more productive vegetation will have higher organic $\mathrm{C}$ inventories. For example, soil carbon losses after forest conversion to pasture or agriculture are partly attributed to decreases in primary productivity (Trumbore et al. 1995). Second, vegetation 
type affects tissue chemistry and seasonality of inputs. Finally, plant species differ in the proportion of photosynthate partitioned to roots, shoots, or woody structures. Since roots comprise a large fraction of plant inputs to soil, and soil C decomposition decreases with depth, the depth-distribution of root inputs affects soil C storage. All of these attributes have large effects on the transformation and stabilization of organic matter (Steinmann et al. 2004; Bird and Torn 2006; Zanelli et al. 2006).

While litter chemistry clearly influences initial decomposition rates, the influence of plant tissue chemistry on the structure and decomposability of soil organic matter is a current and unresolved research question. For example, rates of litter and root decomposition have been correlated with lignin, nitrogen, and non-structural carbohydrate content (Melillo et al. 1982; Berg et al. 2001; Zhang et al. 2008), but many initially recalcitrant compounds like lignin do not persist in soils (Luttzow et al. 2007). Quideau et al. (1998) found that only 50 years after being planted with different vegetation types, adjacent sites with the same parent material, soil age, and climate had several-fold differences in soil C stock and differences in SOM chemistry, documented by ${ }^{13} \mathrm{C}$ nuclear magnetic resonance, corresponding to the different vegetation inputs.

Fauna also influence soil carbon cycling. Bioturbation mixes and aerates soil, physically breaks down litter, creates flow paths for water in soil, and can reduce surface litter stocks and enhance erosion (Bohlen et al. 2004). For example, along a gradient of European earthworm (Lumbricus terrestris) colonization in a deciduous forest of northern Michigan, earthworms are associated with a decrease in litter-layer thickness, apparently mixing some forest floor organic matter into the mineral soil. Thus fauna can create spatial patterns in SOM stocks.

In addition to being the enzymatic agents of biotic decomposition of SOM, microbial cell by-products are increasingly recognized as major building blocks of soil organic matter. As a 
result, the microbial community, controlled by climate, vegetation, and soil environment, is a key mediator of organic matter composition and decomposition. The spatial scales of influence, however, have not been well characterized.

\subsubsection{Relief}

Factors like soil slope, drainage, and erosion create significant variations in $\mathrm{C}$ stock within and among watersheds. For instance, poorly drained soils tend to have high $\mathrm{C}$ stocks due to low availability of $\mathrm{O}_{2}$ for decomposition. Erosion is a key process underlying landscape patterns. Erosion redistributes nutrient-rich topsoil downhill, increasing fertility in depositional environments and potentially reducing it in eroding environments ones. The effects of erosion on decomposition are more complicated. Transport of particles breaks down aggregates and increases SOM accessibility for decomposition. On the other hand, burial of eroded C in depositional settings can reduce its decomposition rate (Berhe et al. 2007).

These patterns and processes are particularly important when considering how representative specific soil profiles are of regional soil C storage (Davidson and Lefebvre 1993), and in evaluating the effects of land cover and use change, if it alters erosion rates, on terrestrial C stocks. In terms of spatial patterns within watersheds, $\mathrm{C}$ inventories are typically higher at the bottom of slopes for two reasons. Lower slope positions have slower decomposition as a result of fine texture, low $\mathrm{O}_{2}$, and burial. They also tend to have higher inputs relative to upper slope positions from higher productivity and deposition of eroded material.

In terms of total watershed $\mathrm{C}$ stock, recent empirical and modeling studies conclude that erosion - and the balance between its effects on productivity and decomposition in eroding and depositional sites_-tends to lead to an increase in stock, even if there are local decreases in the eroding sites themselves (Stallard 1998; Smith et al. 2005; Berhe et al. 2007; Harden et al. 1999). 
The rate at which $\mathrm{C}$ accumulates in a watershed due to erosion and deposition depends on the strength of erosion and management of productivity, as well as the types of depositional settings involved (Berhe et al., 2007; van Oost et al. 2007).

Because so much land area is subject to erosion, this watershed-increase in soil C scales to a large global C sink. Erosion by wind and water affects roughly $10 \times 10^{12} \mathrm{~m}^{2}$ of land worldwide (Jacinthe and Lal 2001) and moves 1-5 $\mathrm{Pg} \mathrm{C} \mathrm{y}^{-1}$, with more than 70\% deposited terrestrially (Stallard, 1998). As a result of the erosion effects on decomposition and NPP described above, recent studies have suggested that erosion results in a global terrestrial $\mathrm{C}$ sink of $0.25-1 \mathrm{Pg} \mathrm{C}^{-1}$ (Stallard 1998; Smith et al. 2005; Berhe et al. 2007; van Oost et al. 2007).

\subsubsection{Parent Material}

An analysis of worldwide data shows differences in carbon storage among parent materials, in spite of the fact that it does not control for confounding factors such as soil age (Zinke et al. 1984) (Figure 4). Parent material — the mineral substrate at the inception of soil developmenthas a variety of influences over SOM stocks. It affects the chemistry and fertility of soil and thus plant productivity ( $\mathrm{C}$ inputs to soil); texture, which affects soil moisture retention and thus both productivity and decomposition; and clay content and mineralogy which affect SOM stabilization. For example, soils developed on volcanic ash or rocks of basic $\mathrm{pH}$ often contain more organic carbon than those formed on granitic or acidic parent material (e.g., (Harradine and Jenny 1958; Marti and Badia 1995). Jenny (1980) found increasing C density with increasing loess in soils developed on postglacial till, a pattern he ascribed to finer texture (Figure 5). Indeed, soil texture, particularly clay content, is positively correlated with $\mathrm{C}$ storage in many sites and is used as the proxy for mineral control of stabilization in most ecosystem $\mathrm{C}$ models. The reliance on texture as a proxy for mineral stabilization is changing very rapidly, however. 
Recent studies suggest that storage and turnover are much more closely related to mineral properties, in particular the poorly crystalline phases, than to texture per se (Torn et al. 1997; Masiello et al. 2004; Basile-Doelsch et al. 2005; Kleber et al. 2005). For example, in paired forest soils derived from granitic vs. andesitic parent materials, the latter stored almost 50\% more C than did the granitic soils despite similar levels of clay and aggregate stability, climate, and vegetation (Rasmussen et al. 2005). Based on these and other recent studies, the amount of mineral-associated $\mathrm{C}$ appears correlated with reactive iron and aluminum in short-range-order minerals and humic complexes, and their interaction with aggregates.

\subsubsection{Time}

Soils develop over time. Soil profiles thicken and carbon stocks increase with time and soil age, during early-to-mid stages of development, but may decrease as soils become highly weathered. A chronosequence is a series of sites that vary in the period of time over which the soil has developed, or since significant disturbance. In a state factor experiment, all the sites in the chronosequence would have similar climate history, parent material, and, unless included in the study design, vegetation species. Such sequences have been constructed from terraces formed by coastal uplift or rivers, glacier retreat, and volcanic deposits. A chronosequence in Hawai'i, developed on ash deposits of different ages (Chadwick et al. 1999) illustrates a trend seen in other, similar studies (Jahn et al. 1992; Percival et al. 2000). Soil organic carbon accumulates for the first several-hundred-thousand years of soil development, then declines in very old soils (older than a million years). The slow build up and subsequent decline of carbon has been correlated with changes in the amount and type of soil minerals that can stabilize SOM (e.g., Oades 1989), for example in the amount of reactive iron and aluminum and non-crystalline, 
secondary minerals like allophane and imogolite, which have large reactive surface areas and stabilize organic compounds (Jahn et al. 1992; Torn et al. 1997; Masiello et al. 2004) ( Figure 5).

In many cases, the differences in $\mathrm{C}$ storage among soils developed on different parent materials decrease as soils reach great age (millions of years). We speculate that over millions of years, the mineral content and the mineral-associated organic $\mathrm{C}$ content of different soils tends to converge to a state predicted or constrained by climate.

\subsubsection{Opportunities and Drawbacks to Gradient Studies and Other Approaches}

These state factors provide general rules for predicting how $\mathrm{C}$ inventory in soils will vary across large regions and over long time scales. The largest organic $\mathrm{C}$ inventory should be in cool, wet climates with high ecosystem productivity, on young volcanic surfaces (as in the Pacific Northwest of the United States). The smallest C stocks should be found in hot, arid regions of low productivity (as in deserts). Another observation, put forth by Jenny, is that the major reservoirs of soil carbon change with latitude: at low latitudes, very little of the total soil $\mathrm{C}$ is stored in surface detritus and most of the $\mathrm{C}$ is in the mineral soil. At high latitudes, slow litter decay leads to large accumulations of detrital organic material and relatively little of the organic $\mathrm{C}$ is in the mineral soil.

The approach of studying gradients is not without drawbacks. It is challenging to locate clean environmental gradients, meaning gradients with a minimum of confounding variability. For example, one of the problems in climate-gradient studies is that climate and vegetation cannot always be separated as independent variables across landscapes. In Hawai'i, the same tree species, Metrosideros polymorpha, dominates native forests in young to mature and mesic to wet sites, and this is one reason that Hawai'i has proven a rich location for gradient studies. For research relevant to anthropogenic environmental change, a fundamental drawback of most 
gradients is that they reflect gradual or long term influences rather than rapid or transient responses (Dunne et al. 2004). For example, relationships between soil C stocks and vegetation or climate across natural gradients have taken shape over relatively long time scales. The response of a soil to a rapid change in vegetation or climate may not be of the same magnitude or even in the same direction as that predicted from natural gradients. For example, the difference in soil $\mathrm{C}$ stored at two elevations with a $3^{\circ} \mathrm{C}$ temperature difference may be quite different from the change in $\mathrm{C}$ stocks that would occur if the higher elevation site warmed by $3^{\circ} \mathrm{C}$ in a hundred years.

Experimental manipulations are useful not only for controlling variables of concern but also for investigating short term responses to environmental change. They, too, have drawbacks however. Field experiments may not run for long enough or encompass a large enough area to predict long term effects of environmental change. For example, the relationship of $\mathrm{C}$ stock to soil temperature was negative during the first nine years of experimental warming in a montane meadow but positive along a local climate gradient. The $\mathrm{C}$ decline observed in the experiment appears to have been a transient, process-rate response because concurrent changes in plant litter quality may lead to increases soil C storage (Saleska et al. 2002). Another limitation of ecological experiments is that they tend to use step changes in variables rather than matching the gradual rate of expected changes (Shaver et al. 2000). Results from a suite of ecosystem warming manipulations in Europe and North America indicate that (1) the same temperature change can elicit different responses, depending on the initial climate and biogeochemical conditions of the system; (2) temperature affects ecosystems rapidly via process rates and more slowly via species composition and tissue chemistry; and, as a result (3) the magnitude and direction of the response can change over time. 
Finally, processes operating at larger spatial scales may control the storage of $\mathrm{C}$ in soils. Fire, for example, is as important a loss mechanism as decomposition for organic $\mathrm{C}$ in thick detrital layers in boreal forests (Harden et al. 2000). For fire-prone regions, the net status of the land surface as a $\mathrm{C}$ sink or source depends as much on the area burned in a given year as on the responses of decomposition rates to weather variability in unburned areas.

\section{TURNOVER TIME AND DYNAMICS OF SOIL ORGANIC MATTER}

The chapter up to now has focused on the amount of $\mathrm{C}$ stored in soils. However, knowing the amount of organic $\mathrm{C}$ in soil provides little insight into its roles in ecosystem function or atmospheric feedbacks. For example, a large SOM reservoir that is extremely stable may provide little in the way of plant-available nitrogen and may respond slowly to climate change. It is thus important to understand not only how much $\mathrm{C}$ is stored in a reservoir, but also how rapidly the $\mathrm{C}$ cycles. This is not a simple proposition, however, as SOM is a complex mixture of compounds that cycle along a continuum of time scales from minutes to tens of thousands of years. Segregating SOM into discrete reservoirs with different turnover times, and understanding their relationship to biotic and soil conditions, is one of most important challenges for biogeochemical research today. This section summarizes some approaches and observational constraints for characterizing $\mathrm{C}$ dynamics in soils.

To lay the foundation for the following section on metrics, consider that the decomposition flux from soil is a function of the soil C stock and its decay rate. More strictly speaking, decomposition of a homogeneous reservoir is treated as a linear, donor-controlled processmeaning that the amount of $\mathrm{C}$ decomposed is the product of the $\mathrm{C}$ stock $\left(C, \mathrm{~g} \mathrm{C} \mathrm{m}^{-2}\right)$, a decomposition rate constant $(k, \mathrm{y})$, and the time interval $(\Delta t, \mathrm{y})$. The change in soil $\mathrm{C}$ stock between one time point and the next $(\mathrm{d} C / \mathrm{d} t)$ is the difference between the plant inputs $(I)$ and 
decomposition outputs $(k C)$ over that period, or using the symbols in Appendix 2: $d C / d t=I-k C$ where $t=$ time $(\mathrm{y})$ and $I=\mathrm{C}$ inputs $\left(\mathrm{g} \mathrm{C} \mathrm{m}^{-2} \mathrm{y}^{-1}\right)$. The other concept we use frequently is turnover time $(\tau)$, which is simply the reciprocal of the decomposition rate constant $(\tau=1 / \mathrm{k})$. At steady state $\tau=\mathrm{I} / \mathrm{C}$ and the soil $\mathrm{C}$ stock is the product of inputs and turnover time. The next section and Appendix 2 expand on these definitions and applications.

\subsection{METRICS OF CARBON DYNAMICS}

It is very useful to think about biogeochemical reservoirs in terms of the time constants describing their dynamics, or their mixing, transport, and age. Several terms are used to describe these time constants. Rodhe (1992) identifies three key terms for expressing the dynamics of cycling for geochemical reservoirs: turnover time, mean residence time, and average age; we have adopted this terminology here. Although under certain conditions these terms may be equivalent, they often differ and it is important to understand the distinctions among them.

The turnover time $(\tau)$ of a reservoir is its mixing or refresh rate, and is the time it would take for the reservoir to completely empty if there were no further inputs. For soils, it is a measure of the first-order kinetics for decay $\left(\tau_{\mathrm{o}}=1 / \mathrm{k}\right)$. At steady state (i.e., when inputs equal losses), it is calculated as the inventory divided by the total inputs (or total outputs) to the reservoir. To calculate the turnover time for a soil $\mathrm{C}$ reservoir at steady state, we would divide the mass of SOM $(C)$ by the total carbon fluxes $(S)$ from the reservoir or $\tau_{\mathrm{o}}=C / S$. Fluxes would include decomposition to $\mathrm{CO}_{2}$ and leaching of dissolved organic.

The average residence time (also, mean residence time; $\tau_{\mathrm{r}}$ ) of $\mathrm{C}$ in the reservoir is the average time spent in the reservoir by individual $\mathrm{C}$ atoms when they leave the reservoir (as if 
they were polled on their way out). Finally, the average age $\left(\tau_{\mathrm{a}}\right)$ of $\mathrm{C}$ atoms in the reservoir is the average time spent in the reservoir by all the atoms currently in the reservoir.

The distinction between these concepts is illustrated by the population of a country: the average age of the population might be 40 years while the mean residence time, or life expectancy, might be twice that value. Human populations are not a simple case for illustrating the concept of turnover time as we described it above, however, because they are not homogeneous in that all members do not have an equal probability of leaving at any time. If this population were homogeneous with respect to mortality and at steady state, turnover time would be the population divided by the number of members who die each year (the stock divided by the flux out).

In the simple scenario of a homogeneous SOM at steady state, the turnover time, mean residence time, and average age of organic matter in the reservoir are equal $\left(\tau_{\mathrm{o}}=\tau_{\mathrm{r}}=\tau_{\mathrm{a}}\right)$. The assumption of steady state is often reasonable for mature, undisturbed ecosystems and many papers use the terms turnover time and residence time interchangeably. However, this is rarely accurate because, not only are many studies looking at non-steady state situations, but because the assumption of homogeneity in SOM is not commonly observed. In fact, it is rarely the case that all the $\mathrm{C}$ in a bulk soil sample will be homogenous with respect to turnover (i.e., all $\mathrm{C}$ turning over at the same rate). It is thus recommended to divide SOM, physically or virtually, in pools that can be treated as homogeneous. Otherwise, estimates of turnover time may be misleading (Figure 6).

For example, Raich and Schlesinger (1992) calculated the turnover time for C in soils using $\mathrm{C}$ inventory (to $1 \mathrm{~m}$ depth, and including surface litter) divided by the $\mathrm{CO}_{2}$ emission observed for the same ecosystem (corrected assuming $\sim 30 \%$ was root respiration and $\sim 70 \%$ from organic 
matter decomposition). The turnover times they calculate ranged from $10 \mathrm{y}$ in tropical grasslands to $\sim 500 \mathrm{y}$ for tundra and wetland environments, with a global average of $32 \mathrm{y}$.

Yet, radiocarbon measurements of SOM find that the average age of soil $\mathrm{C}$ is several hundreds to thousands of years in temperate and some tropical systems. The apparent contradiction with Raich and Schlesinger's results may be explained if most of the flux of $\mathrm{CO}_{2}$ from the soil is derived from decomposition of "young" carbon, whereas much of the $\mathrm{C}$ residing in the soil is stabilized and decomposing only very slowly. In other words, instead of a large C reservoir with 10-year turnover in tropical grasslands, there is likely a small reservoir of annualcycling organic matter and a much larger one cycling on time scales of several decades to a century. The distinction is important if we want to predict the rate and magnitude of the response of these grassland soils to disturbances like management or climate change. More generally, quantifying decomposition rates and residence times for $\mathrm{C}$ in different compounds and locations in the soils is an important research area.

What are the time scales of soil carbon cycling? As stated above, soil organic matter cycles on a continuum of time scales. A continuous distribution of decomposition rates, however, is difficult to constrain using field or laboratory measurements. There is general agreement that the distribution of SOM decomposition rates tends to cluster at three very different time scales: subannual, decadal-century, and longer. Root exudates, microbial cell contents and some fresh litter compounds decompose on time scales of hours to months to years, and are referred to as the “active pool.” Highly stabilized organic matter, typically associated with mineral surfaces or very stable aggregates, persists in soils for thousands of years and is often referred to as the "passive" or "millennial cycling" C pool. The remaining "intermediate" or "slow" C has turnover times in the range of decades to centuries, and may consist of structural components of plants 
more resistant to decay, or organic compounds that have been stabilized by their association with soil minerals or aggregate structures. While these pools are broad categories with many exceptions, they have proven useful for many kinds of experimental and modeling studies (Figure 7). We will divide our discussion of $\mathrm{C}$ dynamics by the time scale involved in decomposition.

\subsection{OBSERVATIONAL CONSTRAINTS FOR DETERMINING SOIL CARBON DYNAMICS}

No single satisfactory method yet exists by which to separate soil $\mathrm{C}$ from the complex soil matrix into discrete components with different turnover times. Instead, soil C dynamics are deduced using many constraints, including: physical and chemical fractionation of organic matter, field and laboratory decomposition studies, measures of $\mathrm{C}$ fluxes into and out of the soil, measurements of ${ }^{14} \mathrm{C}$ in soils sampled at various times before and after the peak of atmospheric

nuclear weapons testing, changes in the ${ }^{13} \mathrm{C}$ content of SOM following a vegetation change from plants with $\mathrm{C}_{3}$ to $\mathrm{C}_{4}$ photosynthetic pathways, additions of ${ }^{13} \mathrm{C}$ and ${ }^{14} \mathrm{C}$ tracers, and measurements of changes in the total amount of $\mathrm{C}$ in soils of different age or following disturbance. Each of these approaches is suitable for studying different time scales of soil cycling, and combining two or more often forms the most powerful means of elucidating $\mathrm{C}$ dynamics. Here we discuss the use and limitations of some of the most common approaches.

\subsubsection{Litter Decomposition Experiments}

The rate of mass loss of fresh plant litter may be used to estimate litter decomposition rates, assuming first order kinetics:

$$
\mathrm{d} M / \mathrm{d} t=-k M ; k=-t^{-1} \ln \left(M_{t} / M_{0}\right)
$$


where $M_{0}$ is initial litter mass and $M_{t}$ is mass at time $t$ after deployment. Unless one is tracking isotopically labeled material (see next section), this method is complicated by the need for a litter-containment system that keeps litter fragments in while allowing soil fauna to move in and out (e.g., Harmon et al. 1999), which may create artifacts. Nevertheless, litter bags are a widely accepted method of quantifying and comparing litter decay rates.

Most litter-bag experiments in temperate and tropical ecosystems show relatively rapid initial rates of loss, followed by slower decomposition of the remaining, more recalcitrant compounds (with the absolute rates depending on climate, substrate properties, soil fauna, and soil properties) (Moore et al. 2007; Parton et al. 2007; Zhang et al. 2008). Moreover, experiments using carbon isotopes to follow specific decomposition pathways (Osono et al. 2008) have shown that, while most of the plant litter $\mathrm{C}$ decomposes rapidly, a portion is incorporated into components that are stable and persist for many years (Hanson et al. 2005). Therefore, it should not be assumed that labile plant litter, or plant litter with rapid rates of initial degradation will also produce SOM with rapid turnover rates. Indeed, C dynamics in aboveground litter vs. mineral soil may bear little resemblance, reflecting the effects of microbial transformations as well as fundamental differences in biotic and abiotic conditions. In fact, although litter decay rates for different plant functional types have been used to parameterize organic matter turnover in most ecosystem soil C models, the link between litter quality and SOM turnover is not well established.

\subsubsection{Laboratory Incubations}

Laboratory incubations provide a controlled environment for characterizing and comparing $\mathrm{C}$ and nutrient dynamics in isolated soils. While subject to artifacts, they do provide one way to quantify the amount of fast-turnover C in soils (Paul et al. 2001). Most often, soils are incubated 
in jars (Stotzky 1965; Hart et al. 1994) or microlysimeters (Nadelhoffer 1990). Incubations have been used to estimate $\mathrm{C}$ mean residence times (Torn et al. 2005; Paul et al. 2006) and stability (Whalen et al. 2000; Swanston et al. 2002), interactions of SOM and various nutrients (Zak et al. 1993; Swanston et al. 2004; Torn et al. 2005), and the influence of temperature and moisture on SOM decomposition (Reichstein et al. 2005; Dutta et al. 2006). However, the isolation that allows for controlled conditions also introduces artifacts. Specifically, the altered microclimate, soil disturbance, and lack of continued plant inputs associated with incubations cause changes in substrate quality, microbial communities, and decay rates. We suggest that while incubations are useful for comparative and process-level investigations it is generally inadvisable to extrapolate rates from the lab to ecological settings.

\subsubsection{Soil Respiration}

Soil respiration, $\mathrm{CO}_{2}$ flux from soils to atmosphere, is a fundamental flow in the terrestrial carbon cycle and the primary way that carbon moves from ecosystems back to the atmosphere. Soil respiration is one of the largest fluxes in the global carbon cycle, at $50-80 \mathrm{Pg} \mathrm{C} \mathrm{y}^{-1}$ (Raich and Schlesinger 1992; Potter et al. 1993; Schimel 1995). Since the annual exchange of C between the soil and atmosphere is so large (by comparison, fossil fuel use released less than 8 Pg C in 2007), interannual variability in soil respiration is an important source of variation in the rate of increase in atmospheric $\mathrm{CO}_{2}$ (Trumbore et al. 1995). In most ecosystems, soil respiration makes up $>50 \%$ of total ecosystem respiration. To estimate global patterns, consider that at steady state total ecosystem respiration roughly equals gross primary productivity, and heterotrophic respiration roughly equals net primary productivity (because at steady state the flux of plant inputs is matched by the flux of decomposition). Soil respiration thus varies with 
latitude, from $80 \mathrm{~g} \mathrm{C} \mathrm{m}^{-2} \mathrm{y}^{-1}$ in deserts to 800-2000 $\mathrm{g} \mathrm{C} \mathrm{m}^{-2} \mathrm{y}^{-1}$ in tropical forests (Raich and Potter 1995; Raich and Schlesinger, 1992; Schlesinger, 1977; Trumbore et al., 1995).

The most common method of measuring soil respiration is to place a chamber over the soil and measure the change in headspace $\mathrm{CO}_{2}$ concentration. This may be done rapidly and accurately by using a chamber connected to a portable infrared gas analyzer, such as that made by LI-COR, Inc. For longer incubation times of 15-60 minutes, syringe samples of headspace air can be collected and analyzed with a gas chromatograph. For a continuous 24-hour measurement, headspace $\mathrm{CO}_{2}$ can trapped in soda lime in the chamber. The longer incubation times likely create artifacts in the flux measurements. Eddy covariance methods measure net ecosystem carbon exchange (the difference between all photosynthesis and respiration in their footprint) and provide data to constrain models of soil respiration. If they are located over a bare field or below the plant canopy they measure soil respiration directly.

Despite its importance in ecosystem $\mathrm{C}$ fluxes, soil respiration has limitations as a constraint on SOM turnover for two main reasons. First, it is difficult to partition soil respiration into its two sources: (1) decomposition of SOM by microbes (heterotrophic respiration) and (2) respiration from live plant roots (autotrophic respiration) (Kuzyakov 2006). As a result, an increase in soil respiration may indicate not only an increase in SOM decomposition but also an increase in root respiration. Second, it is likely that in most soils only a small fraction of total SOM contributes to heterotrophic respiration. As a result, respiration measurements provide information about the dynamic fraction of SOM (particularly when combined with ${ }^{14} \mathrm{C}$ measurements of respiration) but do not provide information about the large, stable pools unless they are destabilized and contribute to respiration (detectable with ${ }^{14} \mathrm{CO}_{2}$ respiration measurements). Attributing the sources of respiration from different SOM reservoirs, which may 
respond differently to climatic variables, is not currently attainable through $\mathrm{CO}_{2}$ flux measurements alone. Changes in atmospheric $\mathrm{CO}_{2}$ and climate will affect autotrophic and heterotrophic respiration in different ways (Kuzyakov 2006). To use soil respiration measurements to help understand the effects of climate change on SOM turnover vs. net primary productivity (NPP) in situ, respiration must be partitioned.

Approaches to partitioning soil respiration typically involve some combination of (1) physically separating respiration sources (e.g., separating roots from soil and measuring respiration of roots and root-free soil), (2) stimulating or suppressing respiration sources (e.g., adding glucose to stimulate microbes or trenching or girdling to reduce root respiration), and/or (3) isotopically labeling respiration sources (e.g., pulse labeling of whole plants or growing $\mathrm{C}_{3}$ plants in soil produced under $\mathrm{C}_{4}$ vegetation, combined with measuring the isotopic content of soil respiration) (Kuzyakov and Larionova 2005). Most of these approaches have been used in laboratory or greenhouse experiments rather than in situ. In both the lab and field, it is difficult to avoid disturbance of plant carbon flows or soil structure that unintentionally alter microbial activity and $\mathrm{CO}_{2}$ flux rates. Nevertheless, these techniques provide valuable constraints on relative fluxes and the effects of environmental variables on them.

\subsubsection{Isotopic Tools: Tracers}

Carbon has three stable or long-lived isotopes: $98.9 \%$ of earth's $\mathrm{C}$ is ${ }^{12} \mathrm{C}, \sim 1.1 \%$ is ${ }^{13} \mathrm{C}$ (a stable isotope) and about 1 in $10^{-12}$ carbon atoms is ${ }^{14} \mathrm{C}$. By enriching or depleting the ratios of the rare isotopes in plants, plant litter, or other organic material put in soil, it is possible to follow the pulse of altered isotopic ratios (and the carbon compounds they were associated with) as they move through the system. 
Carbon isotopic tracers can be an effective means of characterizing $\mathrm{C}$ reservoirs that cycle on sub-daily to decadal time scales. Because of the high cost of isotopically enriched material and the logistical difficulty of labeling large trees or large areas, these studies typically take place in fairly small plots. A notable exception are the free-air $\mathrm{CO}_{2}$ enrichment (FACE) experiments, which maintain elevated levels of atmospheric $\mathrm{CO}_{2}$ in open-air sites that are up to $30 \mathrm{~m}$ in diameter. If the elevated $\mathrm{CO}_{2}$ is supplied by a fossil source, the elevated- $\mathrm{CO}_{2}$ treatment atmosphere is isotopically depleted in both ${ }^{13} \mathrm{C}$ (approximately $\delta^{13} \mathrm{C}$ of $-21 \%$ as compared to $8 \%$ ) and ${ }^{14} \mathrm{C}\left(\Delta^{14} \mathrm{C}\right.$ of $-1000 \%$ as compared to approximately $-60 \%$ ). For example, Jastrow et al. (2005) analyzed the depleted ${ }^{13} \mathrm{C}$ pulse in SOM fractions to show accumulation of SOM in elevated $\mathrm{CO}_{2}$ treatments at several FACE sites. Another exception is the Enriched Background Isotope Study (EBIS) at Oak Ridge National Laboratory in Oak Ridge, Tennessee, USA (Trumbore et al. 2002). EBIS investigators used a combination of a stand-level radiocarbon enrichment and a reciprocal litter transplant from a forest stand with litter that had nearbackground ${ }^{14} \mathrm{C}$ levels, to partition sources of soil respiration (Cisneros-Dozal et al. 2006) and investigate SOM dynamics (Hanson et al. 2005; Swanston et al. 2005).

\subsubsection{Natural Abundance Stable Carbon Isotopes $\left({ }^{13} \mathrm{C}\right)$}

There are trends in ${ }^{13} \mathrm{C}$ of plant, litter, and organic constituents in soil that can be used to investigate carbon cycling, but to date the trends have proven too subtle, variation too high, or mechanisms too poorly understood to exploit these patterns definitively. The $\delta^{13} \mathrm{C}$ of plant litter and particulate SOM is typically close to that of the plant source, while mineral-associated SOM is often $1-3 \%$ higher (more enriched). Within the profile, the $\delta^{13} \mathrm{C}$ of bulk soil increases by 1 $3 \%$ with increasing depth and decreasing particulate SOM. Comparisons of $100 \mathrm{y}$ old and modern soil profiles shows that the increase in ${ }^{13} \mathrm{C}$ with depth is not due to fossil fuel effects 
(Torn et al. 2002), but there is ongoing discussion regarding whether these trends are caused by microbial discrimination or selective preservation of plant compounds (Dijkstra et al. 2006; Mikutta et al. 2006) and resolution of these questions may be difficult using only natural abundance stable isotopes and non-manipulated systems.

Due to differences in their photosynthetic pathways, $\mathrm{C}_{3}$ and $\mathrm{C}_{4}$ plant biomass have different ${ }^{13} \mathrm{C} /{ }^{12} \mathrm{C}$ ratios $\left(\mathrm{C}_{3}: \delta^{13} \mathrm{C} \approx-27 \%\right.$; $\mathrm{C}_{4}: \delta^{13} \mathrm{C} \approx-13 \%$; Still et al. 2003). Where a vegetation change from $\mathrm{C}_{3}$ to $\mathrm{C}_{4}$ plants (or vice-versa) has occurred, the rate of change of ${ }^{13} \mathrm{C} /{ }^{12} \mathrm{C}$ ratios in SOM will give an idea of the turnover time of SOM (Balesdent et al. 1988; Veldkamp 1994). This method has been used most commonly in tropical pastures where $\mathrm{C}_{4}$ grasses have replaced $\mathrm{C}_{3^{-}}$ dominated forest, and in the agricultural sites where $\mathrm{C}_{4}$ maize has replaced native $\mathrm{C}_{3}$ forest. While generally a very useful method, there are two main limitations to mention: (1) it cannot be used to study soils that have not undergone a vegetation change; and (2) it requires careful measurement of $\mathrm{C}$ inventory changes in disturbed versus undisturbed soils. These attempts are complicated by plowing, discing, and/or erosion of the pasture soils, as well as inherent uncertainty in bulk density determinations.

\subsubsection{Radiocarbon}

Radiocarbon $\left({ }^{14} \mathrm{C}\right)$ is unstable, with a half-life of 5,730 y, and decays by emission of an electron to form ${ }^{14} \mathrm{~N}$. It is continuously produced in the upper atmosphere by interactions of highenergy cosmic rays with the upper atmosphere. The ${ }^{14} \mathrm{C}$ is oxidized to ${ }^{14} \mathrm{CO}_{2}$ within a few weeks, and mixed into the troposphere (the lower, well-mixed part of the atmosphere), where it is taken up by plants during photosynthesis and exchanges with the surface waters of the ocean.

If a $\mathrm{C}$ reservoir ceases to actively exchange ${ }^{14} \mathrm{C}$ with the atmosphere, the ${ }^{14} \mathrm{C}$ content of the reservoir will begin to decrease because of radioactive decay. This is useful for studying very 
stable $\mathrm{C}$ pools in soils, since they reside long enough for significant decay of ${ }^{14} \mathrm{C}$ to occur. In this case, the more ${ }^{14} \mathrm{C}$-depleted a soil fraction is, the slower the turnover of the $\mathrm{C}$ is (even if the soil fraction also contains some faster-cycling components; Mikutta et al. 2006; Sollins et al. 2006). The longest time scales that can be addressed with ${ }^{14} \mathrm{C}$ in this way are on the order of 60,000 $\mathrm{y}$.

Atmospheric thermonuclear weapons testing, which peaked in 1963, approximately doubled the amount of ${ }^{14} \mathrm{C}$ in the atmosphere (Figure 8). Atmospheric ${ }^{14} \mathrm{CO}_{2}$ levels have been decreasing rapidly since then, because of atmospheric exchange with terrestrial and oceanic $\mathrm{C}$ reservoirs. This "bomb" ${ }^{14} \mathrm{C}$ spike provides a global isotopic tracer for the $\mathrm{C}$ cycle, although still several orders of magnitude below levels of ${ }^{14} \mathrm{C}$ used in most small-scale ${ }^{14} \mathrm{C}$-tracer studies. The amount of bomb ${ }^{14} \mathrm{C}$ found in SOM provides a direct measure of the amount of fast-cycling (active+slow) SOM. The most straightforward application is to compare the ${ }^{14} \mathrm{C}$ content of SOM sampled prior to 1960 with that of contemporary samples from the same location (Trumbore 1993; Trumbore 2000). Where no archived soils are available, however, radiocarbon measurements must be combined with other observational constraints to separate the radiocarbon signature of rapidly cycling from very refractory organic matter. The time scales of $\mathrm{C}$ turnover that may be addressed using bomb ${ }^{14} \mathrm{C}$ range from $\sim 4$ to $\sim 100 \mathrm{y}$.

The ${ }^{14} \mathrm{C}$ content of soil respiration leaving the soil can be measured using trapped air from the headspace of a chamber (Dörr and Münnich 1986; Gaudinski et al. 2000). To the extent that ${ }^{14} \mathrm{C}$ reflects recently fixed $\mathrm{C}$ versus $\mathrm{C}$ fixed years-to-decades ago, ${ }^{14} \mathrm{CO}_{2}$ measurements provide a useful tool for partitioning the sources of soil respiration (autotrophic plant respiration versus heterotrophic microbial respiration) and the turnover times of the decomposing organic matter that contributes the most to soil respiration (Torn et al. 2005). Working in temperate grassland and forest, Dörr and Münnich (1986) found significant seasonal differences in the ${ }^{14} \mathrm{C}$ content of 
total soil respiration, with summer emissions dominated by recently fixed carbon, and winter fluxes by carbon fixed up to several decades previously (which likely indicates a higher proportion of autotrophic respiration in the growing season as well as seasonal changes in the substrate for decomposition).

In summary, natural abundance radiocarbon is a powerful tool because it can be used in mature and undisturbed ecosystems (as well as in younger or disturbed ones) and because it can be used to quantify turnover times across a range of time scales. In fact, it may be the only tracer for stable, or slow-cycling $\mathrm{C}$ pools. The radiocarbon content, along with additional constraints regarding, for example, the relative proportions of fast and slow cycling SOM, can be used to model turnover times. Appendices 1 and 2 contain more thorough exploration of radiocarbon methods and applications to SOM studies.

\subsubsection{Fractionation of Soil Organic Matter}

There are numerous approaches to separating SOM pools for analysis, with a corresponding number of underlying conceptual frameworks. The objective of fractionation is usually to reduce the chemical, physical, and/or C-cycling time variation in the fractions compared to the bulk soil. Nonetheless, most isolated SOM fractions are operationally defined and remain a mixture of heterogeneous compounds from multiple sources. The near-term challenge is not to find a single, universal method that will characterize all SOM pools in all soil types, but instead to understand what kind of information is provided by each method for the scientific questions of interest. The most common methods of fractionating SOM are chemical (humic/fulvic separation, acid hydrolysis), density, size, and aggregate.

Humic and fulvic acids are isolated by extracting the soil with alkali, thus solubilizing the acids from the humin, and then treating the extract with acid to separate the humic and fulvic 
acids. Ideally, this method separates SOM by chemical characteristics, in which the humic fraction contains compounds with a higher degree of polymerization, molecular weight, and C and oxygen concentration compared to those in the fulvic fraction (e.g., Stevenson 1994). As such, these fractions may provide "signatures" for soils, perhaps varying with factors such as vegetation and management (Miglierina and Rosell 1995). Chemical separation methods have significant drawbacks. Primarily, the harsher treatments can form new compounds as well as solubilize and extract them. Extraction with $\mathrm{NaOH}$ can separate some lignin-derived aromatic $\mathrm{C}$, depositing it into the humic acid while the remainder is left in the humin (Kögel-Knabner et al. 1991). Most polysaccharides would presumably reside in the fulvic fraction. Thus, although these $\mathrm{C}$ structures are related spatially and biologically in the soil, chemical fractionation procedures can separate them into several fractions, potentially obscuring their connected roles in soil $\mathrm{C}$ cycling. Another common chemical separation is acid hydrolysis, used to isolate N-rich compounds (including proteins and nucleic acids), polysaccharides, and other chemically labile SOM from acid resistant material such as aromatics and long-chain aliphatics (Paul et al. 2001). More recently, ultraviolet radiation and chemical $\left(\mathrm{H}_{2} \mathrm{O}_{2}\right.$ or $\left.\mathrm{NaOCl}\right)$ methods have been used to oxidize some organic matter and leave behind less reactive, and radiocarbon-older, organic residues (Krull et al. 2006; Mikutta et al. 2006; Zimmermann et al. 2007). In two comparisons, $\mathrm{NaOCl}$ appears to cause less mineral alteration and yield an older $\mathrm{OM}$ fraction than does $\mathrm{HCl}$ (Mikutta et al. 2006; Zimmermann et al. 2007). These approaches use chemical reactivity of organic matter as a proxy for readiness to microbial degradation, rather than attempting to separate material of different chemistry per se.

Physical soil fractionation methods such as density, size, and aggregation aim to isolate pools of SOM based upon their degree of organomineral interaction, the extent of protection 
within aggregates, and the size and location of the aggregates. Density fractionation takes advantage of the differences in density between particulate organic matter and mineralassociated organic matter. The basic approach is that a light fraction is floated on a dense liquid and the denser, or heavy fraction, sinks (Strickland 1987; Sollins et al. 1999). The light fraction is typically less degraded, more plant-like, and of more recent origin than the $\mathrm{C}$ in the mineralassociated heavy fraction (Gregorich et al. 1996; Trumbore and Zheng 1996). Golchin et al. (1994a) modified this technique to separate the 'free', unprotected light fraction first, then disrupted aggregates to separate the "occluded", aggregate-protected light fraction from the dense fraction. Radiocarbon measurements show that the occluded light fraction can have a slower turnover time than the heavy fraction (Rasmussen et al. 2005; Swanston et al. 2005). The heavy fraction can be further separated by increasing density, generally yielding older, but smaller, organomineral pools (Golchin et al. 1994b; Sollins et al. 2006). There is evidence that aggregate dispersion may redistribute $\mathrm{C}$ and $\mathrm{N}$ between fractions (Cambardella 1994; Baisden et al. 2002), and some $\mathrm{C}$ and $\mathrm{N}$ (1-15\%) is typically lost during these procedures (Swanston et al. 2004; Crow et al. 2007; Castanha et al. 2008). However, density separation does produce fractions with distinct $\mathrm{C}, \mathrm{N}$, and isotopic composition, and appears to reveal the trends in mineral-associated SOM as well as provide some information about protection of particulate organic matter in macro- and microaggregates (Golchin et al. 1994a; 1994b).

Particle size fractionation is based on the concept that as organic matter is degraded and interacts with minerals, particle size decreases (Tiessen and Stewart 1983a; Christensen 1992). Variations in size-fraction methods exist (e.g., Christensen, 1992), but soils are typically dispersed sonically, by shaking with glass beads, or chemically with hexametaphosphate, and the resulting soil slurry is passed through a series of decreasing sieve sizes and centrifuged to isolate 
fine fractions. Although there are some trends with particle size, it is also evident that $\mathrm{C}$ pools separated by size are composed of multiple, chemically protected or biochemically recalcitrant pools with differing residence times that may be classified as a function of origin, chemical composition, and mineralogical interactions (Schmidt and Kogel-Knabner 2002; Kiem and Kogel-Knabner 2003). Size separation can be particularly useful in separating organic matter into distinctive chemical pools in organic horizons, in other words where no mineral stabilization is occurring, with material $<63$ micron of predominantly microbial origin and larger sizes made up of plant material (Grandy and Neff 2008).

The goal of aggregate-based soil fractionation is to isolate $\mathrm{C}$ pools according to their location in different soil physical structures, based on a conceptual model of stabilization of C inputs in microaggregates that cycle with macroaggregates (e.g., Oades 1984; Golchin et al. 1994b; Jastrow et al. 1998; Six et al. 2000a; Six et al. 2000b). Based in part on work by Golchin et al. (1994b) and Cambardella and Elliot (1994), Six et al. (2000a) developed a fractionation scheme designed to separately isolate SOM found inside and between aggregates of different sizes and stabilities. Physical isolation of intact microaggregates, including those located within macroaggregates, followed by their dispersion provides quantitative information for several process steps related to SOC cycling. Unfortunately, this method does not reduce the problem of losing $\mathrm{C}$ and $\mathrm{N}$ during the separation and rinsing process (Chan 2001; Moran et al. 2005).

\subsubsection{Microbial Fractionations}

Microbes ultimately determine what organic compounds will be metabolized in soils. Trumbore (2000) demonstrated that $\mathrm{C}$ respired from soils is younger than the mean age of $\mathrm{C}$ in organic matter. Measures of radiocarbon in classes of phospholipid fatty acids from microbial cell walls, however, show that microbes consume $\mathrm{C}$ substrates with a range of ${ }^{14} \mathrm{C}$ ages. Similar 
results have been observed with ${ }^{13} \mathrm{C}$ and ${ }^{15} \mathrm{~N}$ labeled litter added to soil (Bird and Torn 2006). Combining microbial biomarkers with isotopic analysis is a promising technique but is beyond the scope of this chapter to cover adequately.

\subsection{SOIL CARBON STOCK AND BULK DENSITY}

The stock of organic matter in soil is one of the most fundamental constraints on estimates of turnover time and tests for models that predict storage or turnover time. The amount of organic carbon stored in a soil profile is calculated from measurements of $\mathrm{C}$ density and bulk density (BD) by horizons or depth intervals, $i$, as follows:

$$
\text { C inventory }\left(\frac{g C}{c^{2}}\right)=\sum_{h o r i z o n=i}^{n} \text { Bulk Density }_{\mathrm{i}}\left(\frac{g \text { soil }}{\mathrm{cm}^{3}}\right) \times \operatorname{Carbon}^{\text {Density }}\left(\frac{g C}{g \text { soil }}\right) \times \operatorname{depth}_{\mathrm{i}}(\mathrm{cm}) \times\left(1-\text { fr gravel }_{i_{i}}\right.
$$

The well established methods for measuring and reporting $\mathrm{C}$ density need no elaboration here. Bulk density, the dry weight of a known volume of soil, including pore space, is a simple concept that is difficult to measure. Bulk density values can vary by a factor of 4 depending, for example, on soil OM content, depth, and compaction. Because it varies and because measurement is difficult to do precisely, the largest uncertainties in determining $\mathrm{C}$ stock in a soil profile usually come from estimates of bulk density and the volume of soil that is gravel. The last term in the equation above is a correction for stones and gravel greater than $2 \mathrm{~mm}$ in diameter, also called the coarse fraction or gravel fraction. It is difficult to reproducibly collect a precise volume of soil and in many studies bulk density simply has not been measured at all.

In addition to expressing soil $\mathrm{C}$ stocks on an areal basis, it may be preferable, particularly for comparisons of $\mathrm{C}$ stocks due land use changes that alter bulk density, to express soil C stocks on an equivalent mass basis. This approach, nicely explained by Ellert et al. (2001), samples to a 
depth giving a constant mass of soil at all locations or time points, rather than a constant depth of soil. Calculating the required depth requires bulk density measurements.

There are several new in situ soil carbon measurement techniques undergoing field testing. Some devices, such as those using a neutron generator, measure total $\mathrm{C}$ atoms to a known depth and as a result do not require a bulk density measurement (L. Wielopolski, personal communication). In addition, such in-situ and non-invasive techniques would allow the same location to be measured repeatedly. However, for the time being, and likely for many applications in the future, the importance of carefully measuring bulk density cannot be overstated.

Large plant fragments and organic mats are often excluded from estimates of soil C stocks, either during sample collection or during sieving at $2 \mathrm{~mm}$. The traditional focus in soil science on the 'fine soil,' however, is not adequate in the context of carbon management, where a complete accounting of organic carbon is desirable. Researchers are adapting to this expanded perspective by developing new protocols and expectations for the reporting of soil characteristics.

\section{IMPORTANT CONTROLS OF SOIL CARBON DYNAMICS}

Definition of three terms that are commonly used interchangeably but nonetheless have distinct meanings will aid our discussion of the controls of soil $\mathrm{C}$ dynamics. In the most general sense, a process is a series of steps leading to a result; in the context of carbon cycling, the result is the stabilization or destabilization of carbon. A mechanism is the crucial step in the process, or the physicochemical condition or transformation that most distinctly results in carbon stabilization or destabilization. A control is something that exerts an exceptionally strong influence on a process, rendering mechanisms more or less effective. 
Soil $\mathrm{C}$ dynamics are the integration of myriad processes leading to stabilization or destabilization of SOM. Sollins et al. (1996) describe SOM cycling within the context of proximal and distal influences; that is, mechanisms that have an immediate influence on $\mathrm{C}$ stability and flux (e.g., molecular recalcitrance, mineral and organic interactions, and accessibility) ranging to controls with a distal and more general influence (e.g., the state factors, 'cloprt'). This conceptual hierarchy is a useful framework in which to chart the relationships of the numerous influences on soil $\mathrm{C}$ turnover. One subtlety is that a proximal influence (mechanism) is not necessarily the dominant factor in C stabilization, nor is a distal influence necessarily a minor factor. We suggest that there is no universally dominant mechanism or control on SOM dynamics. Instead, we consider different controls, and what factors make a particular mechanism more important or effective in one place but not another.

\subsection{MECHANISMS OF STABILIZATION}

A physical or chemical condition that renders SOM less susceptible to alteration or transport (i.e., more stable) is a mechanism of stabilization. The assumed mode of alteration is often microbial activity, although this is not always explicit. A great deal of thought has gone into defining and comparing the dominant mechanisms that affect $\mathrm{C}$ stability, and organizing them into a limited number of broad categories (Sollins et al. 1996; Baldock and Skjemstad 2000; Krull et al. 2003; Lützow et al. 2006). Additionally, researchers have sought to identify the dominant mechanisms of long-term stabilization, leading some to focus on the inherent molecular recalcitrance of organic molecules (Krull et al. 2003), and others on mineral interaction and protection as the fundamental controls (Van Veen and Kuikman 1990; Lützow et al. 2006). Here we describe several categories of stabilization mechanisms, largely adapted from Sollins et al. (1996), and place them within the context of climate, ecology, and management. 


\subsubsection{Recalcitrance}

We use the term 'recalcitrance' to refer specifically to the inherent molecular characteristics of SOM that contribute to resistance to microbially mediated degradation within a soil environment (Sollins et al. 1996). Aliphatic (e.g., lipids, waxes) and aryl (e.g., charcoal) compounds tend to have the longest turnover times in many soils (Hamer et al. 2004; Preston and Schmidt 2006), and are often considered to be more recalcitrant than other organic compounds. Attention to the compounds that have been labeled as recalcitrant in different soils in different ecosystems, however, suggests that molecular characteristics may not convey inherent (i.e., universal) stability, but rather recalcitrance may be more context-specific: (1) whether a particular turnover time is considered "stable" depends on the cycling rates of other SOM pools in the same soil or region and (2) the same compounds may be more or less recalcitrant than each other in different environments, depending on controls. A recent review concluded that there is increasing evidence that selective preservation of plant compounds is not important for soil C storage (Lutzow et al. 2008). Black carbon, organic matter transformed by pyrolization, remains a candidate for recalcitrance. Comparing a grassland, woodland, and subtropical rainforest in Australia, Krull et al. (2006) concluded that although the woodland and rainforest had greater aggregate and mineral protective capacity, respectively, the grassland supported a larger reservoir of more stable carbon due to frequent inputs of charcoal from regular fires. In a Russian Steppe soil, on the other hand, black carbon had a profile-total turnover time of less than $300 \mathrm{y}$, which was faster than turnover of the bulk soil organic matter. (Hammes et al., in press).

\subsubsection{Mineral associations}

Direct association between organic $\mathrm{C}$ and primary and secondary minerals in soil includes H-bonding, van der Waals forces, ligand exchange, cation bridging, and metal complexation 
(e.g., v. Lützow et al. 2006). Multiple layers of organic C may range outward from the mineral surface with decreasing strength of association, and the outer layers may thus be the most actively cycling of the mineral-stabilized C (Sollins et al. 2006; Kleber et al. 2007; Rillig et al. 2007). The cleavage of the innermost bonds may often prove energetically unfavorable, raising the possibility that it is actually mineral dissolution or evolution that results in destabilization of the SOM at the mineral surface instead of direct degradation. Along a chronosequence in Hawai'i, Torn et al. (1997) found that soil C content and radiocarbon abundance were correlated with the changing soil mineralogy. They concluded that as metastable non-crystalline minerals transition into crystalline clays that have lower surface area and charge density, their ability to stabilize SOM is reduced. In this warm, humid ecosystem, mineral association appears to be the dominant control on long-term SOM stability. For more systematic treatments of mechanisms at the mineral or root interface, see Kleber et al. (2007) and Rillig et al. (2007).

\subsubsection{Accessibility}

Physical protection that precludes microbial and enzymatic access to SOM may preserve a substrate that would otherwise be rapidly degraded. This type of protection is largely a function of soil structure, occurring primarily within meso- and microaggregates, pores with spaces or entrances too small for soil organisms or enzymes to pass (Oades 1988; Mayer et al. 2004; Strong et al. 2004). Additionally, highly tortuous diffusional paths may reduce the viability of bacterial 'foraging' using enzymes, potentially reducing the likelihood that otherwise degradable SOM is degraded (e.g., Vetter et al. 1998). The influence of aggregate protection can readily be seen in grassland soils under different regimes of physical disturbance; in agroecosystems aggregate disruption by tillage is usually the foremost cause of soil C loss (e.g. Six et al. 2002). Yet soil structure is intimately related to soil texture and mineralogy. Denef et al. (2004) looked 
at conventional tillage and no-tillage cropping systems across several soils with differing clay mineralogies. While total SOM storage and aggregate stability appeared to be associated with mineralogy, $>90 \%$ of the SOM loss related to conventional tillage in all soils was associated with a single size class of microaggregates that were isolated from water-stable macroaggregates. Direct mineral association appeared to be a dominant mechanism of long-term stabilization, but a shorter-term mechanism of stabilization was the limitation of accessibility. In these intensively managed ecosystems, the mode of field preparation can thus become a major control on $\mathrm{C}$ stabilization by influencing accessibility to occluded SOM.

\subsubsection{Biotic suppression and climatic stabilization}

Organic $\mathrm{C}$ in soils does not simply cycle; rather, $C$ is cycled by biological activity. The mechanisms described above ultimately relate to the ability of soil organisms to access and degrade SOM. However, if the organisms themselves are in some way suppressed, the low activity of the soil microbiota becomes the effective mechanism of stabilization. Biotic suppression, and consequent $\mathrm{C}$ stabilization, may thus occur through conditions such as $\mathrm{O}_{2}$ limitation (e.g., flooding), desiccation (e.g., desert environments), extreme or prolonged cold (e.g., boreal and arctic systems), nutrient imbalances (e.g. N concentration; Waldrop and Zak 2006), and excessively high or low pH (e.g., mine spoils). Some of these ecosystems have high enough NPP to result in significant SOM accumulation, such as in peat bogs (Smith et al. 2004) and boreal forests (Harden et al. 2000). A major concern about climate change is that conditions may become more favorable to microbial activity, possibly leading to destabilization of large quantities of SOM that are currently protected by conditions that suppress biotic activity (Freeman et al. 2001) and fueling positive feedbacks to global warming (Chapin et al. 2000; Kirschbaum 2000; Davidson and Janssens 2006; Davidson 2006; Torn and Harte 2006). 


\subsection{MECHANISMS OF DESTABILIZATION}

Just as mechanisms of stabilization cause greater SOM stability, mechanisms of destabilization render SOM more susceptible to alteration or transport. By definition, they in some way reduce or eliminate the efficacy of the mechanisms of stabilization (e.g., Sollins et al. 1996). The controls on destabilization typically promote disturbances that expose SOM, or otherwise foster a physical environment more advantageous to microbial or faunal degradation of SOM. In general, the factors that control (enhance) destabilization promote disturbances that expose SOM or otherwise foster a physical environment more advantageous to microbial and meso-faunal degradation of SOM. Examples of natural and anthropogenic soil disturbance include tilling (Six et al. 1999), freeze/thaw and shrink/swell cycles (Denef et al. 2001), erosion and mass wasting (Harden et al. 1999), bioturbation (Stork and Eggleton 1992), windthrow (Kramer et al. 2004), and fire (Harden et al. 2000). The degradation of a substrate can also act as a mechanism for further destabilization through the production of more labile byproducts. Degradation can be from biotic or abiotic sources, such as faunal degradation (Verhoef and Brussaard 1990), microbial degradation and extracellular enzymatic alteration (Cairney and Burke 1998), and photo-degradation (Zepp et al. 2003). As a sign of the complexity of soils, destabilization often happens concurrently with stabilization. Even as a compound is degraded or transported, some byproducts may be generated that are more stable (or become stabilized more readily) than the original compound (e.g., Wolters 2000).

\subsection{TEMPORAL AND SPATIAL SCALES OF CARBON CYCLING}

As the scale of analysis moves from centuries to years or hours, and from regions to meters or microns, the relevant controls, processes, and mechanisms also change. A dominant control at a millennial time scale may be largely irrelevant for hourly variation, just as a mechanism that 
explains patterns at the scale of a field plot may shed no light on processes at the edge of a clay micelle. In this chapter, we have tried to acknowledge the complexity of the spatial and temporal dynamics of carbon cycling by considering controls, processes, and mechanisms at a point in space within the context of time, as well as at a point in time but across spatial scales. Possible examples are numerous and generalizations prone to exception; nonetheless, we offer a few hypotheses to encourage further discussion and debate of the controls on carbon turnover.

Over large spatial scales or among biomes, climate tends to dominate $\mathrm{C}$ budgets, particularly at the extremes of temperature and moisture-for example tundra and deserts—-due to direct effects of these extremes on plant production and microbial processes. Within most temperate regions, more complex relationships among state factors, processes, mechanisms, and scale exist that are not easily generalized across the landscape. Seasonal climate extremes, such as summer drought and winter cold can exert strong controls over $\mathrm{C}$ cycling through influence on plant productivity and biotic suppression. At the field scale, vegetation and topography tend to be dominant controls by determining $\mathrm{C}$ inputs and strongly influencing hydrology at a given point in time. Over long time periods, however, mineralogy influences both vegetation and topography through soil development. In the surface soil, which receives most plant $\mathrm{C}$ inputs, accessibility and recalcitrance provide greater constraints on surface soil $\mathrm{C}$ fluxes than do mineral interactions, even though mineral interactions lead to the most stable $\mathrm{C}$. While there is less $\mathrm{C}$ deeper in the soil profile, more of the deep $\mathrm{C}$ is stabilized through mineral interactions, which become the dominant mechanism of stabilization in that part of the profile. The primary mechanisms of stabilization in the rooting zone, accessibility and recalcitrance, reflect the dynamic nature of $\mathrm{C}$ inputs and soil moisture. The relative importance of these mechanisms will vary greatly with ecosystem properties and management, accessibility being dominant except in 
regions with high char inputs. Organo-mineral interactions, especially the 'inner layer' molecules, tend to stabilize $\mathrm{C}$ for much longer time spans, 100 s to 1000 s of years, and are associated with the most stable $\mathrm{C}$ throughout the profile. At the scale of the mineral surface itself, broad mechanisms like mineral associations take on the nature of processes, and finerscale mechanisms like charge density of the mineral, polarity and structure of the molecule, and the density of the pore water, most directly result in $\mathrm{C}$ stabilization.

\section{RESPONSES OF SOIL ORGANIC MATTER TO GLOBAL ENVIRONMENTAL CHANGE}

Human activities can have profound consequences for soil carbon cycling. Climate change, nitrogen deposition, elevated atmospheric $\mathrm{CO}_{2}$ concentrations and other atmospheric changes, land use and land cover change, and altered disturbance regimes are all having increasing influence on plant productivity, soil decomposition rates, and soil carbon storage. At the most basic level, changes in soil carbon stocks and net transfer of $\mathrm{CO}_{2}$ between soil and atmosphere will depend on the balance between plant productivity and soil organic matter decomposition, and how global change factors affect these flows.

\subsection{PRODUCTIVITY AND SOIL CARBON STORAGE}

Plant productivity is determined by factors such as plant species composition, moisture, soil fertility, growing season length, and solar radiation — many of which are affected by human activities. All else equal, increases in primary productivity and production of plant tissues will lead to increases in soil $\mathrm{C}$ stock, while decreases will lead to decreases in soil $\mathrm{C}$ stock. The rate of change in soil $\mathrm{C}$ stock is determined by the difference between $\mathrm{C}$ inputs and outputs, as well as the turnover times of the soil $\mathrm{C}$, which are often not known. Here we review briefly how some 
environmental factors are expected to alter productivity and explore how the effects on stock depend on the number of soil carbon pools and their turnover times.

Elevated $\mathrm{CO}_{2}$ can enhance plant growth, albeit with uncertain efficacy and duration, while the accompanying climate change will have variable effects on NPP. Most coupled climate carbon-cycle models predict that terrestrial ecosystem productivity increases in the first half of this century due to $\mathrm{CO}_{2}$ fertilization and moderate increases in temperature, but has moderate declines after that due to more severe changes in climate (Sitch 2003; Gerten 2004; Friedlingstein 2006; Fischlin et al. 2007). For example, the productivity of intact Amazonian forests has been increasing over recent decades, variously explained by episodic disturbance and recovery dynamics, changing species distribution, $\mathrm{CO}_{2}$ fertilization, modest warming, reduced tropical cloud cover, and increased radiation (Nemani 2003; Baker 2004; Chambers and Silver 2004; Lewis 2004; Malhi and Phillips 2004; Boisvenue and Running 2006). These C gains are predicted to be transient, however, due to losses associated with escalating heating and drying trends (Malhi and Phillips 2004). More generally, in the long term, it is unlikely that plant productivity will continue to increase with increasing atmospheric $\mathrm{CO}_{2}$, due to widespread limitation of NPP by water or nutrients, and because of acclimation of plants to higher $\mathrm{CO}_{2}$ conditions.

By increasing the amount of $\mathrm{N}$ available to plants, nitrogen deposition can contribute to carbon uptake in N-limited (e.g., temperate) ecosystems (Melillo et al. 1995; Schimel 1995; Trumbore 2000) but can also lead to changes in plant species, microbial community composition, and soil pH (Boggs 2005; Silvertown 2006). Changes in vegetation allocation strategy, litter quality, and soil microbes can lead to large $\mathrm{C}$ losses belowground that more than offset C gains associated with increased aboveground productivity (Mack et al. 2004). Any 
benefits of $\mathrm{N}$-deposition are expected to reach a saturation point, after which productivity levels off, and eventually diminishes due to other nutrient limitations or increased susceptibility to stresses such as pollution, frost damage, or disease (Agren and Bosatta 1988; Aber et al. 1989). Other atmospheric pollution, such as acid rain, increased tropospheric ozone, and stratospheric ozone depletion, are all predicted to reduce NPP.

In addition to productivity, plant species composition and abundance affect soil $\mathrm{C}$ cycling through tissue chemistry and surface energy balance (i.e., the energy balance between land surface and atmosphere). The latter influences soil microclimate, while the former helps determine decomposition pathways and products. Global warming is projected to lead to largescale vegetation shifts, such as expansion of boreal forests as growing season lengthens, transition from temperate evergreen to deciduous forests due to warming, and from tropical evergreen forest to seasonal forest or to grassland due to drought stress (Fischlin et al. 2007).

If plant productivity increases without a commensurate increase in decomposition rates, more carbon will be sequestered in soil. Since decomposition is proportional to the stock of SOM, stock will build up until the efflux from decomposition reaches a level roughly equal to the higher rate of inputs. While faster-cycling $\mathrm{C}$ pools will adjust more rapidly to reach a new steady state, slower cycling pools will build up to a higher stock of $\mathrm{C}$ for the same increase in NPP. As an illustrative example, consider the world's shallow carbon stocks (1500 Pg) in equilibrium with global NPP $\left(60 \mathrm{Pg} \mathrm{y}^{-1}\right)$. The average turnover time of this $\mathrm{C}$ is estimated as $25 \mathrm{y}$ for fast cycling C (Harrison 1993) or $32 \mathrm{y}$ for all soil C to $1 \mathrm{~m}$ (Raich and Schlesinger 1992). Now stipulate for this example that $\mathrm{CO}_{2}$ fertilization and other factors increase NPP by 10 percent worldwide. The predicted change in global soil stocks will depend on the number of $\mathrm{C}$ pools and the turnover time of each pool. For this example, we compare the one-pool scenario 
considered by Harrison or by Raich and Schlesinger with a two-pool scenario illustrated in Figure 9. The initial C inventory, NPP, and bulk turnover time are the same in either case. For the one-pool soil, with $\tau=25 \mathrm{y}$, increased inputs to soils from $\mathrm{CO}_{2}$ fertilization would result in a build up of the soil C inventory to $1600 \mathrm{Pg}$ in less than $100 \mathrm{y}$. However, if 30 percent of C inputs have a 2 y turnover $(\tau=2 \mathrm{y})$ and 70 percent of $C$ inputs have a 35 y turnover $(\tau=35 \mathrm{y})$ then the new C stock would - over the course of $\sim 150 \mathrm{y}$ - build up to $2500 \mathrm{Pg} \mathrm{C}$ ! (For precise estimates on century timescales, leaching of soluble $\mathrm{C}$ and erosion should also be considered.) More generally, treating soil $\mathrm{C}$ as one pool with a simple temperature response function for global change predictions will lead to an underestimate for the short term and an overestimate for the long term.

Detecting whether global soil $\mathrm{C}$ stocks have increased in the past decades, and acted as a sink of atmospheric $\mathrm{CO}_{2}$, is very difficult due to spatial heterogeneity in soils, relatively large analytical uncertainties (especially in bulk density), and the fact that even changes of a small fraction of standing stock are environmentally important. In fact, Post et al. (1995) conclude that a change of global or regional soil $\mathrm{C}$ inventory on the order of $1 \mathrm{Pg} \mathrm{C}$ would be impossible to measure directly. Even a $1 \mathrm{Pg} \mathrm{C} \mathrm{y}^{-1}$ sink continuously for $30 \mathrm{y}$ would increase the global soil $\mathrm{C}$ inventory by only two percent. While changes in C stocks associated with land use change are frequently observed, a recent study documented a regional change in carbon stock in unmanaged and managed soils. Bellamy et al. (2005) found that the top $15 \mathrm{~cm}$ of soils in Great Britain have lost two percent of their $\mathrm{C}$ stocks over the past $25 \mathrm{y}$. Because the soil $\mathrm{C}$ loss was fairly independent of land use, they conclude that the observed warming in Great Britain is the most likely explanation for the loss.

\subsection{CLIMATE CHANGE}


One of the most important questions regarding SOM is how future climate change will influence decomposition rates, and the flux of $\mathrm{CO}_{2}$ from soils to the atmosphere, relative to $\mathrm{CO}_{2}$ uptake by NPP_ and thus the potential for positive feedback with climate change. For example, across a gradient of mean annual temperature in intact mature tropical forests, NPP increased, but soil C stocks decreased more steeply, implying a net loss in ecosystem C from faster SOM decomposition (Raich et al. 2006). To some extent, these linkages can be evaluated by land surface models coupled to global climate models. In a recent inter-comparison of coupled climate carbon-cycle models (the Coupled Carbon Cycle Climate Model Intercomparison Project, or $\left.\mathrm{C}^{4} \mathrm{MIP}\right)$, all but one of eleven models predicted faster decomposition rates with climate change to 2100 (Friedlingstein 2006). Because modeled NPP did not increase commensurately, most of these simulations predicted decreases or no change in soil carbon stocks and a positive feedback with climate change. Current observations show that terrestrial ecosystems, vegetation and presumably soil as well, currently act as a large sink for atmospheric $\mathrm{CO}_{2}$. However, all of the models in the previous study predicted that terrestrial ecosystems will be a less effective sink, and in many simulations become a net $\mathrm{C}$ source, after 2070 (Fischlin et al. 2007; Friedlingstein et al. 2006).

The coupling between $\mathrm{C}$ and $\mathrm{N}$ cycling in soil, in which decomposition also mineralizes nitrogen, means that the net effect of increased decomposition on ecosystem carbon budgets is complex. The direct effect of increased decomposition is the transfer of $\mathrm{C}$ from soils to atmospheric $\mathrm{CO}_{2}$. On the other hand, stimulation of decomposition in relatively undisturbed ecosystems may cause ecosystems to accumulate $\mathrm{C}$ as nutrients are transferred from soils (low $\mathrm{C} / \mathrm{N}$ ratio) to plant reservoirs with higher $\mathrm{C} / \mathrm{N}$ ratios. Few land surface models simulate these nitrogen transformations in soil and plants, and thus most are likely missing an important 
modulator of $\mathrm{CO}_{2}$ and climate impacts. For example, none of the eleven soil modules in the $\mathrm{C}^{4} \mathrm{MIP}$ takes into account the release of nitrogen through increased decomposition and its potential to stimulate plant growth. Including this nitrogen feedback in the CENTURY biogeochemical model reduced the loss of soil organic $\mathrm{C}$ due to increasing temperature by half compared to simulations without the nitrogen processes (Schimel et al. 1994). Nitrogen cycling in the land surface model CN, coupled to the Community Climate Simulation Model (but not in $\mathrm{C}^{4} \mathrm{MIP}$ ) had a similar effect in maintaining ecosystem $\mathrm{C}$ stocks (Thornton and Rosenbloom 2005). Predicting the ability of coupled $\mathrm{C}$ and $\mathrm{N}$ cycles to buffer the impacts of climate change requires better understanding and integration of soil decomposition, nutrient cycling, and plant growth.

The magnitude, rate, and duration of ecosystem soil responses to climate change depend on the amount of soil $\mathrm{C}$ and the rates at which it cycles. Soils in dry tropical forests tend to have less $\mathrm{C}$ per unit area and slower rates of $\mathrm{C}$ turnover times than do wetter tropical forests (Raich and Schlesinger 1992). Modeling and radiocarbon studies show that soil $\mathrm{CO}_{2}$ fluxes per unit area from tropical forest soils are an order of magnitude greater than those from temperate or boreal forest soils (Trumbore 2000). These large, fast-cycling C stocks are therefore predicted to dominate short-term, interannual, response to climate variations (Townsend et al. 1995; Trumbore et al. 1996). In contrast, the large stocks of soil organic matter in high latitude tundra, forests, and peatlands cycle very slowly because decomposition is restricted by low temperatures and anoxia from saturation (Carrasco et al. 2006). If these soils are warmed, decomposition and emissions of $\mathrm{CO}_{2}$ and $\mathrm{CH}_{4}$ will proceed rapidly, leading to a large positive feedback with climate change. Indeed, year-to-year differences in decomposition of old SOM in some boreal forest soils can determine the status of entire forest stands as net sources or sinks of C (Goulden et al. 
1998). Because gross $C$ fluxes at high latitudes are small compared to those in the tropics, it is unlikely that even large interannual variability in those fluxes could be as important in affecting the short term (annual) $\mathrm{C}$ balance of the atmosphere. However, the potential for a large, longterm (decadal to century) response of soil $\mathrm{C}$ to climate change is greatest at higher latitudes, because much more organic $\mathrm{C}$ is stored there.

In addition to the large $\mathrm{C}$ stocks in high-latitude soils, the $900 \mathrm{Pg} \mathrm{C}$ in permafrost, about half of which is contained in deep, relict, loess soils from the last glacial period, may also be vulnerable to warming. The radiocarbon content of $\mathrm{CO}_{2}$ and $\mathrm{CH}_{4}$ in soil pore spaces, bubbles, and diffusive gas flux in these areas indicates that in many sites this $\mathrm{C}$ was fixed 10-20 thousand years ago, and as the permafrost thaws $\mathrm{C}$ in the ancient soil is being released to the atmosphere (Zimov et al. 2006).

Earth has warmed significantly over the past 150 years. The land areas of earth have warmed $0.27^{\circ} \mathrm{C}$ per decade since 1979 and almost $1^{\circ} \mathrm{C}$ since 1850 (IPCC 2007). Considering only the effect of temperature on decomposition, soils should be an increasing source of atmospheric $\mathrm{CO}_{2}$. However, trends in soil moisture, plant growth, and recovery of $\mathrm{C}$ stocks in previously eroded agricultural regions influence $\mathrm{C}$ flows in ways that may reverse this pattern in some places. In some regions, the interacting effects of temperature and moisture on plant growth and decomposition, as well as changes in plant litter quality (from changes in species composition and plant partitioning) and the nitrogen interaction described above may be as important as the direct effects of warming on soil processes. Accurate assessment and prediction require considering microbial, plant, and microclimate influences on carbon flows.

Land surface models do not currently include landscape factors, like soil history and erosion, that can affect whether soils acts as regional net sources or sinks. For example, the retreat of the 
Laurentide ice sheet at the termination of the last ice age led to a period of terrestrial $\mathrm{C}$ accumulation as soils developed (Harden et al. 1992). Erosion and burial of soil in the $19^{\text {th }}$ and early $20^{\text {th }}$ centuries, combined with regrowth of vegetation on eroded soil, likely have led to overall C sinks in soils in the US and western Europe in the last decades (Van Oost et al. 2007). Ignoring such processes may lead to large errors in analyses of land use change or in coupled carbon-climate models.

\subsection{LAND USE AND LAND COVER CHANGE}

\subsubsection{Disturbance}

Disturbances that affect soil C cycling include fires and floods, deforestation, cultivation, and drainage or fields, bogs, forests, and wetlands. All of these alter C inputs and losses to soil by changing vegetation, soil structure, temperature, water balance, and nutrient availability. Rates of change in organic $\mathrm{C}$ stocks in response to disturbance can be an order of magnitude larger than those associated with response to increased productivity or climate variability, because the changes in ecosystem inputs and decomposition rates are more extreme for disturbance.

Wildfires are predicted to get more frequent and severe in many regions due to climate change, particularly in regions that do not practice active fires suppression (Fried et al. 2008). Fire influences ecosystem $\mathrm{C}$ cycling by removing biomass and litter, and creating black (pyrolyzed) carbon. In boreal forests and Mediterranean chaparral, decomposition is slow enough that it is less important than periodic removal of biomass by fire for returning $\mathrm{CO}_{2}$ to the atmosphere. In boreal forests, warmer temperatures and more summer drought may be increasing the frequency and severity of fires, which, in turn, eliminate the moss layer that helps insulate the permafrost. Both factors, the loss of permafrost and more severe burning, are predicted to drive 
these ecosystems to become net $\mathrm{C}$ sources (Harden et al. 2000). As mentioned in the section on recalcitrance, grasslands in Australia with frequent fires have relatively high proportions of chemically recalcitrant black carbon (Krull et al. 2006). Changes in fire frequency linked to climate or land management may ultimately control a region's status as a C source or sink.

\subsubsection{Land Management}

During the past two centuries, agricultural expansion has led to large losses of soil C. Soils may lose a significant portion of their $\mathrm{C}$ when native ecosystems are replaced by less productive ones; these changes represent a loss of fast-cycling $\mathrm{C}$ rather than passive $\mathrm{C}$ pools (Davidson and Ackerman 1993; Harrison et al. 1993; Trumbore et al. 1995; Stallard 1998). Tillage leads to substantial losses of old soil $\mathrm{C}$ due physical disruption of soil aggregates and enhanced aeration of the soil that exposes organic matter to microbes and oxidization (e.g., Tisdall and Oades 1982; Tiessen and Stewart 1983b; Baisden et al. 2002; Ewing et al. 2006). Based on a careful assessment of soil $\mathrm{C}$ stocks in pairs of uncultivated and cultivated fields, cultivation reduces $\mathrm{C}$ stocks by $25-30 \%$ within five years in temperate regions and faster (within two years) in the tropics (Davidson and Ackerman, 1993). The fraction of C lost is even higher in the A horizon.

Agricultural management that does not rely on tillage, such a bare-fallow and stubble-mulch practices, can greatly reduce carbon losses (Cambardella and Elliott 1992). Moreover, converting tilled land to no-till agriculture can lead to rapid increases in soil C stocks, at least near the soil surface (Lal and Bruce 1999). Consequently, management of cropping systems may have potential for $\mathrm{C}$ sequestration and has been promoted as a way to offset anthropogenic $\mathrm{C}$ emissions (Kong et al. 2005). Soil C is a resource that is potentially manageable, particularly in agricultural and pasture lands, although it is important to understand that soils have a finite 
capacity for $\mathrm{C}$ sequestration (Six et al. 2002). Predicting these limits requires understanding the mechanisms controlling SOM stabilization.

Globally, land conversion rates are highest in the tropics and a significant proportion of this zone is in some state of recovery from past disturbance, mainly as forests succeed former pastures and croplands. Where productivity is high, soils under regrowing forests have been identified as another potential $\mathrm{C}$ sink, with sequestration capacity contingent on site history and climate. It may be more favorable in wet forests where soil decomposition rates are lower than in dry or moist sites (Silver et al. 2000; Guo and Gifford 2002), and in sites that have not been highly degraded, for example by intensive use of pasture and subsequent compaction, and where pre-existing forest root systems were not heavily damaged.

\subsection{TEMPORAL DIMENSIONS OF SOILS AS SOURCES OR SINKS OF CARBON}

As soils and ecosystems develop, they gain and lose C. For example, approximately $25 \%$ of the world's SOM is stored in soils that began developing after the last major deglaciation (Harden et al. 1992). Based on chronosequence studies, these soils are still functioning as longterm sinks for atmospheric $\mathrm{CO}_{2}$. Similarly, we predict that older soils may be acting as long-term net sources of $\mathrm{CO}_{2}$ to the atmosphere because of declines in NPP and weathering of minerals to more stable forms. Export of $\mathrm{C}$ from upland soils in dissolved or particulate form ultimately leads to transport into the oceans. While it is unclear whether, globally, soils were at steady state pre-1850, net $\mathrm{C}$ fluxes from soils to the atmosphere have been accelerated by large-scale landcover changes over the past 150 years.

As described above, on decadal to century time scales, the net $\mathrm{C}$ balance of soils may be dominated by disturbance regime and frequency. Disturbance-dominated ecosystems are characterized by short periods of rapid C loss (e.g., from fires, large storms and blow-downs, 
insect mortality, or floods), followed by longer periods of $\mathrm{C}$ accumulation as they recover. Net $\mathrm{C}$ accumulation between disturbances may be rapid compared to the long-term rates associated with soil development and the associated alteration of soil minerals. However, when averaged over long times or large spatial scales (which include many stages of disturbance and recovery), the long-term rates should dominate.

Superimposed on the oscillations of disturbance and recovery is interannual variability in $\mathrm{C}$ flux from soils driven by variability in productivity and decay. Decay rates are of course directly and rapidly affected by climate anomalies such as droughts and heat waves. Soil respiration also responds to changes in plant inputs, though. In addition to the magnitude of variability in these component processes, the net variability will also be determined by the lag time between $\mathrm{C}$ uptake by photosynthesis and respiration, which is a function of ecosystem $\mathrm{C}$ turnover times (Trumbore 2000). For example, if most organic C is respired within a year of fixation, enhanced plant productivity in a given year will be offset by increased decomposition in the same year. However, if lag times are longer, higher than average productivity in one year would lead to net $\mathrm{C}$ gain, with net $\mathrm{C}$ loss in following years, as the pulse of high productivity is decomposed slowly over time.

\section{CONCLUSIONS AND FUTURE PROSPECTS}

As the focus on soil organic matter has grown to encompass its pivotal role in the global carbon cycle and climate, the study of organic matter in soil has taken on new importance. Climatic change will cause ecosystems to experience novel and rapidly changing conditions, as well as putting new demands on land management for carbon sequestration. Accurately predicting future atmospheric $\mathrm{CO}_{2}$ concentrations and better managing soil resources will require a clear understanding of the processes and mechanisms controlling SOM storage and turnover. 
There is a need for models that can predict ecosystem response to novel or long term forcing. The numerical models used to simulate soil $\mathrm{C}$ cycling largely all share the same rules governing allocation of plant inputs, structure (C pools), and controls of turnover time. They incorporate multiple soil carbon pools, detailed plant growth modules, and temperature response functions (e.g., the CENTURY family, RothC, CASA, IBIS, Orchidee, LPJ, CN). Yet there is much room for improvement, in at least three important ways. First, while temperature and moisture interact to control decomposition and are predicted to change in novel combinations in the future, most models treat their effects as independent. Second, models rely on clay content as a proxy for the host of physical stabilization mechanisms in soil, if they include them at all. Finally, plant tissue chemistry drives model partitioning of inputs into pools of different turnover time, yet intrinsic plant compound recalcitrance is much less important than previously thought. These model simplifications exist in large part because the growing understanding of the processes that influence turnover time has occurred rapidly, and has yet to be translated into mathematical functions that operate on an area basis (i.e., per $\mathrm{m}^{2}$ ) and depend on variables that are regionally or globally available.

We have in hand sufficient understanding and data to begin development of much-improved model parameterizations, including the influence of plant allocation, soil mineralogy, and climate conditions. However, fundamental research targeting these areas, in parallel with model development, is still needed. There are many fruitful areas for future research; we suggest that priority be given to those processes and ecosystems that are vulnerable to global change, are potentially manageable, represent a large stock of carbon, and could influence atmospheric $\mathrm{CO}_{2}$ concentrations significantly within the next several decades. 
In the last decade, exciting new molecular, genomic, and imaging techniques have emerged for probing soil organic matter at atomic and molecular scales, such as soft-energy x-ray (for example the Advanced Light Source); Secondary ion mass spectrometry (SIMS, nano-SIMS), and Pyrolysis-gas chromatography-mass spectrometry-isotope ratio mass spectrometry (Py-GCMS-IRMS), and gene-based microarrays. These techniques can be used in combination with isotopic analysis $\left({ }^{13} \mathrm{C},{ }^{14} \mathrm{C}\right)$ to explore detailed characterizations to turnover times. The vanguard, then, is utilizing these techniques in the context of experiments and controlled environmental gradients to gain insight at the landscape scale.

In terms of improving our ability to predict soil $\mathrm{C}$ turnover, we identify five priorities for research: (1) The interactive effects of temperature and moisture on microbial decomposition rates, because soils will experience novel and transient conditions. (2) The mechanisms governing protection of OM through interactions with mineral surfaces and due to spatial structure. (3) The mechanisms leading to slower OM turnover times with depth. (4) The potential for and importance of non-linear responses of decomposition to $\mathrm{C}$ availability; for examples, the role of labile $\mathrm{C}$ inputs in stimulating decomposition of less labile OM (i.e., priming) and densitydependent microbial behavior. (5) Finally, how the chemical characteristics of organic compounds, as inputs from different plant species, charred (black) carbon, or microbial cell walls and byproducts, influence mechanisms of stabilization and turnover. 


\section{APPENDIX 1. METHODS OF RADIOCARBON $\left({ }^{14} \mathrm{C}\right)$ ANALYSIS AND REPORTING OF ${ }^{14}$ C DATA}

\subsection{BACKGROUND INFORMATION}

In this Appendix we briefly describe sample preparation and radiocarbon analysis, as well as the conventions for reporting of ${ }^{14} \mathrm{C}$ data. We have tried to strike a balance between brevity and explanation, addressing common questions we have encountered. Additionally, we urge those

interested in using ${ }^{14} \mathrm{C}$ data to read Stuiver and Polach (1977), the paper that established most ${ }^{14} \mathrm{C}$ reporting conventions and from which most of the equations in this appendix were acquired.

\subsection{RADIOCARBON SAMPLE PREPARATION}

There are two methods for measuring radiocarbon: decay counting and accelerator mass spectrometry (AMS). Decay counting measures the electrons emitted during radioactive decay of ${ }^{14} \mathrm{C}$ to ${ }^{14} \mathrm{~N}$, measuring electrical pulses (gas counting) or light pulses (scintillation counting). Samples with a natural abundance of ${ }^{14} \mathrm{C}$ have relatively few decays per gram, because the halflife of ${ }^{14} \mathrm{C}$ is 5,730 years. As a result, several grams of carbon and days or weeks of counting are required to observe enough decay events for a precise estimate of the ${ }^{14} \mathrm{C}$ concentration.

AMS directly measures the number of ${ }^{14} \mathrm{C}$ atoms, and the ratio of ${ }^{14} \mathrm{C}$ to ${ }^{13} \mathrm{C}$ and $/$ or ${ }^{12} \mathrm{C}$, using a high-energy accelerator as an inlet to a mass spectrometer. The key characteristics of ${ }^{14} \mathrm{C}$ AMS are the electron stripping and ion acceleration, which allow ${ }^{14} \mathrm{C}$ to be distinguished from isobars and molecules that would confuse a standard mass spectrometer. AMS requires only a fairly small sample of $100 \mu \mathrm{g}$ to $1 \mathrm{mg}$ of $\mathrm{C}$. In addition, the measurement only takes minutes per sample.

To measure ${ }^{14} \mathrm{C}$ in plant tissue or soils with AMS, the organic $\mathrm{C}$ must first be completely combusted to $\mathrm{CO}_{2}$. Enough homogenized sample to provide $\sim 1 \mathrm{mg} \mathrm{C}$ is added to a quartz glass 
tube with $\mathrm{CuO}$ and $\mathrm{Ag}$. The tube is then evacuated, sealed, and combusted at $\sim 900^{\circ} \mathrm{C}$ (Buchanan and Corcoran 1959). After combustion, or for gas samples from air or soil gas, the $\mathrm{CO}_{2}$ in the sample is purified cryogenically and then reduced to graphite on an iron or cobalt catalyst using zinc (Xu et al. 2007) or hydrogen (Vogel et al., 1984). The graphite is pounded or pressed into a small sample holder called a target. In the AMS, the target is bombarded by a Cs beam to deliver a stream of $\mathrm{C}$ ions. Samples for decay counting are combusted at similar temperatures in a large vacuum line (Goh 1991). The resulting $\mathrm{CO}_{2}$ is cryogenically purified, then counted directly (gas counting) or converted to acetylene or benzene (scintillation counting). For more details on experimental methods, see Goh (1991) and Trumbore (1996).

For both decay counting and AMS, it is critical to prepare standard materials of known ${ }^{14} \mathrm{C} /{ }^{12} \mathrm{C}$ content. These include the $\mathrm{OX} 1$ standard described below and materials relatable to it, as well as materials that are radiocarbon-free). Standards allow assessment of the overall accuracy and the effects of sample pretreatment procedures, and radiocarbon-free samples provide a blank to determine the radiocarbon introduced to the sample during processing.

\subsection{REPORTING OF RADIOCARBON DATA}

Both AMS and conventional counting facilities report ${ }^{14} \mathrm{C}$ data as the ratio of ${ }^{14} \mathrm{C}$ activity in the sample to that of a known standard. By convention (Broecker and Olson, 1959; Stuiver and Polach, 1977), the standard is corrected to 0.95 times the activity of an oxalic acid standard (OX1), which is normalized to a $\delta^{13} \mathrm{C}$ of $-19 \%$. The sample is also normalized for ${ }^{13} \mathrm{C}$ content as

follows. The activity of the sample, $A_{S}$, with a $\delta^{13} \mathrm{C}$ of $\delta$ is corrected to a constant ${ }^{13} \mathrm{C}$ abundance $(-25 \%$ o), using the following equation:

$$
\mathrm{A}_{\mathrm{SN}}=\mathrm{A}_{\mathrm{S}} \frac{(1-25 / 1000)^{2}}{(1+\delta / 1000)^{2}}
$$


where $A_{S N}={ }^{13} \mathrm{C}$-corrected sample activity and $A_{S}=\mathrm{un}-{ }^{13} \mathrm{C}$-corrected activity of the sample. These ${ }^{13} \mathrm{C}$ corrections account for mass-dependent isotopic fractionation effects (Stuiver and Polach, 1977), and are a crucial part of the analysis. For example, the $\delta^{13} \mathrm{C}$ difference between atmospheric $\mathrm{CO}_{2}$ and carbon fixed during photosynthesis by $\mathrm{C}_{3}$ plants is approximately $20 \%$. Assuming that the fractionation of ${ }^{14} \mathrm{C}$ is roughly twice that of ${ }^{13} \mathrm{C}$ (since the mass difference between 12 and 14 is twice that between 12 and 13; i.e., mass dependent fractionation), the difference in ${ }^{14} \mathrm{C}$ abundance, if one didn't do the correction in equation $\mathrm{A} 1.1$, between atmospheric $\mathrm{CO}_{2}$ and photosynthate will be approximately $40 \%$ (equivalent to $330{ }^{14} \mathrm{C}$ years), even though both $\mathrm{CO}_{2}$ and photosynthates are the same "age." Reporting radiocarbon data corrected to a common $\delta^{13} \mathrm{C}$ value eliminates isotope fractionation effects and allows differences in age to be ascertained directly. It also allows analysis of SOM ${ }^{14} \mathrm{C}$ without having to quantify plant or microbial fractionation.

The standard approach to correcting for ${ }^{13} \mathrm{C}$ that is described above is applicable when fractionation is due to mass-dependent processes. This covers most diffusive and biological processes. One case where fractionation is not mass dependent is the alteration of $\delta^{13} \mathrm{C}$ values by physically mixing $\mathrm{CO}_{2}$ sources, as is done in elevated $\mathrm{CO}_{2}$ experiments. For that reason, a different equation should be used for the ${ }^{13} \mathrm{C}$ correction for samples from managed- $\mathrm{CO}_{2}$ environments or experiments using purposeful C isotope tracer manipulations (Torn and Southon 2002).

A common term used for reporting ${ }^{14} \mathrm{C}$ data is "fraction Modern" or $\mathrm{F}^{14} \mathrm{C}$ (Reimer et al., 2004): 


$$
F^{14} C=\frac{\mathrm{A}_{\mathrm{SN}}}{\mathrm{A}_{\mathrm{ON}}}=\frac{\left(\frac{{ }^{14} C}{{ }^{12} C+{ }^{13} C}\right)_{\text {sample }(-25)}}{0.95\left(\frac{{ }^{14} C}{{ }^{12} C+{ }^{13} C}\right)_{\mathrm{OX}(-19)}}
$$

where $A_{S N}$ is as defined above for Eq. A1.1 and $A_{O N}$ is 0.95 times the measured activity of the OX1 standard normalized to a $\delta^{13} \mathrm{C}$ of $-19 \%$.

The conventional radiocarbon age, reported by AMS labs and used in archaeology, is:

$$
{ }^{14} \mathrm{C} \text { age }=-8,033 \ln F^{14} C,
$$

where $8,033 \mathrm{y}$ is the Libby mean life of radiocarbon. Note that the true mean life of radiocarbon is $8267 \mathrm{y}$ (the Libby mean life is used for this unit by convention), so the ${ }^{14} \mathrm{C}$ age is not an accurate calculation of true age of the sample. Radiocarbon ages are referenced to 1950 such that 1950 A.D. $=0$ B.P. Samples with more ${ }^{14} \mathrm{C}$ than the 1950 atmosphere (i.e. those with $\mathrm{F}^{14} \mathrm{C}>1$ ) are commonly reported as "> Modern".

Great care must be taken in using the conventional radiocarbon age, which is almost never used directly. In some cases the actual age of an object in soil is required - for example, for determining the age of a seed or a piece of undecomposed sphagnum in a peat bog. Such an age can only be calculated for something that formed in a single year (or short time span) and presumed not to have exchanged carbon with its surroundings after being added to the soil. In such cases, the Libby age must be converted to a calendar age using appropriate calibration curves—several programs for this are available through the journal Radiocarbon web site, www.radiocarbon.org. The age with the Libby half-life is almost never used except as the basis for calculating calibrated ages, and should not be used to estimate mean residence times of carbon in soil directly. 
The activity of OX1 changes through time as ${ }^{14} \mathrm{C}$ in the standard decays (i.e., A $\mathrm{ON}$ measured in 2007 is less than if it were measured in 1950). For dating purposes, both the sample and $\mathrm{A}_{\mathrm{ON}}$ decrease at the same rate (the radiocarbon decay constant). In other words, $\mathrm{F}^{14} \mathrm{C}$ is constant with time. However, when considering an open and dynamic system, such as soil, the need arises for a standard that represents a constant value. Stuiver and Polach (1977) thus proposed an absolute international standard activity $\left(\mathrm{A}_{\mathrm{abs}}\right)$ that would incorporate a yearly correction for the decay in the OX1 standard:

$$
\mathrm{A}_{\mathrm{abs}}=\mathrm{A}_{\mathrm{oN}} \exp ^{\lambda(y-1950)}
$$

and $y$ is the year of sample collection and $\lambda=1 / 8267 \mathrm{y}^{-1}=1.210 \times 10^{-4} \mathrm{y}^{-1}$. (This $\lambda$ is the true radiodecay constant rather than that derived from the Libby mean life of 8033 years.) The ratio $\mathrm{A}_{\mathrm{SN}} / \mathrm{A}_{\mathrm{abs}}$ therefore differs from $\mathrm{F}^{14} \mathrm{C}$ by the factor $\exp (-\lambda(\mathrm{y}-1950))$, and will decrease with time since the ${ }^{14} \mathrm{C}$ in the sample radiodecays but the amount in the standard stays the same as in 1950 .

The most commonly reported ${ }^{14} \mathrm{C}$ unit in biogeochemical studies is $\Delta^{14} \mathrm{C}$. This parameter is the deviation in parts per thousand (per mil, \%o) from the absolute standard $\left(\mathrm{A}_{\mathrm{abs}}\right)$ :

$$
\Delta^{14} C=\left[\frac{A_{S N}}{A_{a b s}}-1\right] x 1000=\left[F^{14} C \times \exp \left(\frac{\left(\frac{-(y-1950)}{8267}\right)}{2}-1\right] \times 1000 .\right.
$$

Positive values of $\Delta^{14} \mathrm{C}$ indicate the presence of bomb-produced ${ }^{14} \mathrm{C}$. Conversely, negative values of $\Delta^{14} \mathrm{C}$ indicate the predominance of $\mathrm{C}$ fixed from the atmosphere long enough ago for significant radioactive decay of ${ }^{14} \mathrm{C}$ to have occurred.

Most radiocarbon measurement facilities provide the analysis results in different formats, depending on the needs of the researchers. Forms in which results are commonly reported include $\mathrm{F}^{14} \mathrm{C}, \Delta{ }^{14} \mathrm{C}$, and ${ }^{14} \mathrm{C}$ age. Conversion between the various units can be done using equations $\mathrm{A} 1.6$ and $\mathrm{A} 1.7$. If only $\Delta^{\mathbf{1 4}} \mathrm{C}$ data are reported or published, it is important to state 
the year of measurement, since values of $\Delta^{14} \mathrm{C}$ will be specific to that year. The analytical precision typically reported with the data is the 1 sigma error, determined from counting statistics and propagating laboratory errors. Typical precision reported for samples with $\mathrm{F}^{14} \mathrm{C} \sim 1$ is $+/-0.005$ (or $\pm 5 \%$ ofor $\Delta^{14} \mathrm{C}$ ), and as low as $0.001( \pm 1 \%$ ) for high-precision analyses. Accuracy is usually reported based on the repeated analysis of secondary standards of known $\mathrm{F}^{14} \mathrm{C}$, or at least materials for which a consensus value exists, and is laboratory-specific.

\section{APPENDIX 2. MODELING CARBON DYNAMICS USING RADIOCARBON MEASUREMENTS}

\subsection{BACKGROUND INFORMATION}

Soil organic matter (SOM) is a heterogeneous reservoir with a variety of turnover times, to which carbon is continuously added (as new plant matter) and lost (as $\mathrm{CO}_{2}$, leached organic matter, or eroded material). These dynamics preclude using radiocarbon to meaningfully "date" SOM, and at best the ${ }^{14} \mathrm{C}$-based age of SOM represents the average ${ }^{14} \mathrm{C}$ age of a carbon atom in the soil reservoir. This tells us relatively little about the distribution of $\mathrm{C}$ in reservoirs with different turnover times, and can be quite misleading when the SOM has incorporated 'bomb ${ }^{14} \mathrm{C}^{\prime}$ created through atmospheric nuclear weapons testing. In this Appendix we describe methods of using ${ }^{14} \mathrm{C}$ to estimate turnover times of soil organic $\mathrm{C}$. These methods differ somewhat when the source is natural radiocarbon ('pre-bomb') or bomb ${ }^{14} \mathrm{C}$, and when the system is assumed to be at steady-state or changing.

\subsection{STEADY-STATE SYSTEMS}

\subsubsection{Natural Radiocarbon - for samples collected prior to 1950 , or assumed to contain no bomb radiocarbon}

For samples not complicated by the presence of bomb ${ }^{14} \mathrm{C}$, the ratio of ${ }^{14} \mathrm{C} /{ }^{12} \mathrm{C}$ measured in a sample represents the rate of decomposition relative to the rate of radiodecay of ${ }^{14} \mathrm{C}$. This 
treatment is most useful for very old $\mathrm{C}$ found in soils. For a homogeneous carbon-containing reservoir, $i$, with input rate $I_{i}$, first-order decomposition constant $k_{i}$, and carbon content $C_{i}$, the change in stock over time (balance of inputs and outputs) is:

$$
d C_{i} / d t=I_{i}-k_{i} C_{i}
$$

For a steady-state reservoir, $\mathrm{k}_{\mathrm{i}}=\mathrm{I}_{\mathrm{i}} / \mathrm{C}_{\mathrm{i}}$. Since turnover time $(\tau)$ is defined as $1 / \mathrm{k}_{\mathrm{i}}$, at steady state, $\tau$ equals the inventory of carbon divided by the input rate, $C_{i} / I_{i}$.

The balance of ${ }^{14} \mathrm{C}$ atoms in the same reservoir $\left({ }^{14} \mathrm{C}_{\mathrm{i}}=\mathrm{F}_{\mathrm{i}} \mathrm{C}_{\mathrm{i}}\right)$ will reflect the rate of loss from decomposition, $\mathrm{k}_{\mathrm{i}}$, as well as the rate constant for radioactive decay of ${ }^{14} \mathrm{C}, \lambda(\lambda=1.210 \times$ $10^{-4} \mathrm{y}^{-1}$ ), and the rate of inputs (in this case, from the atmosphere):

$$
\mathrm{dF}_{i} / \mathrm{d} t=\left(1 / C_{i}\right)\left(I_{i} F_{\text {atmosphere }}-\left(k_{i}+\lambda\right) F_{i} C_{i}\right)
$$

At steady state and assuming that $\mathrm{F}_{\text {atmosphere }}$ before $1959=1$,

$$
F_{i}=\left(1 / C_{i}\right)\left(I_{i} /\left(k_{i}+\lambda\right)\right)
$$

Since at steady state, $\mathrm{C}_{\mathrm{i}}=\mathrm{I}_{\mathrm{i}} / \mathrm{k}_{\mathrm{i}}$, Equation $(\mathrm{A} 2.3)$ may be rewritten as:

$$
F_{i}=\left(k_{i} /\left(k_{i}+\lambda\right)\right)
$$

For components with short turnover times $\left(\mathrm{k}_{\mathrm{i}}>\lambda\right)$, a calculated ${ }^{14} \mathrm{C}$ age will approximate the turnover time, $\tau\left(1 / \mathrm{k}_{\mathrm{i}}\right)$. For components with $\mathrm{k}_{\mathrm{i}}$ equal to or less than the decay constant for radiocarbon, the age will be less than the turnover time. For example, the ${ }^{14} \mathrm{C}$ age calculated for a steady-state reservoir with $\mathrm{k}_{\mathrm{i}}=0.01 \mathrm{y}^{-1}(\tau=100 \mathrm{y})$ would be $100 \mathrm{y}$, while that for a component with $\mathrm{k}_{\mathrm{i}}=0.0002 \mathrm{y}^{-1}(\tau=5000 \mathrm{y})$ would be $3,910 \mathrm{y}$. 
Note that this approach assumes $\mathrm{F}^{14} \mathrm{C}=1.0$ and is constant prior to 1950 . Actually the ${ }^{14} \mathrm{C} /{ }^{12} \mathrm{C}$ of atmospheric $\mathrm{CO}_{2}$ did vary with time prior to 1900 , mostly reflecting changes in the rate of ${ }^{14} \mathrm{C}$ production in the upper atmosphere. During the Holocene, these variations were less than $10 \%$, and they are documented in the calibration data sets based on ${ }^{14} \mathrm{C}$ measured in knownage wood. Between 1900 and 1950, $\mathrm{F}_{\text {atm }}$ declined due to the addition of ${ }^{14} \mathrm{C}$-free $\mathrm{CO}_{2}$ derived from fossil fuels, known as the Suess effect. Modeling of turnover times should use the actual atmospheric ${ }^{14} \mathrm{C}$ inputs to photosynthesis, although it is not as important before 1959 as after.

\subsubsection{Bomb Radiocarbon}

One of the great uses of radiocarbon for soil organic matter studies is the ability to estimate the turnover time of organic carbon based on the degree to which it has incorporated bomb radiocarbon in the last 50 years. This provides one of the only tools to study $\mathrm{C}$ dynamics on decadal timescales.

For a steady state system, a time-dependent model is used because of the irregular shape of the atmospheric ${ }^{14} \mathrm{CO}_{2}$ record. This model accounts for radioactive decay of the ${ }^{14} \mathrm{C}$ since 1950 explicitly, and requires that we compare measured radiocarbon to a standard with a radiocarbon value that stays constant over time $\left(\mathrm{A}_{\mathrm{abs}}\right)$. For ease, we define $\mathrm{F}^{\prime}$ here as $\mathrm{A}_{\mathrm{SN}} / \mathrm{A}_{\mathrm{abs}}$ (see equation A1.4) for samples measured since 1950 ; F' equals $\Delta^{14} \mathrm{C} / 1000+1$. For a reservoir at steady state, the balance of radiocarbon entering and leaving the reservoir in year $t$ is given by:

$$
F_{C, t}^{\prime}=\frac{\left[I F_{a t m, t}^{\prime}+C_{t-1} F_{C, t-1}^{\prime}(1-k-\lambda)\right]}{C_{t}}
$$

Since the reservoir is at steady state, $\mathrm{C}_{(\mathrm{t}-1)}=\mathrm{C}_{(\mathrm{t})}=\mathrm{I} / \mathrm{k}$, so Equation (A2.5) reduces to:

$$
F_{C, t}^{\prime}=k F_{a t m, t}^{\prime}+F_{C, t-1}^{\prime}(1-k-\lambda)
$$


Figure 8 shows the predicted values of ${ }^{14} \mathrm{C}$ in 1996 for a homogeneous, steady state reservoir with different turnover times. For turnover times $<50 \mathrm{y}$, it is clear that two different turnover times may yield the same $\Delta^{14} \mathrm{C}$ value. To distinguish which of these two turnover times is correct, we use one of two methods. First, if an archived sample from the same soil is available, radiocarbon measurements may distinguish between the two possibilities. Organic matter with shorter turnover times will have decreased ${ }^{14} \mathrm{C}$ over the past several decades, while those with longer turnover times will have increased in ${ }^{14} \mathrm{C}$. If no archived soil is available, knowledge of the $\mathrm{C}$ stock and $\mathrm{C}$ fluxes into and out of the soil may be used to determine the correct turnover time (since $\tau=$ stock/flux), as illustrated here.

The $\Delta^{14} \mathrm{C}$ values measured in low-density organic matter isolated from the A horizon of a soil sampled in 1956 and 1992 in the Sierra Nevada were $-31 \%$ and $+127 \%$, respectively (Trumbore et al., 1995). This ${ }^{14} \mathrm{C}$ increase is consistent with either a turnover time of 5 or $57 \mathrm{y}$. The total amount of low-density carbon in the A horizon was $6.5 \mathrm{~kg} \mathrm{C} \mathrm{m}^{-2}$, with low-density carbon accounting for nearly $90 \%$ of the carbon in this layer. The 5-year turnover time implies annual $\mathrm{C}$ inputs from litter of $\sim 1,300 \mathrm{~g} \mathrm{C} \mathrm{m}^{-2} \mathrm{yr}^{-1}$, while the 57 -year turnover time implies inputs of only $114 \mathrm{~g} \mathrm{C} \mathrm{m}^{-2} \mathrm{yr}^{-1}$. The measured aboveground litterfall at a nearby site was $\sim 100 \mathrm{~g} \mathrm{C} \mathrm{m}^{-2}$ $\mathrm{yr}^{-1}$. Hence, the most reasonable turnover time is $57 \mathrm{y}$ for the low-density organic matter in the A horizon.

A potential problem with this approach is the uncertainty as to whether the reservoir under consideration is homogeneous. Bulk SOM is almost certainly heterogeneous, and the bulk ${ }^{14} \mathrm{C}$ value does not give a good idea of SOM dynamics. Even low-density organic matter is made up of relatively fresh litter material (small roots and pieces of leaves) as well as more humified materials that likely have slower turnover. Normally, the soil must be split into components with 
different turnover times using fractionation methods outlined in the text. For each component, a new measurement constraint (such as total $\mathrm{C}$ flux into and out of the soil) must be added to arrive at a unique solution. A second problem is that carbon entering the soil as litter may not have the ${ }^{14} \mathrm{C}$ signature of that year's atmospheric $\mathrm{CO}_{2}\left(\mathrm{~F}^{\prime}\right.$ atm in the equations above $)$. For example, conifer needles often reside on trees for several years before they fall and are incorporated into soils. Failure to account for these time lags in living vegetation may result in an overestimate of the time required for decomposition (since the turnover time will reflect the time spent in the plant plus soil, rather than the soil alone).

\subsubsection{Systems That Are Accumulating Soil Carbon}

Again, net change in $\mathrm{C}$ storage $(\mathrm{dC} / \mathrm{dt})$ represents the balance between annual $\mathrm{C}$ inputs $(\mathrm{I} ; \mathrm{kg}$ $\left.\mathrm{C} \mathrm{m}^{-2} \mathrm{y}^{-1}\right)$ and decomposition $\left(k C\right.$, where $\mathrm{k}$ is a first-order decomposition rate constant $\left(\mathrm{y}^{-1}\right)$, and $\mathrm{C}_{\mathrm{t}}$ is the soil layer $\mathrm{C}$ inventory in $\mathrm{kg} \mathrm{C} \mathrm{m}^{-2}$ ) in year $t$. The solution to this (integrating $\mathrm{A} 2.1$ above and assuming that $\mathrm{C}$ stock $=0$ at time $t=0$ ) is:

$$
C(t)=I / k-(I / k))^{-k t}=\mathrm{I} / \mathrm{k}(1-\exp (-\mathrm{kt}))
$$

(by assuming that $C=0$ at $t=0$ we are modeling only the new $C$ that has accumulated; this is most practical in sites where the new $\mathrm{C}$ is layered distinctly from older soil organic matter. If this is not the case, the integration can be done keeping $C_{0}$ explicitly) Using historical site data or radiocarbon data to determine the time of accumulation, $t$, we can determine the history of $\mathrm{C}$ accumulation at a site. A plot of accumulated carbon inventory $\left(C_{t}\right)$ versus the time it took to accumulate ( $t$, from radiocarbon in this case) may be fit with Equation (A2.7) to derive estimates of $I$ and $k$ describing either decadal (bomb radiocarbon) or millennial (natural radiocarbon) $\mathrm{C}$ dynamics (Trumbore and Harden, 1997). An example is shown in Figure 10. Alternatively, for a 
known-age disturbance or soil age, the amount of $\mathrm{C}$ accumulated, and the amount of radiocarbon accumulated, will uniquely determine $I$ and $k$.

\subsubsection{Natural Radiocarbon (i.e. samples not affected by bomb-C)}

Prior to 1950 , the ${ }^{14} \mathrm{C}$ content of atmospheric $\mathrm{CO}_{2}$ was approximately constant relative to the magnitude of the bomb spike or to radiodecay of ${ }^{14} \mathrm{C}$ in SOM cycling on century-millennial timescales. For constant atmospheric ${ }^{14} \mathrm{C}$ content $\left(\mathrm{F}_{\mathrm{atm}}=1.0\right.$ pre-1959), $F_{C, t}$ may be expressed by including the loss terms for radiocarbon (decomposition plus radiodecay: $k+\lambda$ ) compared to carbon (decomposition only; equation A2.1):

$$
F_{C, t}=\frac{\frac{I}{(k+\lambda)}\left[1-\mathrm{e}^{(-(k+\lambda) t)}\right]}{C_{t}}
$$

where $t$ is the time since soil (or soil layers) began to form. Substituting for $C_{t}$,

$$
F_{C, t}=\frac{k}{(k+\lambda)} * \frac{\left[1-\mathrm{e}^{(-(k+\lambda) t)}\right]}{\left[1-\mathrm{e}^{(-k t)}\right]}
$$

In their study of how different soil minerals affect the long-term turnover rates of carbon in soils of Hawai'i, Torn et al. (1997) used this approach, but they incorrectly used F' rather than F and used the Libby half-life of radiocarbon. Although these mistakes had only small effects on the estimates of turnover time reported in that paper, it was this kind of confusion over approaches that led us to write this appendix. Likely far larger (but unquantifiable) errors when using the natural radiocarbon equations given here are (1) the possibility that some bomb $\mathrm{C}$ has been incorporated in any sample taken since 1950 (which would lead to underestimation of turnover times), and (2) the assumption that the carbon pools being measured are homogenous (i.e. all described by a single turnover time). 


\subsubsection{Bomb Radiocarbon}

To determine the inventory-weighted mean $\Delta^{14} \mathrm{C}$ value in 1996 , we assume annual C additions are labeled with the $\Delta^{14} \mathrm{C}$ of that year's atmospheric $\mathrm{CO}_{2}$, and track the loss of $\mathrm{C}$ and ${ }^{14} \mathrm{C}$ with time for each year's $\mathrm{C}$ input. We can ignore isotopic fractionation, and assume that respired $\mathrm{C}$ has the same ${ }^{14} \mathrm{C}$ content as the organic matter in each annual layer because of the ${ }^{13} \mathrm{C}$ correction in the radiocarbon units (See Appendix 1). The equation expressing the inventoryweighted mean ${ }^{14} \mathrm{C}$ content of the soil profile in year $t$ after initiation of accumulation is:

$$
\mathrm{F}_{\mathrm{C}, \mathrm{t}}^{\prime}=\frac{\sum_{\mathrm{i}=0}^{\mathrm{i}=\mathrm{T}} \mathrm{C}_{\mathrm{i}, \mathrm{t}} \mathrm{F}_{\mathrm{atm}, \mathrm{i}}^{\prime}}{\sum_{\mathrm{i}=0}^{\mathrm{i}=\mathrm{T}} \mathrm{C}_{\mathrm{i}, \mathrm{t}}}
$$

where $T$ is the total number of years carbon has been accumulating (years since disturbance), and $F^{\prime}{ }_{a t m, i}$ is $\mathrm{A}_{\mathrm{SN}} / \mathrm{A}_{\mathrm{abs}}$ for carbon fixed in the year $i$ (assumed to equal that year's atmospheric $\left.\Delta^{14} \mathrm{CO}_{2} / 1000+1\right)$, and $C_{i, t}=I / k\left(1-\exp ^{(-k t)}\right)$ is the carbon remaining $t$ years after it was fixed in year $i(\mathrm{t}=\mathrm{T}-\mathrm{i})$. For example, consider a layer of moss and detritus sampled in 1994 that began to accumulate 120 years prior, following a fire in a boreal forest. If the rate of $\mathrm{C}$ inputs is $120 \mathrm{~g}$ $\mathrm{C} \mathrm{m}^{-2} \mathrm{yr}^{-1}$, and the decomposition rate is $0.02 \mathrm{yr}^{-1}$ (turnover time of 50 years), the total amount of carbon accumulated in 120 years will be $5.5 \mathrm{~kg} \mathrm{C} \mathrm{m}^{-2}$, and the bulk $\Delta^{14} \mathrm{C}$ of the moss layer will be $+183 \%$. For the same input rate, but with faster decomposition $\left(0.04 \mathrm{yr}^{-1}\right.$, or turnover time of 25 years), only $3.0 \mathrm{~kg} \mathrm{C} \mathrm{m}^{-2}$ will have accumulated, with $\Delta^{14} \mathrm{C}$ of $+231 \%$. Knowing the bulk amount of $\mathrm{C}$ and its inventory-weighted $\Delta^{14} \mathrm{C}$ value for a known period of accumulation will uniquely define $I$ and $k$. Again, complications arise because of the assumption of zero time lag for $\mathrm{C}$ storage in vegetation (especially woody biomass that may represent a significant portion of 
the litter carbon in fire-dominated forest systems), but lag times can be estimated and incorporated.

\subsection{CONVERTING FROM $k$ TO $\tau$}

The relationship between the turnover time, $\tau$, and the decay rate constant, $\mathrm{k}$, used in the appendix, is a simple inverse: $\tau=1 / k$. However, care must be taken when converting between the mean value of $k$ and $\tau$ because the inverse of a mean value is not the same as the mean of inverse values (i.e., the mean $\tau$ is not the inverse of the mean $k$ ). To illustrate, consider three samples with estimated $k$ values of $0.1,0.08$, and $0.06 \mathrm{y}^{-1}$. Mean $k$ is $0.08 \mathrm{y}^{-1}$. It would be incorrect to calculate the mean $\tau$ as $1 / 0.08=12.5 \mathrm{y}$. Rather, the correct mean $\tau$ is the mean of $1 / 0.1,1 / 0.08$, and 1/0.06, which is $13 \mathrm{y}$. In other words, one must first convert each $\mathrm{k}$ value to a $\tau$ value and calculate the mean from the replicate $\tau$ values. The same is true for converting from mean $\tau$ to mean $k$. 


\section{Acknowledgment}

The work was supported by the Director, Office of Science, Office of Biological and Environmental Research, Climate Change Research Division, of the U.S. Department of Energy under Contract No. DE-AC02-05CH11231. 


\section{REFERENCES}

Aber, J.D., K.J. Nadelhoffer, P. Steudler and J.M. Melillo (1989). Nitrogen saturation in northern forest ecosystems. BioScience 39, 378-386.

Agren, G.I. and E. Bosatta (1988). Nitrogen saturation of terrestrial ecosystems. Environmental Pollution 54, 185-197.

Allardice, W., E. Begg, S. Munn and J. Mallory (1984). Laboratory data and description for some typical pedons of California soils. Volume II: Northern Coast., LAWR, UC Davis.

Allardice, W.R., S.S. Munn, E.L. Begg and J.I. Mallory (1983). Laboratory data and description for some typical pedons of California soils. Volume I: Central and Southern Sierra., LAWR, UC Davis.

Amundson, R. (2001). The Carbon Budget in Soils. Annu. Rev. of Earth and Planetary Sci. 29, 535-562.

Amundson, R. and H. Jenny (1997). On a state factor model of ecosystems. Bioscience 47, 536543.

Baisden, W.T., R. Amundson, A.C. Cook and D.L. Brenner (2002). Turnover and storage of C and $\mathrm{N}$ in five density fractions from California annual grassland surface soils. Global Biogeochemical Cycles 16, 1117.

Baker, T.R. (2004). Increasing biomass in Amazonian forest plots. Philosophical Transactions of the Royal Society of London Series B-Biological Sciences 359, 353-365.

Baldock, J.A. and J.O. Skjemstad (2000). Role of the soil matrix and minerals in protecting natural organic materials against biological attack. Organic Geochemistry 31, 697-710.

Balesdent J., Wagner G.H., and A. Mariotti (1988). Soil organic matter turnover in long-term field experiments as revealed by carbon-13 natural abundance. Soil Sci Soc Am J 52:118124.

Basile-Doelsch, I., R. Amundson, W. Stone, C.A. Masiello, J.-Y. Bottero, F. Colin, F. Masin, D. Borschneck and J.-D. Meunier (2005). Mineralogical control of organic carbon dynamics in an allophanic soil (La Reunion). European Journal of Soil Science 56, 689-703.

Batjes, N.H. (1996). Total carbon and nitrogen in the soils of the world. European Journal of Soil Science 47, 151-163.

Begg, E.L., W.R. Allardice, S.S. Munn and J.I. Mallory (1985). Laboratory data and description for some typical pedons of California soils. Volume III: Southern Cascade and Northern Sierra., LAWR, UC Davis.

Bellamy, P.H. (2005). Carbon losses from all soils across England and Wales 1978-2003. Nature 437, 245-248.

Berg, B., C. McClaugherty, A.V. De Santo and D. Johnson (2001). Humus buildup in boreal forests: effects of litter fall and its $\mathrm{N}$ concentration. Canadian Journal of Forest ResearchRevue Canadienne De Recherche Forestiere 31, 988-998.

Berhe, A.A., J. Harte, J.W. Harden and M.S. Torn (2007). The significance of the erosioninduced terrestrial carbon sink. Bioscience 57, 337-346.

Bird, J.A. and M.S. Torn (2006). Fine roots vs. needles: A comparison of $13 \mathrm{C}$ and $15 \mathrm{~N}$ dynamics in a ponderosa pine forest soil. Biogeochemistry 79, 361-382.

Bockheim, J.G. (2007). Importance of Cryoturbation in Redistributing Organic Carbon in Permafrost-Affected Soils. Soil Sci Soc Am J 71, 1335-1342. 
Boggs, J.L. (2005). Tree growth, foliar chemistry, and nitrogen cycling across a nitrogen deposition gradient in southern Appalachian deciduous forests. Canadian Journal of Forest Research-Revue Canadienne De Recherche Forestiere 35, 1901-1913.

Bohlen, P.J., P.M. Groffman, T.J. Fahey, M.C. Fisk, E. Suarez, D.M. Pelletier and R.T. Fahey (2004). Ecosystem consequences of exotic earthworm invasion of north temperate forests. Ecosystems 7, 1-12.

Boisvenue, C. and S.W. Running (2006). Impacts of climate change on natural forest productivity - evidence since the middle of the 20th century. Global Change Biology 12, 862882.

Buchanan, D. and B. Corcoran (1959). Sealed tube combustions for the determination of carbon14 and total carbon. Analytical Chemistry 31, 1635-1638.

Cairney, J.W.G. and R.M. Burke (1998). Extracellular enzyme activities of the ericoid mycorrhizal endophyte Hymenoscyphus ericae (Read) Korf \& Kernan: their likely roles in decomposition of dead plant tissue in soil. Plant and Soil 205, 181-192.

Cambardella, C.A. (1994). Carbon and nitrogen dynamics of soil organic matter fractions from cultivated grassland soils. Soil Science Society of America Journal 58, 123-130.

Cambardella, C.A. and E.T. Elliott (1992). Particulate soil organic-matter changes across a grassland cultivation sequence. Soil Science Society of America Journal 56, 777-783.

Carrasco, J.J., J.C. Neff and J.W. Harden (2006). Modeling physical and biogeochemical controls over carbon accumulation in a boreal forest soil. Journal of Geophysical ResearchBiogeosciences 111.

Castanha, C., S.E. Trumbore and R. Amundson (2008). Methods of separating soil carbon pools affect the chemistry and turnover time of isolated fractions. Radiocarbon 50, 83-97.

Chadwick, O.A., L.A. Derry, P.M. Vitousek, B.J. Huebert and L.O. Hedin (1999). Changing sources of nutrients during four million years of ecosystem development. Nature 397, 491497.

Chambers, J.Q. and W.L. Silver (2004). Some aspects of ecophysiological and biogeochemical responses of tropical forests to atmospheric change. Philosophical Transactions of the Royal Society of London Series B-Biological Sciences 359, 463-476.

Chan, K.Y. (2001). Soil particulate organic carbon under different land use and management. Soil Use and Management 17, 217-221.

Chapin, F.S., A.D. Mcguire, J. Randerson, R. Pielke, D. Baldocchi, S.E. Hobbie, N. Roulet, W. Eugster, E. Kasischke, E.B. Rastetter, S.A. Zimov and S.W. Running (2000). Arctic and boreal ecosystems of western North America as components of the climate system. Global Change Biology 6, 211-223.

Chotte, J.L., J.N. Ladd and M. Amato (1998). Sites of microbial assimilation, and turnover of soluble and particulate ${ }^{14} \mathrm{C}$-labelled substrates decomposing in a clay soil. Soil Biology \& Biochemistry 30, 205-218.

Christensen, B.T. (1992). Physical fractionation of soil and organic matter in primary particle size and density separates. Advances in Soil Science 20, 1-90.

Cisneros-Dozal, L.M., S. Trumbore and P.J. Hanson (2006). Partitioning sources of soil-respired $\mathrm{CO} 2$ and their seasonal variation using a unique radiocarbon tracer. Global Change Biology 12, 194-204.

Crow, S.E., C.W. Swanston, K. Lajtha, J.R. Brooks and H. Keirstead (2007). Density fractionation of forest soils: Methodological questions and interpretation of incubation results and turnover time in an ecosystem context. Biogeochemistry 85, 69-90. 
Davidson, E.A. and I.L. Ackerman (1993). Changes in Soil Carbon Inventories Following Cultivation of Previously Untilled Soils. Biogeochemistry 20, 161-193.

Davidson, E.A. and I.A. Janssens (2006). Temperature sensitivity of soil carbon decomposition and feedbacks to climate change. 440, 165-173.

Davidson, E.A. and P.A. Lefebvre (1993). Estimating regional carbon stocks and spatially covarying edaphic factors using soil maps at three scales. Biogeochemistry (Dordrecht) 22, 107-131.

Davidson, K.C. (2006). The woes of Kilimanjaro: The fabled glaciers on Tanzania's majestic mountain will soon be gone. Its forests are disappearing too. For local farmers, this could mean disaster. For the rest of us, it's another unbearable loss on an overheating planet. Salon.com.

Denef, K., J. Six, H. Bossuyt, S.D. Frey, E.T. Elliott, R. Merckx and K. Paustian (2001). Influence of dry-wet cycles on the interrelationship between aggregate, particulate organic matter, and microbial community dynamics. Soil Biology and Biochemistry 33, 1599-1611.

Denef, K., J. Six, R. Merckx and K. Paustian (2004). Carbon sequestration in microaggregates of no-tillage soils with different clay mineralogy. Soil Science Society of America Journal 68, 1935-1944.

Denman, K. L., G. Brasseur, A. Chidthaisong, P. Ciais, P. Cox, R. E. Dickison, D. Hauglustaine, C. Heinze, E. Holland, D. Jacob, U. Lohmann, S. Ramachandran, P. L. da Silva Dias, S. C. Wofsy and X. Zhang (2007). Couplings between changes in the climate system and biogeochemistry. Climate Change 2007: The Physical Science Basis. Contribution of Working Group I to the Fourth Assessment Report of the IPCC. Solomon, S, D. Qin, M. Manning, Z. Chen, M. Marquis, K.B. Averyt, M. Tignor, and H.L. Miller, Eds. Cambridge University Press, Cambridge, United Kingdom and New York. pp. 499-587.

Dijkstra, P., A. Ishizu, R. Doucett, S.C. Hart, E. Schwartz, O.V. Menyailo and B.A. Hungate (2006). 13C and 15N natural abundance of the soil microbial biomass. Soil Biology and Biochemistry 38, 3257-3266.

Dörr, H. and K.O. Münnich (1986). Annual variations of the ${ }^{14} \mathrm{C}$ content of soil $\mathrm{CO}_{2}$. Radiocarbon 28, 338-345.

Dunne, J.A., S.R. Saleska, M.L. Fischer and J. Harte (2004). Integrating experimental and gradient methods in ecological climate change research. Ecology 85, 904-916.

Dutta, K., E.A.G. Schuur, J.C. Neff and S.A. Zimov (2006). Potential carbon release from permafrost soils of Northeastern Siberia. Global Change Biology 12, 2336-2351.

Ellert, B.H., H.H. Janzen, and B.G. McConkey (2001). Measuring and Comparing Soil Carbon Storage pp. 131-146 in Lal, R., J.M. Kimble, R. F. Follett and B.A. Stewart. Assessment Methods for Soil Carbon. Lewis Publishers Boca Raton.

Eswaran, H., E. Van Den Berg and P. Reich (1993). Organic carbon in soils of the world. Soil Science Society of America Journal 57, 192-194.

Ewing, S.A., J. Sanderman, W.T. Baisden, Y. Wang and R. Amundson (2006). Role of largescale soil structure in organic carbon turnover: Evidence from California grassland soils. Journal of Geophysical Research-Biogeosciences 111.

Fischlin, A. and D. Gyalistras (1997). Assessing impacts of climatic change on forests in the Alps. Global Ecology and Biogeography Letters 6, 19-37.

Fischlin, A., G.F. Midgley, J.T. Price, R. Leemans, B. Gopal, M.D.A. Turley, M.D.A.

Rounsevell, O.P. Dube, J. Tarazona and A.A. Velichko (2007). Ecosystems, their properties, goods, and services. Climate Change 2007: Impacts, Adaptation, and Vulnerability. 
Contribution of Working Group II to the Fourth Assessment Report of the IPCC. M. L. Parry, O. F. Canziani, J. P. Palutikof, P. J. van der Llinden and C. E. Hanson, 211-272.

Freeman, C., C.D. Evans, D.T. Monteith, B. Reynolds and N. Fenner (2001). Export of organic carbon from peat soils. Nature 412, 785.

Fried, J.S., J.K. Gilless, W.J. Riley, T.J. Moody, C.S. de Blas, K. Hayhoe, M. Moritz, S. Stephens and M. Torn (2008). Predicting the effect of climate change on wildfire behavior and initial attack success. Climatic Change 87, S251-S264.

Friedlingstein, P. (2006). Climate-carbon cycle feedback analysis: Results from the (CMIP)-M-4 model intercomparison. Journal of Climate 19, 3337-3353.

Gaudinski, J.B., S.E. Trumbore, E.A. Davidson and S.H. Zheng (2000). Soil carbon cycling in a temperate forest: radiocarbon-based estimates of residence times, sequestration rates and partitioning of fluxes. Biogeochemistry 51, 33-69.

Gerten, D. (2004). Terrestrial vegetation and water balance - hydrological evaluation of a dynamic global vegetation model. Journal of Hydrology 286, 249-270.

Glinka, K.D. (1927). Dokuchaiev's ideas in the development of pedology and cognate sciences, USSR Academy of Sciences Russian Pedological Investigations.

Goh, K.M. (1991). Carbon dating. Carbon Isotope Techniques. D. C. Coleman and B. Fry. San Diego, Academic Press, 125-145.

Golchin, A., J.M. Oades, J.O. Skjemstad and P. Clarke (1994a). Soil structure and carbon cycling. Australian Journal of Soil Research 32, 1043-1068.

Golchin, A., J.M. Oades, J.O. Skjemstad and P. Clarke (1994b). Study of free and occluded particulate organic matter in soils by solid-state ${ }^{13} \mathrm{C}$ CP/MAS NMR spectroscopy and scanning electron microscopy. Australian Journal of Soil Research 32, 285-309.

Goulden, M.L., S.C. Wofsy, J.W. Harden, S.E. Trumbore, P.M. Crill, S.T. Gower, T. Fries, B.C. Daube, S.M. Fan, D.J. Sutton, A. Bazzaz and J.W. Munger (1998). Sensitivity of boreal forest carbon balance to soil thaw. Science (Washington D C) 279, 214-217.

Gregorich, E.G., C.M. Monreal, M. Schnitzer and H.-R. Schulten (1996). Transformation of plant residues into soil organic matter: chemical characterization of plant tissue, isolated soil fractions, and whole soils. Soil Science 161, 680-693.

Grandy, A.S. and J.C. Neff. Molecular C dynamics downstream: The biochemical decomposition sequence and its impact on soil organic matter structure and function. Science of The Total Environment, In Press, Available online 10 January 2008.

Guggenberger, G., K. Kaiser and W. Zech (1998). Mobilization and immobilization of dissolved organic matter in forest soils. Zeitschrift Fur Pflanzenernahrung Und Bodenkunde 161, 401408.

Guo, L.B. and R.M. Gifford (2002). Soil carbon stocks and land use change: a meta analysis. Global Change Biology 8, 345-360.

Hamer, U., B. Marschner, S. Brodowski and W. Amelung (2004). Interactive priming of black carbon and glucose mineralisation. Organic Geochemistry 35, 823-830.

Hanson, P.J., C.W. Swanston, C.T. Garten, Jr., D.E. Todd and S.E. Trumbore (2005). Reconciling change in Oi-horizon carbon-14 with mass loss for an oak forest. Soil Science Society of America Journal 69, 1492-1502.

Harden, J.W., J.M. Sharpe, W.J. Parton, D.S. Ojima, T.L. Fries, T.G. Huntington and S.M. Dabney (1999). Dynamic replacement and loss of soil carbon on eroding cropland. Global Biogeochemical Cycles 13, 885-901. 
Harden, J.W., E.T. Sundquist, R.F. Stallard and R.K. Mark (1992). Dynamics of soil carbon during deglaciation of the Laurentide ice sheet. Science 258.

Harden, J.W., S.E. Trumbore, B.J. Stocks, A. Hirsch, S.T. Gower, K.P. O'neill and E.S. Kasischke (2000). The role of fire in the boreal carbon budget. Global Change Biology 6 , 174-184.

Harmon, M.E., K.J. Nadelhoffer and J.M. Blair (1999). Measuring Decomposition, Nutrient Turnover, and Stores in Plant Litter. Standard Soil Methods for Long-Term Ecological Research. G. P. Robertson, C. S. Bledsoe, D. C. Coleman and P. Sollins. New York, Oxford University Press, 202-240.

Harradine, F. and H. Jenny (1958). Influence of parent material and climate on texture and nitrogen and carbon contents of virgin California soils I. Texture and nitrogen contents of soils. Soil Science 85, 235-243.

Harrison, K. (1993). A Strategy for Estimating the Impact of Co2 Fertilization on Soil Carbon Storage. Global Biogeochemical Cycles 7, 69-80.

Harrison, K.G., W.S. Broecker and G. Bonani (1993). The effect of changing land use on soil radiocarbon. Science (Washington D C) 262, 725-726.

Hart, S.C., G.E. Nason, D.D. Myrold and D.A. Perry (1994). Dynamics of gross nitrogen transformations in an old-growth forest: the carbon connection. Ecology 75, 880-891.

Hassan, R., R. Scholes and N. Ash, Eds. (2005). Ecosystems and human well-being. The Millenium Ecosystem Assessment series. Washington, D.C., Island Press.

Holdridge, L.R. (1947). Determination of World plant formations from simple climatic data. Science (Washington D C) 105, 367-368.

IPCC (2007). Climate Change 2007: The Physical Science Basis. Contribution of Working Group I to the Fourth Assessment Report of the IPCC. Solomon, S, D. Qin, M. Manning, Z. Chen, M. Marquis, K.B. Averyt, M. Tignor, and H.L. Miller (Eds). Cambridge University Press, Cambridge, United Kingdom and New York, NY, USA. 996 pp.

Jacinthe, P.A. and R. Lal (2001). Mass Balance Approach to Asssess Carbon Dioxide Evolution During Erosional Events. 12, 329-339.

Jahn, R., M. Zarei and K. Stahr (1992). Development of andic soil properties and of clay minerals in the semiarid climate of Lanzarote (Spain). Mineralogica et Petrographica Acta XXXV- A, 193- 201.

Jastrow, J.D., R.M. Miller and J. Lussenhop (1998). Contributions of interacting biological mechanisms to soil aggregate stabilization in restored prairie. Soil Biology \& Biochemistry 30, 905-916.

Jastrow, J.D., R.M. Miller, R. Matamala, R.J. Norby, T.W. Boutton, C.W. Rice and C.E. Owensby (2005). Elevated atmospheric carbon dioxide increases soil carbon. Global Change Biology 11, 2057-2064.

Jenny, H. (1930). A Study on the Influence of Climate Upon the Nitrogen and Organic Matter Content of the Soil. Columbia, MO, University of Missouri College of Agriculture.

Jenny, H. (1941). Factors of Soil Formation. New York, Dover Publications Inc.

Jenny, H. (1980). The Soil Resource: origin and behaviour. New York, Springer-Verlag.

Jobbagy, E.G. and R.B. Jackson (2000). The vertical distribution of soil organic carbon and its relation to climate and vegetation. Ecological Applications 10, 423-436.

Kiem, R. and I. Kogel-Knabner (2003). Contribution of lignin and polysaccharides to the refractory carbon pool in C-depleted arable soils. Soil Biology \& Biochemistry 35, 101-118. 
Kirschbaum, M.U.F. (2000). Will changes in soil organic carbon act as a positive or negative feedback on global warming? Biogeochemistry 48, 21-51.

Kleber, M., R. Mikutta, M.S. Torn and R. Jahn (2005). Poorly crystalline mineral phases protect organic matter in acid subsoil horizons. European Journal of Soil Science 56, 717-725.

Kleber, M., P. Sollins and R. Sutton (2007). A conceptual model of organo-mineral interactions in soils: Self-assembly of organic molecular fragments into zonal structures on mineral surfaces. Biogeochemistry.

Kögel-Knabner, I., W. Zech, P.G. Hatcher and J.W. deLeeuw (1991). Fate of plant components during biodegradation and humification in forest soils: Evidence from structural characterization of individual biomacromolecules. Advances in Soil and Organic Matter Research: The Impact of Agriculture and the Environment. W. S. Wilson, Royal Society of Chemistry, London. 90, 61-70.

Kong, A.Y.Y., J. Six, D.C. Bryant, R.F. Denison and C. van Kessel (2005). The relationship between carbon input, aggregation, and soil organic carbon stabilization in sustainable cropping systems. Soil Science Society of America Journal 69, 1078-1085.

Kramer, M.G., P. Sollins and R.S. Sletten (2004). Soil carbon dynamics across a windthrow disturbance sequence in southeast Alaska. Ecology 85, 2230-2244.

Krull, E.S., J.A. Baldock and J.O. Skjemstad (2003). Importance of mechanisms and processes of the stabilisation of soil organic matter for modelling carbon turnover. Functional Plant Biology 30, 207-222.

Krull, E.S., C.W. Swanston, J.O. Skjemstad and J.A. McGowan (2006). The importance of charcoal in determining the age and chemistry of organic carbon in surface soils. Journal of Geophysical Research - Biogeochemistry 111, doi:10.1029/2006JG000194.

Kuzyakov, Y. (2006). Sources of CO2 efflux from soil and review of partitioning methods. Soil Biology and Biochemistry 38, 425-448.

Kuzyakov, Y. and A.A. Larionova (2005). Root and rhizomicrobial respiration: A review of approaches to estimate respiration by autotrophic and heterotrophic organisms in soil. Journal of Plant Nutrition and Soil Science 168, 503-520.

Lal, R. and J.P. Bruce (1999). The potential of world cropland soils to sequester C and mitigate the greenhouse effect. Environmental Science and Policy 2, 177-185.

Lapenis, A.G., M.S.Torn, J.W. Harden, K. Hollocker, B.V. Babikov, A.I. Timofeev, M.I. Hornberger and R. Nattis (2000). Scientists Unearth Clues to Soil Contamination by Comparing Old and New Soil Samples. EOS 81, 55-57.

Lewis, S.L. (2004). Concerted changes in tropical forest structure and dynamics: evidence from 50 South American long-term plots. Philosophical Transactions of the Royal Society of London Series B-Biological Sciences 359, 421-436.

Lützow, M.v., I. Kogel-Knabner, K. Ekschmitt, E. Matzner, G. Guggenberger, B. Marschner and H. Flessa (2006). Stabilization of organic matter in temperate soils: mechanisms and their relevance under different soil conditions - a review. European Journal of Soil Science 57, 426-445.

Mack, M.C., E.A.G. Schuur, M.S. Bret-Harte, G.R. Shaver, and F.S. Chapin III (2004), Ecosystem carbon storage in arctic tundra reduced by long-term nutrient fertilization, Nature, $431,440-443$. 
Malhi, Y. and O.L. Phillips (2004). Tropical forests and global atmospheric change: a synthesis. Philosophical Transactions of the Royal Society of London B Biological Sciences 359, 549555.

Marti, C. and D. Badia (1995). Characterization and classification of soil along two altitudinal transects in the eastern Pynenees, Spain. Arid Soil Research and Rehabilitation 9, 367-383.

Masiello, C.A., O.A. Chadwick, J. Southon, M.S. Torn and J.W. Harden (2004). Weathering controls on mechanisms of carbon storage in grassland soils. Global Biogeochemical Cycles 18, GB4023.

Matthews, E. (1997). Global litter production, pools, and turnover times: Estimates from measurement data and regressions models Journal of Geophysical Research 102, 1877118800.

Mayer, L.M., L.L. Schick, K.R. Hardy, R. Wagai and J. McCarthy (2004). Organic matter in small mesopores in sediments and soils. Geochimica et Cosmochimica Acta 68, 3863-3872.

Melillo, J.M., J.D. Aber and J.F. Muratore (1982). Nitrogen and lignin control of hardwood leaf litter decomposition dynamics. Ecology 63, 621-626.

Melillo, J.M., D.W. Kicklighter, A.D. McGuire, W.T. Peterjohn and K.M. Newkirk (1995). Global changes and is effects on soil organic carbon stocks. Environmental Sciences Research Report; The role of nonliving organic matter in the Earth's carbon cycle. R. G. Zepp and C. Sonntag, John Wiley and Sons Ltd., Baffin Lane, Chichester PO 19 1UD, England, John Wiley and Sons, Inc., 605 Third Avenue, New York, New York 10158-0012, USA, 175-189.

Miglierina, A.M. and R.A. Rosell (1995). Humus quantity and quality of an entic haplustoll under different soil-crop management systems. Communications in Soil Science and Plant Analysis 26, 3343-3355.

Mikutta, R., M. Kleber, M.S. Torn and R. Jahn (2006). Stabilization of soil organic matter: Association with minerals or chemical recalcitrance? Biogeochemistry 77, 25-56.

Moore, T.R., J.L. Bubier and L. Bledzki (2007). Litter decomposition in temperate peatland ecosystems: The effect of substrate and site. Ecosystems 10, 949-963.

Moran, K.K., J. Six, W.R. Horwath and C. Van Kessel (2005). Role of mineral-nitrogen in residue decomposition and stable soil organic matter formation. Soil Science Society of America Journal 69, 1730-1736.

Myers, N. (2000). Biodiversity hotspots for conservation priorities. Nature 403, 853-858.

Nadelhoffer, K.J. (1990). Microlysimeter for Measuring Nitrogen Mineralization and Microbial Respiration in Aerobic Soil Incubations. Soil Science Society of America Journal 54, 411415.

Nemani, R.R. (2003). Climate-driven increases in global terrestrial net primary production from 1982 to 1999. Science 300, 1560-1563.

Nepstad, D.C., C.R. de Carvalho, E.A. Davidson, P.H. Jipp, P.A. Lefebvre, G.H. Negreiros, E.D. da Silva, T.A. Stone, S.E. Trumbore and S. Vieira (1994). The role of deep roots in the hydrological and carbon cycles of Amazonian forests and pastures. Nature 372, 666-669.

Norton, J.M. (1990). Carbon Flow in the Rhizosphere of Ponderosa Pine-Seedlings. Soil Biology \& Biochemistry 22, 449-455.

Oades, J.M. (1984). Soil organic matter and structural stability: mechanisms and implications for management. Plant \& Soil 76, 319-337.

Oades, J.M. (1988). The retention of organic matter in soils. Biogeochemistry 5, 35-70. 
Oades, J.M. (1989). An introduction to organic matter in mineral soils. Minerals in Soil Environments. J. B. Dixon and S. B. Weed. Madison, WI, USA, SSSA, 89-153.

Osono, T., H. Takeda and J.-i. Azuma (2008). Carbon isotope dynamics during leaf litter decomposition with reference to lignin fractions. Ecological Research 23, 51-55.

Parton, W., W.L. Silver, I.C. Burke, L. Grassens, M.E. Harmon, W.S. Currie, J.Y. King, E.C. Adair, L.A. Brandt, S.C. Hart and B. Fasth (2007). Global-Scale Similarities in Nitrogen Release Patterns During Long-Term Decomposition. Science 315, 361-364.

Paul, E.A., H.P. Collins and S.W. Leavitt (2001). Dynamics of resistant soil carbon of Midwestern agricultural soils measured by naturally occurring $14 \mathrm{C}$ abundance. Geoderma 104, 239-256.

Paul, E.A., S.J. Morris, R.T. Conant and A.F. Plante (2006). Does the acid hydrolysis-incubation method measure meaningful soil organic carbon pools? Soil Science Society of America Journal 70, 1023-1035.

Percival, H.J., R.L. Parfitt and N.A. Scott (2000). Factors controlling soil carbon levels in New Zealand grasslands: Is clay content important? Soil Science Society of America Journal 64, 1623-1630.

Post, W.M., D.W. Anderson, A. Dahmke, R.A. Houghton, A.-Y. Huc, R. Lassiter, R.G. Najjar, H.-U. Neue, T.F. Pedersen, S.E. Trumbore and R. Vaikmae (1995). Group report: What is the role of nonliving organic matter cycling on the global scale? Environmental Sciences Research Report; The role of nonliving organic matter in the Earth's carbon cycle. R. G. Zepp and C. Sonntag, John Wiley and Sons Ltd., Baffin Lane, Chichester PO 19 1UD, England, John Wiley and Sons, Inc., 605 Third Avenue, New York, New York 10158-0012, USA, 155-174.

Post, W.M., W.R. Emanuel, P.J. Zinke and A.G. Stangenberger (1982). Soil carbon pools and world life zones. 298, 156-159.

Potter, C.S., J.T. Randerson, C.B. Field, P.A. Matson, P.M. Vitousek, H.A. Mooney and S.A. Klooster (1993). Terrestrial ecosystem production: A process model based on global satellite and surface data. Global Biogeochemical Cycles 7, 811-841.

Preston, C.M. and M.W.I. Schmidt (2006). Black (pyrogenic) carbon: A synthesis of current knowledge and uncertainties with special consideration of boreal regions. Biogeosciences $\mathbf{3}$, 397-420.

Quideau, S.A. (1998). Organic carbon sequestration under chaparral and pine after four decades of soil development. Geoderma 83, 227-242.

Quideau, S.A., O.A. Chadwick, A. Benesi, R.C. Graham and M.A. Anderson (2001). A direct link between forest vegetation type and soil organic matter composition. Geoderma 104, 4160.

Raich, J.W. and C.S. Potter (1995). Global patterns of carbon dioxide emissions from soils. Global Biogeochemical Cycles 9, 23-36.

Raich, J.W., A.E. Russell, K. Kitayama, W.J. Parton and P.M. Vitousek (2006). Temperature influences carbon accumulation in moist tropical forests. Ecology (Washington D C) 87, 7687.

Raich, J.W. and W.H. Schlesinger (1992). The Global Carbon Dioxide Flux in Soil Respiration and Its Relationship to Vegetation and Climate. Tellus Series B Chemical and Physical Meteorology 44, 81-99. 
Rasmussen, C., M.S. Torn and R.J. Southard (2005). Mineral assemblage and aggregates control carbon dynamics in a California conifer forest. Soil Science Society of America Journal 69, 1711-1721.

Reichstein, M., J.-A. Subke, A.C. Angeli and J.D. Tenhunen (2005). Does the temperature sensitivity of decomposition of soil organic matter depend upon water content, soil horizon, or incubation time? Global Change Biology 11, 1754-1767.

Rillig, M.C., B.A. Caldwell, H.A.B. Wösten and P. Sollins (2007). Role of proteins in soil carbon and nitrogen storage: controls on persistence. Biogeochemistry 85, 25-44.

Rodhe, H. (1992). Modeling biogeochemical cycles. Global Biogeochemical Cycles. S. S. Butcher, R. J. Charlson, G. H. Orians and G. V. Wolfe. San Diego, Academic Press, Inc., 5572.

Sabine, C.L., M. Heimann, P. Artaxo, D.C.E. Bakker, C.T.A. Chen, C.B. Field and N. Gruber (2004). Current status and past trends of the global carbon cycle. The global carbon cycle: integrating humans, climate, and the natural world C. B. Field and M. R. Raupach. Washington, D.C., Island Press.

Saleska, S.R., M.R. Shaw, M.L. Fischer, J.A. Dunne, C.J. Still, M.L. Holman and J. Harte (2002). Plant community composition mediates both large transient decline and predicted long term recovery of soil carbon under climate warming. Global Biogechemical Cycles 16, 1055.

Schimel, D.S. (1995). Terrestrial ecosystems and the carbon cycle. Global Change Biology 1, 77-91.

Schimel, D.S., B.H. Braswell, E.A. Holland, R. McKeown, D.S. Ojima, T.H. Painter, W.J. Parton and A.R. Townsend (1994). Climatic, edaphic, and biotic controls over storage and turnover of carbon soils. Global Biogeochemical Cycles 8, 279-293.

Schlesinger, W.H. (1977). Carbon balance in terrestrial detritus. Annual Review of Ecology and Systematics 8, 51-81.

Schlesinger, W.H. (1990). Evidence from Chronosequence Studies for a Low Carbon-Storage Potential of Soils. Nature (London) 348, 232-234.

Schmidt, M.W.I. and I. Kogel-Knabner (2002). Organic matter in particle-size fractions from A and B horizons of a Haplic Alfisol. European Journal of Soil Science 53, 383-391.

Schmidt M.W.I., Noack A.G. (2000). Black carbon in soils and sediments: Analysis, distribution, implications, and current challenges. Global Biogeochemical Cycles 14, 777-794.

Shaver, G.R., J. Canadell, F.S.I. Chapin, J. Gurevitch, J. Harte, G. Henry, P. Ineson, S. Jonasson, J. Melillo, L. Pitelka and L. Rustad (2000). Global warming and terrestrial ecosystems: A conceptual framework for analysis. BioScience 50, 871-882.

Silver, W.L., R. Ostertag and A.E. Lugo (2000). The Potential for Carbon Sequestration Through Reforestation of Abandoned Tropical Agricultural and Pasture Lands. Restoration Ecology 8 , 394-407.

Silvertown, J. (2006). The Park Grass Experiment 1856-2006: Its contribution to ecology. Journal of Ecology 94, 801-814.

Sitch, S. (2003). Evaluation of ecosystem dynamics, plant geography and terrestrial carbon cycling in the LPJ dynamic global vegetation model. Global Change Biology 9, 161-185.

Six, J., P. Callewaert, S. Lenders, S. De Gryze, S.J. Morris, E.G. Gregorich, E.A. Paul and K. Paustian (2002). Measuring and understanding carbon storage in afforested soils by physical fractionation. Soil Science Society of America Journal 66, 1981-1987. 
Six, J., E.T. Elliott and K. Paustian (1999). Aggregate and soil organic matter dynamics under conventional and no-tillage systems. Soil Science Society of America Journal 63, 1350-1358.

Six, J., E.T. Elliott and K. Paustian (2000a). Soil macroaggregate turnover and microaggregate formation: A mechanism for $\mathrm{C}$ sequestration under no-tillage agriculture. Soil Biology and Biochemistry 32, 2099-2103.

Six, J., R. Merckx, K. Kimpe, K. Paustian and E.T. Elliott (2000b). A re-evaluation of the enriched labile soil organic matter fraction. European Journal of Soil Science 51, 283-293.

Smith, L.C., G.M. MacDonald, A.A. Velichko, D.W. Beilman, O.K. Borisova, K.E. Frey, K.V. Kremenetski and Y. Sheng (2004). Siberian Peatlands a Net Carbon Sink and Global Methane Source Since the Early Holocene. Science 303, 353-356.

Smith, S.V., R.O. Sleezer, W.H. Renwick and R. Buddemeier (2005). Fates of eroded soil organic carbon: Mississippi basin case study. Ecological Applications 15, 1929-1940.

Sollins, P., C.A. Glassman, E.A. Paul, C. Swanston, K. Lajtha, J.W. Heil and E.T. Elliott (1999). Soil Carbon and Nitrogen: Pools and Fractions. Standard Soil Methods for Long-Term Ecological Research. C. S. B. G. P. Robertson, D. C. Coleman and P. Sollins. New York, Oxford University Press, 89-105.

Sollins, P., P. Homann and B.A. Caldwell (1996). Stabilization and destabilization of soil organic matter: Mechanisms and controls. Geoderma 74, 65-105.

Sollins, P., C. Swanston, M. Kleber, T. Filley, M. Kramer, S. Crow, B.A. Caldwell, K. Lajtha and R. Bowden (2006). Organic C and N stabilization in a forest soil: Evidence from sequential density fractionation. Soil Biology and Biochemistry 38, 3313-3324.

Sombroek, W.G., F.O. Nachtergaele and A. Hebel (1993). Amounts, dynamics and sequestering of carbon in tropical and subtropical soils. Ambio 22, 417-426.

Stallard, R.F. (1998). Terrestrial sedimentation and the carbon cycle: Coupling weathering and erosion to carbon burial. Global Biogeochemical Cycles 12, 231-257.

Steinmann, K., R.T.W. Siegwolf, M. Saurer and C. Korner (2004). Carbon fluxes to the soil in a mature temperate forest assessed by 13C isotope tracing. Oecologia 141, 489-501.

Stevenson, F.J. (1994). Clay-organic complexes and formation of stable aggreggates. Humus chemistry: genesis, composition, reactions. New York, John Wiley \& Sons, Inc., 429-452.

Still, C. J., Berry, J. A., Collatz, G. J., and R.S. DeFries (2003). Global distribution of $\mathrm{C}_{3}$ and $\mathrm{C}_{4}$ vegetation: carbon cycle implications. Global Biogeochemical Cycles, 6.1-6.14

Stork, N.E. and P. Eggleton (1992). Invertebrates as determinants and indicators of soil quality. American Journal of Alternative Agriculture 7, 38-47.

Stotzky, G. (1965). Microbial respiration. Methods of Soil Analysis. Part 2. Agronomy Monograph No. 9. C. A. Black. Madison, WI, ASA.

Strickland, T.C. (1987). Improved Method for Separating Light and Heavy-Fraction Organic Material from Soil. Soil Science Society of America Journal 51, 1391-1392.

Strong, D.T., H.D. Wever, R. Merckx and S. Recous (2004). Spatial location of carbon decomposition in the soil pore system. European Journal of Soil Science 55, 739-750.

Stuiver, M. and H.A. Polach (1977). Reporting of 14C data. Radiocarbon 19, 355-363.

Swanston, C., P.S. Homann, B.A. Caldwell, D.D. Myrold, L. Ganio and P. Sollins (2004). Longterm effects of elevated nitrogen on forest soil organic matter stability. Biogeochemistry 70, 229-252.

Swanston, C.W., B.A. Caldwell, P.S. Homann, L. Ganio and P. Sollins (2002). Carbon dynamics during a long-term incubation of separate and recombined density fractions from seven forest soils. Soil Biology and Biochemistry 34, 1121-1130. 
Swanston, C.W., M.S. Torn, P.J. Hanson, J.R. Southon, C.T. Garten, E.M. Hanlon and L. Ganio (2005). Initial characterization of processes of soil carbon stabilization using forest standlevel radiocarbon enrichment. Geoderma 128, 52-62.

Thornton, P.E. and N.A. Rosenbloom (2005 ). Ecosystem model spin-up: Estimating steady state conditions in a coupled terrestrial carbon and nitrogen cycle model. Ecological Modelling 189, 25-48.

Tiessen, H. and J.W.B. Stewart (1983a). Particle-size fractions and their use in studies of soil organic matter. II. Cultivation effects on organic matter composition in size fractions. Soil Science Society of America Journal 47, 509-514.

Tiessen, H. and J.W.B. Stewart (1983b). Particle Size Fractions and Their Use in Studies of Soil Organic Matter 2. Cultivation Effects on Organic Matter Composition in Size Fractions. Soil Science Society of America Journal 47, 509-514.

Tisdall, J.M. and J.M. Oades (1982). Organic Matter and Water Stable Aggregates in Soils. Journal of Soil Science 33, 141-164.

Torn, M.S., S.E. Trumbore, O.A. Chadwick, P.M. Vitousek and D.M. Hendricks (1997). Mineral control of soil organic carbon storage and turnover. Nature (London) 389, 170-173.

Torn, M.S., Lapenis, A.G., Timofeev, A. Fischer, M., Babikov, I., and J. Harden (2002). Organic carbon and carbon isotopes in modern and 100-year-old soil archives of the Russian steppe. Global Change Biology, 8, 941-953.1

Torn, M.S., P.M. Vitousek and S.E. Trumbore (2005). The influence of nutrient availability on soil organic matter turnover estimated by incubations and radiocarbon modeling. Ecosystems 8, 352-372.

Torn, M.S. and J. Harte (2006). Missing feedbacks, asymmetric uncertainties, and the underestimation of future warming. Geophys. Res. Lett., 33, L10703, doi:10.1029/2005GL025540.

Townsend, A.R., P.M. Vitousek and S.E. Trumbore (1995). Soil organic matter dynamics along gradients in temperature and land use on the island of Hawaii. Ecology 76, 721-733.

Trumbore, S.E. (2000). Age of soil organic matter and soil respiration: Radiocarbon constraints on belowground C dynamics. Ecological Applications 10, 399-411.

Trumbore, S.E. (1993). Comparison of carbon dynamics in tropical and temperate soils using radiocarbon measurements. Global Biogeochemical Cycles 7, 275-290.

Trumbore, S.E. (1996). Measurement of cosmogenic isotopes by accelerator mass spectrometry: applications to soil science. Applications of Accelerator Mass Spectrometry. T. Boutton and S. Yamasaki. New York, Marcel Dekker, 311-340.

Trumbore, S.E., O.A. Chadwick and R. Amundson (1996). Rapid exchange between soil carbon and atmospheric carbon dioxide drived by temperature change. Science (Washington DC) 272, 393-396.

Trumbore, S.E., E.A. Davidson, P. Barbosa de Camargo, D.C. Nepstad and L.A. Martinelli (1995). Belowground cycling of carbon in forests and pastures of Eastern Amazonia. Global Biogeochemical Cycles 9, 515-528.

Trumbore S.E., Gaudinski J.B., Hanson P.J., and J.R. Southon (2002) Quantifying ecosystematmosphere carbon exchange with a ${ }^{14} \mathrm{C}$ label. Eos, Transactions, American Geophysical Union, 83, 265-268.

Trumbore, S.E. and S. Zheng (1996). Comparison of fractionation methods for soil organic matter ${ }^{14} \mathrm{C}$ analysis. Radiocarbon 38, 219-229. 
van Oost, K., T.A. Quine, G. Govers, S.d. Gryze, J. Six, J.W. Harden, J.C. Ritchie, G.W. McCarty, G. Heckrath, C. Kosmas, J.V. Giraldez, J.R.M.d. Silva and R. Merckx (2007). The impact of agricultural soil erosion on the global carbon cycle. Science (Washington) $\mathbf{3 1 8}$, 626-629.

Van Veen, J.A. and P.J. Kuikman (1990). Soil structural aspects of decomposition of organic matter by micro-organisms. Biodegradation 11, 213-233.

Veldkamp E. (1994). Organic carbon turnover in 3 tropical soils under pasture after deforestation. Soil Sci Am J 58,175-180.

Verhoef, H.A. and L. Brussaard (1990). Decomposition and nitrogen mineralization in natural and agroecosystems: the contribution of soil animals. Biodegradation 11, 175-211.

Vetter, Y.A., J.W. Deming, P.A. Jumars and B.B. Krieger-Brockett (1998). A predictive model of bacterial foraging by means of freely released extracellular enzymes. Microbial Ecology 36, 75-92.

Vogel, J.S., Southon, J.R., Nelson, D.E., and T.A. Brown (1984). Performance of catalytically condensed carbon for use in accelerator mass-spectrometry nuclear instrumentation methods. Physical Reviews, Section B. Beam Interaction Material Atmosphere 233, 289-293.

Waldrop, M.P. and D.R. Zak (2006). Response of Oxidative Enzyme Activities to Nitrogen Deposition Affects Soil Concentrations of Dissolved Organic Carbon. Ecosystems 9, 921933.

Whalen, J.K., P.J. Bottomley and D.D. Myrold (2000). Carbon and nitrogen mineralization from light- and heavy-fraction additions to soil. Soil Biology and Biochemistry 32, 1345-1352.

Wolters, V. (2000). Invertebrate control of soil organic matter stability. Biology and Fertility of Soils 31, 1-19.

Yoo, K., R. Amundson, A.M. Heimsath and W.E. Dietrich (2006). Spatial patterns of soil organic carbon on hillslopes: Integrating geomorphic processes and the biological $\mathrm{C}$ cycle. Geoderma 130, 47-65.

Zak, D.R., D.F. Grigal and L.F. Ohmann (1993). Kinetics of microbial respiration and nitrogen mineralization in Great Lakes forests. Soil Science Society of America Journal 57, 11001106.

Zanelli, R., M. Egli, A. Mirabella, D. Giaccai and P. Fitze (2006). Influence of laurophyllous species, Castanea sativa and Quercetum-Betuletum vegetation on organic matter in soils in southern Switzerland and northern Italy. Geoderma 136, 723-737.

Zepp, R.G., T.V. Callaghan and D.J. Erickson III (2003). Interactive effects of ozone depletion and climate change on biogeochemical cycles. Photochemical and Photobiological Sciences 2, 51-61.

Zhang, D., D. Hui, Y. Luo and G. Zhou (2008). Rates of litter decomposition in terrestrial ecosystems: global patterns and controlling factors. J Plant Ecol 1, 85-93.

Zimmermann, M., J. Leifeld, S. Abiven, M.W.I. Schmidt, and J. Fuhrer (2007). Sodium hypochlorite separates an older soil organic matter fraction than acid hydrolysis. Geoderma $139,171-179$.

Zimov, S.A., E.A.G. Schuur and F.S. Chapin Iii (2006). Permafrost and the Global Carbon Budget. Science 312, 1612-1613.

Zinke, P.J., A.G. Stangenberger, W.M. Post, W.R. Emmanuel and J.S. Olson (1984). Worldwide organic soil carbon and nitrogen data, Oak Ridge National Laboratory Carbon Dioxide Analysis and Information Center (CDIAC). 


\section{FIGURE CAPTIONS}

Figure 1. Ecosystem area and soil carbon content to $3 \mathrm{~m}$ depth (From Fischlin et al. 2007 in IPCC 2007). Lower Panel: Global areal extent of major ecosystems, transformed by land use in yellow, untransformed in purple. Data from Hassan et al. (2005) except for Mediterraneanclimate ecosystems, transformation impact is from Myers et al. (2000) and ocean surface area is from Hassan et al. (2005). Upper Panel: Total C stores in plant biomass (green), soil (brown), yedoma/permafrost (light blue). $\mathrm{D}=$ deserts, $\mathrm{G} \& \mathrm{~S}(\mathrm{tr})=$ tropical grasslands and savannas, $\mathrm{G}(\mathrm{te})=$ temperate grasslands, $\mathrm{ME}=$ Mediterranean ecosystems, $\mathrm{F}(\mathrm{tr})=$ tropical forests, $\mathrm{F}(\mathrm{te})=$ temperate forests, $\mathrm{F}(\mathrm{b})=$ boreal forests, $\mathrm{T}=$ tundra, $\mathrm{FW}=$ freshwater lakes and wetlands, $\mathrm{C}=$ croplands, $\mathrm{O}$ = oceans. Data are from Sabine et al. (2004), except C content of yedoma permafrost and permafrost (light blue columns, left and right, respectively (Zimov et al., 2006) and ocean organic C content (dissolved plus particulate organic; (Denman et al. 2007). This figure considers soil C to $3 \mathrm{~m}$ depth (Jobbágy and Jackson, 2000). Approximate carbon content of the atmosphere is indicated by the dotted lines for last glacial maximum (LGM), pre-industrial (PIND) and current (about 2000).

Figure 2. (A) Variations in $\% \mathrm{~N}$ (which is proportional to $\mathrm{C}$ density) with precipitation along the $11^{\circ} \mathrm{C}$ isotherm in the Great Plains of the United States. The humidity factor (NSQ, Niederschlag-Sattigungsdefizit from the German, or Meyer's quotient) is the total annual precipitation (mm) divided by the absolute saturation deficit of air ( $\mathrm{mm}$ mercury). All soils were developed on loess deposits from the last glacial maximum. (B) Change in $\% \mathrm{~N}$ with precipitation along the $19^{\circ} \mathrm{C}$ isotherm. Note that relative $\mathrm{C}$ density (estimated by assuming that the $\mathrm{C} / \mathrm{N}$ ratio of SOM is fairly constant) is lower at higher mean annual temperature (Jenny 1941). 
Figure 3. Variation of organic carbon density with texture, in surface soils developed on glacial till and loess in Iowa. Soils with more loess have finer texture (data are from Brown, 1936, as reported in Jenny, 1941).

Figure 4. Soil organic carbon inventory to $1 \mathrm{~m}$ depth by parent material category, for California and globally. Well-drained soils in California (white bars) are from the SoilVegetation Survey data set, $\mathrm{n}=568$, well-drained soils only. Worldwide data (gray bars) are from Zinke et al. (1984), n=2995, which includes the California Soil-Vegetation Survey data, all drainage classes.

Figure 5. Changes in soil organic $\mathrm{C}$ storage and mineral content along a chronosequence in Hawai'i (Torn et al., 1997). The substrate for soil development are basaltic ash deposits of known age. Climate and vegetation are virtually the same across the sites. (A) Soil organic C inventory versus ash substrate age. The solid line is the whole mineral soil to the $\mathrm{C}$ horizon, the dashed line is the top $20 \mathrm{~cm}$. The increase and subsequent decrease in SOM with soil age is mostly due to changes in the sub-surface mineral soil. (B) The correlation of soil carbon in mineral horizons with the amount of non-crystalline minerals.

Figure 6. Illustration of how turnover time and soil fluxes may be hard to estimate using radiocarbon data. Consider a bulk soil with $10 \mathrm{~kg} \mathrm{C} \mathrm{m}^{-2}$ with a ${ }^{14} \mathrm{C}$ content equivalent to a turnover time of 2,770 y (0.749 fraction Modern, $\mathrm{F}^{14} \mathrm{C}$, which gives a conventional ${ }^{14} \mathrm{C}$ age of 2320 yr; see Appendices 1 and 2). Case 1 models the soil as a single, homogeneous reservoir. The annual flux in or out of the reservoir at steady state, Flux $=10,000 \mathrm{~g} \mathrm{~m}^{-2} / 2,770 \mathrm{y}=3.6 \mathrm{~g} \mathrm{~m}^{-2}$ $\mathrm{y}^{-1}$. In Case 2, the soil organic matter is assumed to be a two-component mixture with $60 \%$ of the $\mathrm{C}$ in one pool and $40 \%$ in the other. To produce the same total ${ }^{14} \mathrm{C}$ content, the larger pool would have a turnover time of $20 \mathrm{y}$, and the smaller pool a turnover time of $13,700 \mathrm{y}$. The overall ${ }^{14} \mathrm{C}$ 
content is the same as in Case 1 , but the annual flux is now Flux $=\left(6000 \mathrm{~g} \mathrm{~m}^{-2} / 20 \mathrm{y}\right)+(4000 \mathrm{~g}$ $\left.\mathrm{m}^{-2} / 13,700 \mathrm{y}\right)=300.3 \mathrm{~g} \mathrm{~m}^{-2} \mathrm{y}^{-1}$. The age of respired $\mathrm{CO}_{2}$ would be $\sim 20$ years. Clearly, these two cases have large differences in predicted fluxes and in their implications about how fast the system will respond to changes in inputs or decomposition rates, for example associated with land use or climate change.

Figure 7. Simplifed soil carbon cycling scheme. Major inputs (plant litter) to and outputs (respiration and erosion) from the soil carbon reservoir. The observed flux of $\mathrm{C}$ out of the soil can be modeled by assuming three pools of carbon - an active pool with a turnover time on the order of years, and intermediate pool with a turnover time on the order of decades to centuries, and a passive pool with a turnover time on the order of millennia. The decomposition constant, $\mathrm{k}=1 / \tau$. Subscripts $a, i$, and $p$ refer to the active, intermediate, and passive C pools, respectively. Adapted from Amundson (2001).

Figure 8. Change in atmospheric ${ }^{14} \mathrm{C}$ with time in the northern hemisphere (heavy solid line) since 1955. Radiocarbon values are expressed as the per mil variation in ${ }^{14} \mathrm{C} /{ }^{12} \mathrm{C}$ ratio relative to a standard (see Appendix for definition of units). The lighter lines show the evolution of ${ }^{14} \mathrm{C}$ for homogeneous, steady-state reservoirs with turnover times of 5, 15, 60, and 120 years.

Figure 9. Modeled time series of global C stocks assumed to start at 1,500 Pg C, following a one-time $10 \%$ increase in NPP from 60 to $66 \mathrm{Pg} \mathrm{C} \mathrm{y}^{-1}$. The blue line represents a single pool scenario in which all soil $\mathrm{C}$ has a residence time, $\tau$ of 25 years. This residence time is derived from the mass balance equation shown in Section $3, \mathrm{~d} C / \mathrm{d} t=\mathrm{NPP}-\mathrm{C} / \tau$, and assuming steady state (such that inputs equal outputs). The blue line represents a two-pool scenario in which 70 percent of the incoming $\mathrm{C}$ has a residence time, $\tau=35 \mathrm{y}$ and 30 percent has a $\tau=2$ years, such that the overall residence or "bulk" $\tau=25$ years. Because it contains a slower cycling pool, the 
two-pool model accumulates $\mathrm{C}$ faster and takes longer to reach a new steady state equilibrium, with much higher $\mathrm{C}$ stocks than the single pool model.

Figure 10. Accumulation of $\mathrm{C}$ in non-steady state soils of a mature black spruce/moss forest in central Manitoba, Canada. Data shown are (A) for Sphagnum moss that has accumulated since the site last burned ( 100 years before sampling), and (B) for the humus and charred layer below the regrowing moss and including the A horizon. The soil is developed on the sediments of a lake that dried up 7,000 years ago. The parameters $I=$ plant input $\left(\mathrm{kg} \mathrm{C} \mathrm{m}^{-2} \mathrm{y}^{-1}\right)$ and $k=$ decomposition constant $\left(\mathrm{y}^{-1}\right)$. From Trumbore and Harden (1997). 
Figures 


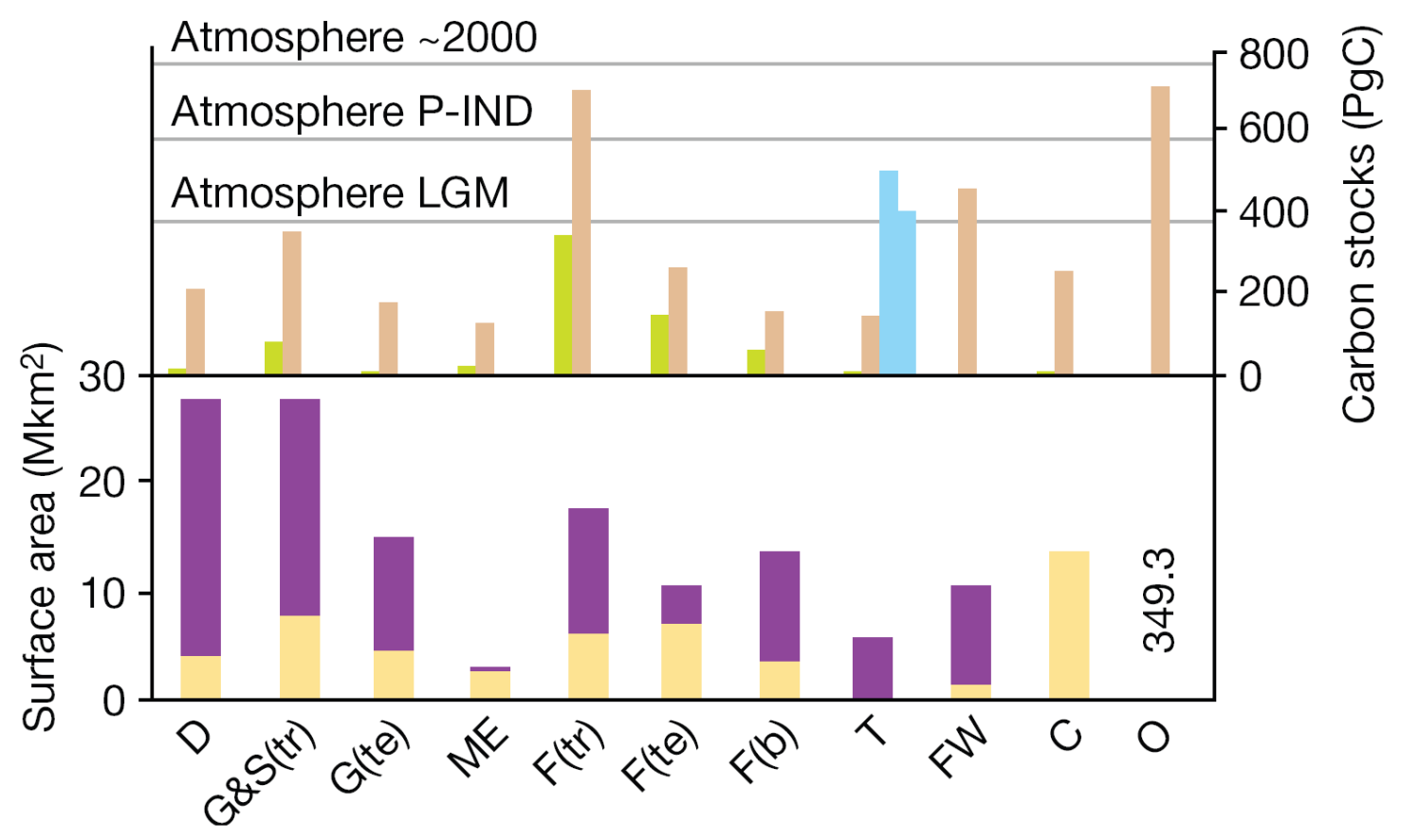

Figure 1. 

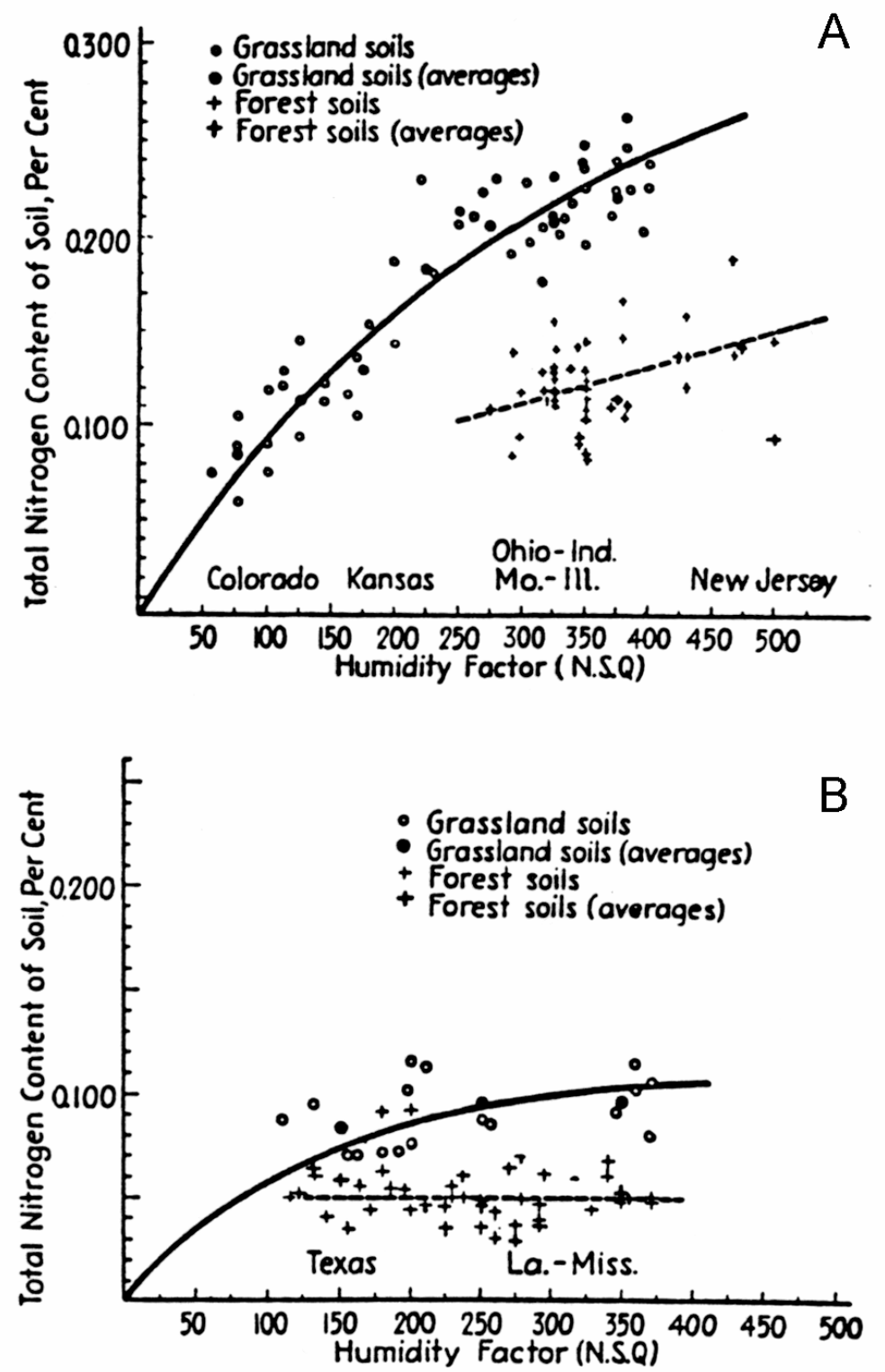

Figure 2. 

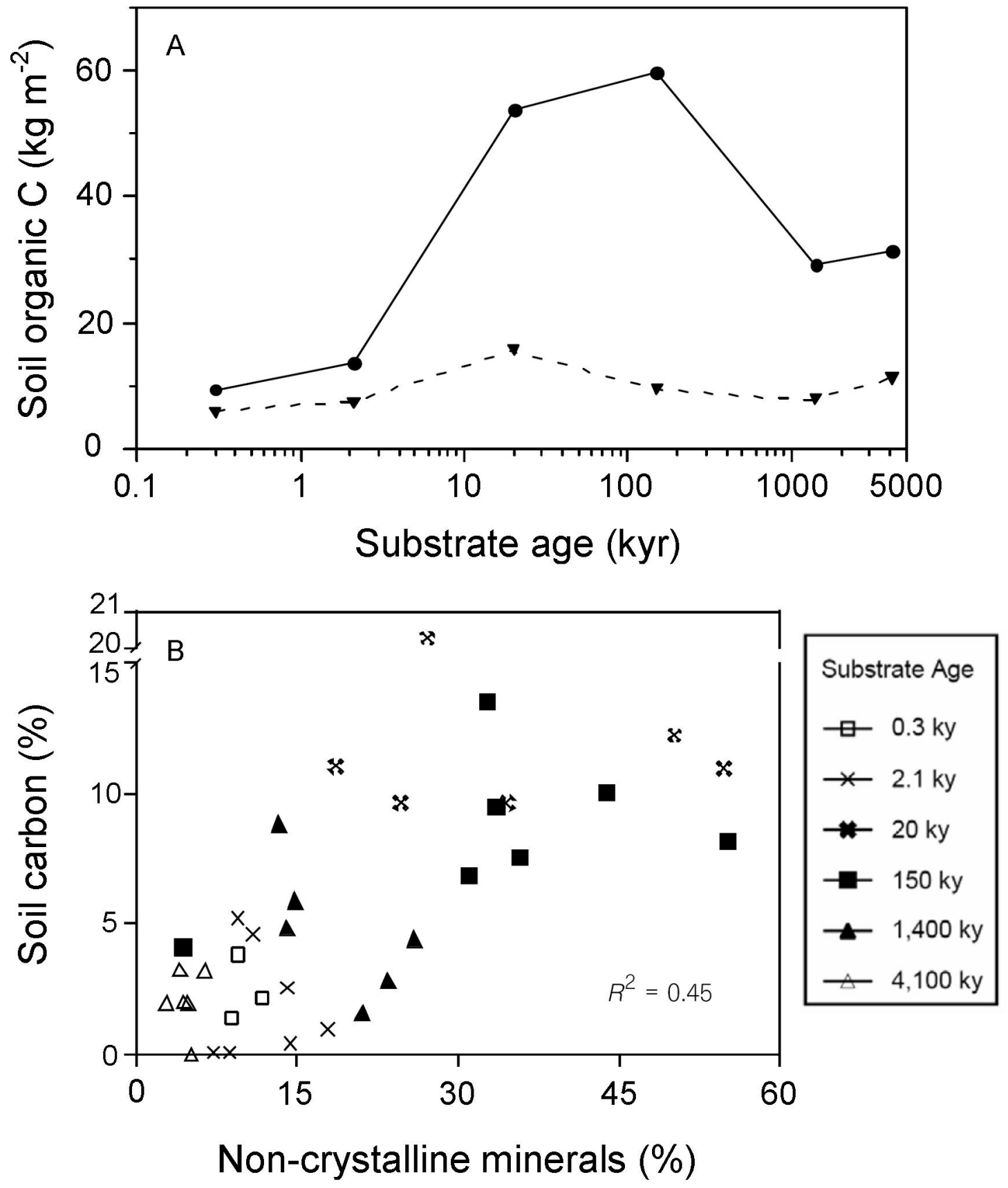

Figure 3 


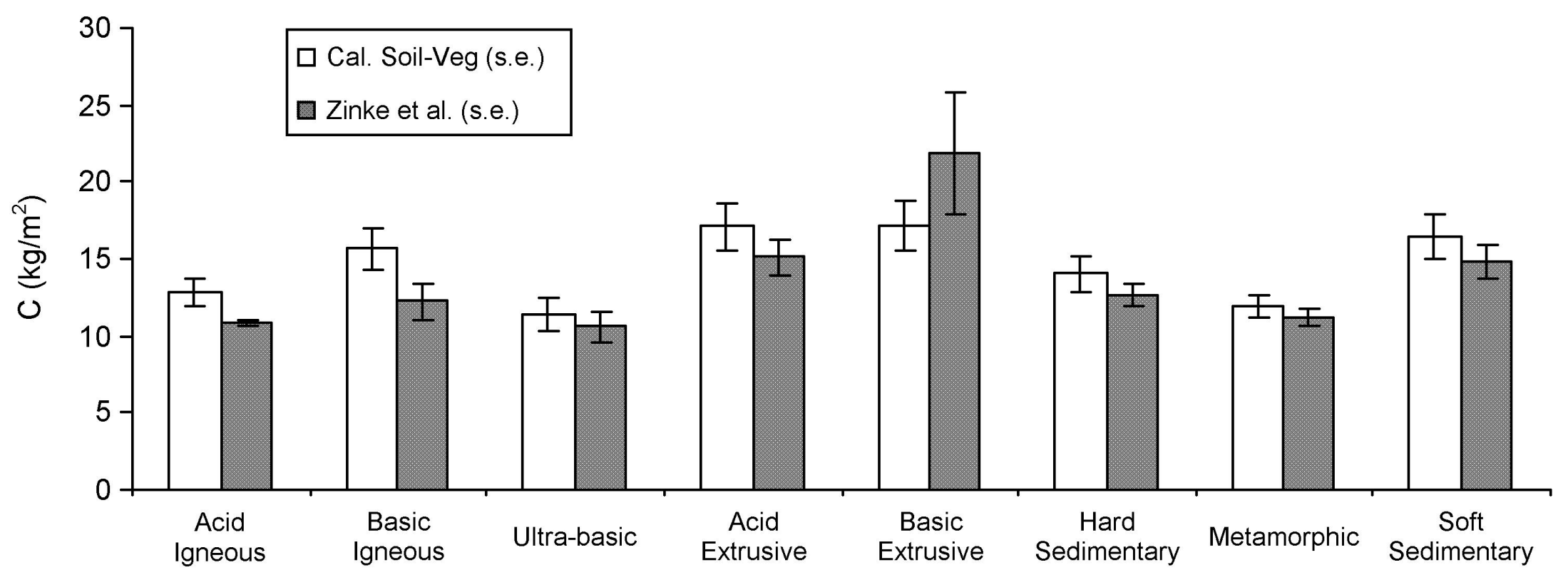

Figure 4 


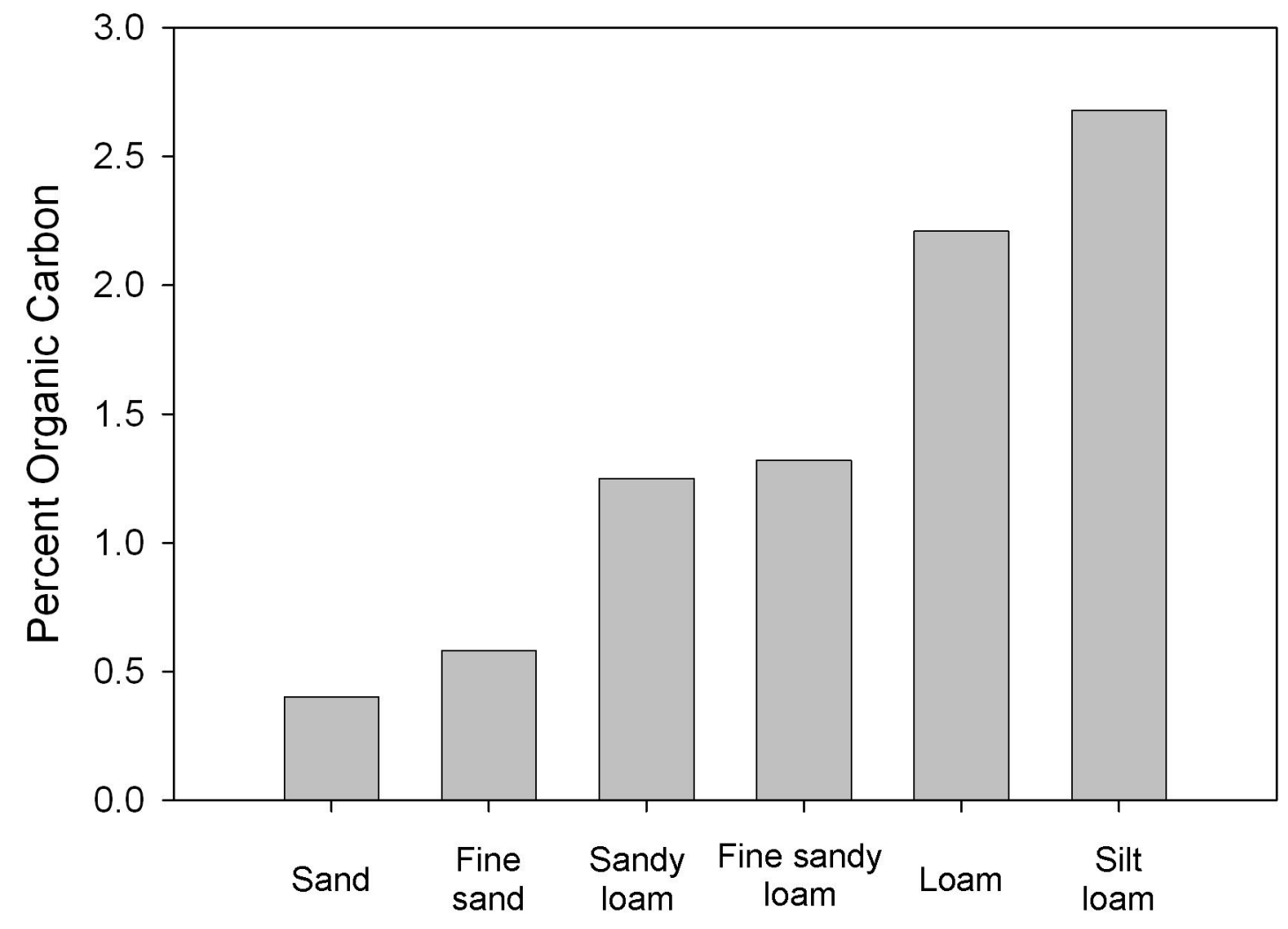

Figure 5 


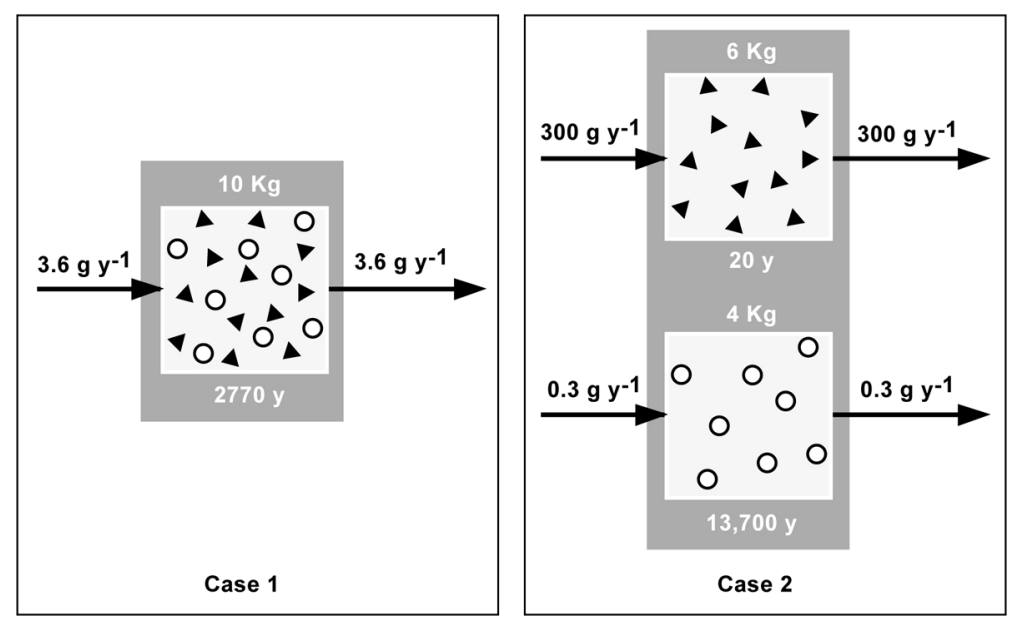

Figure 6 


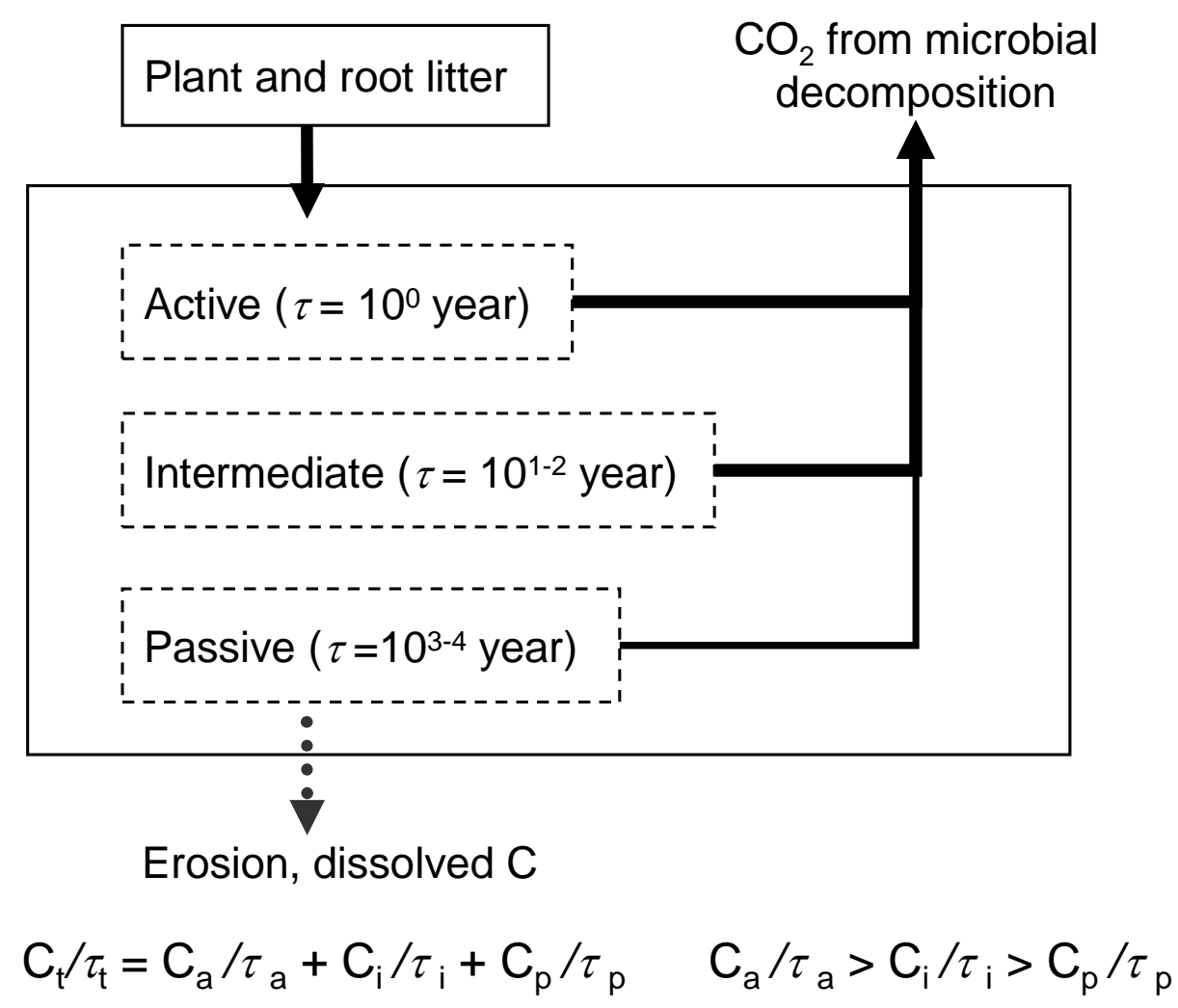

Figure 7 


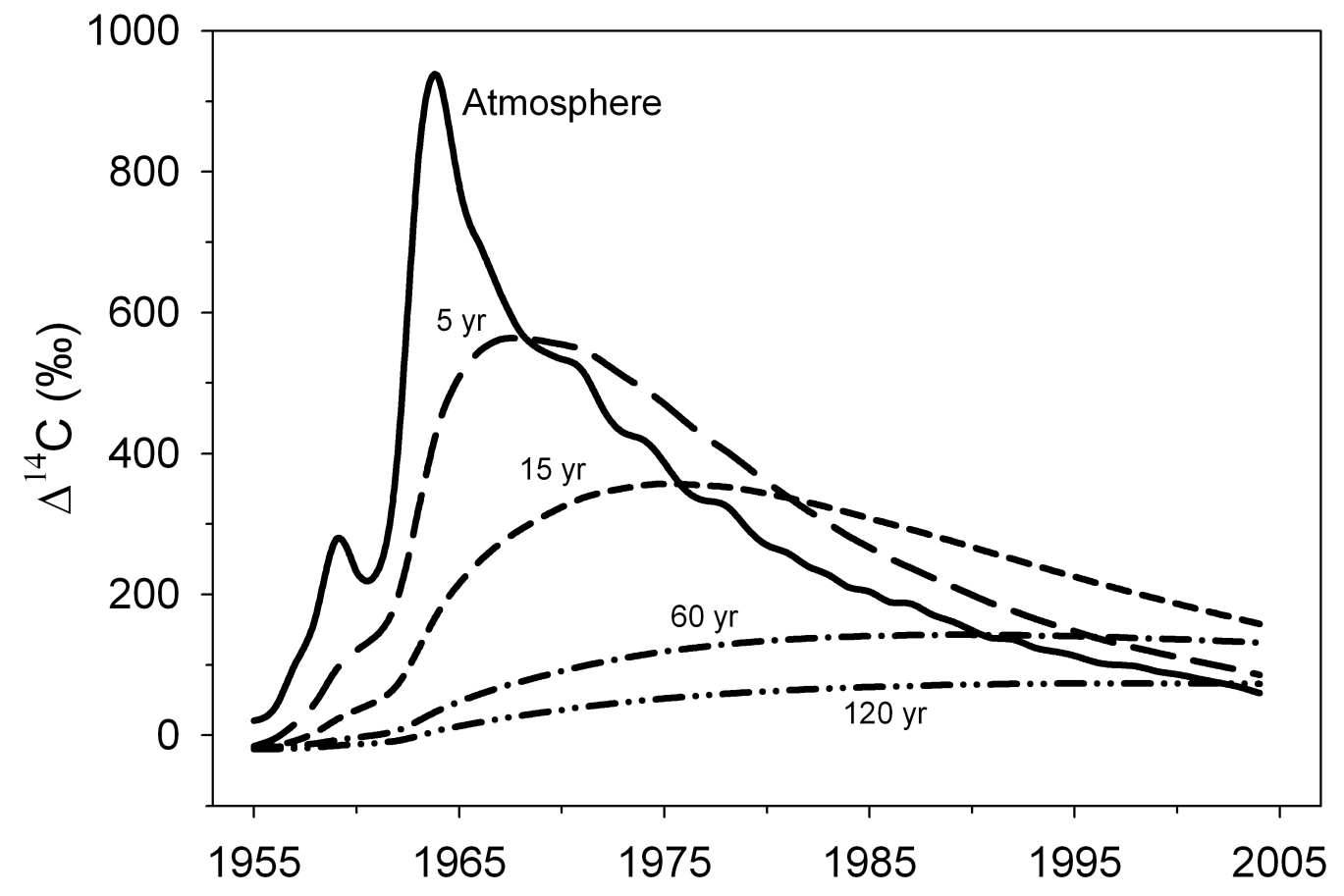

Figure 8 


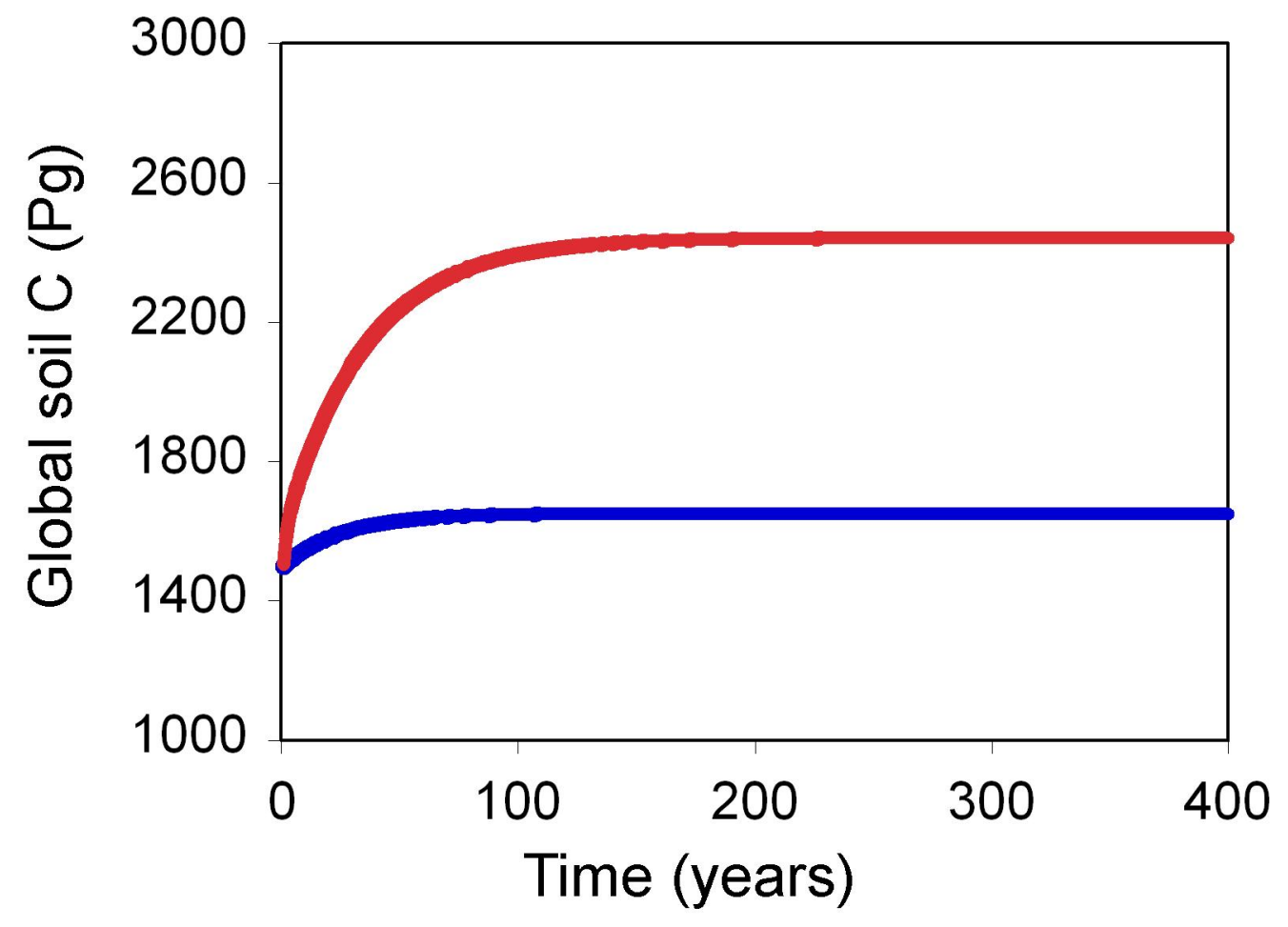

Figure 9 


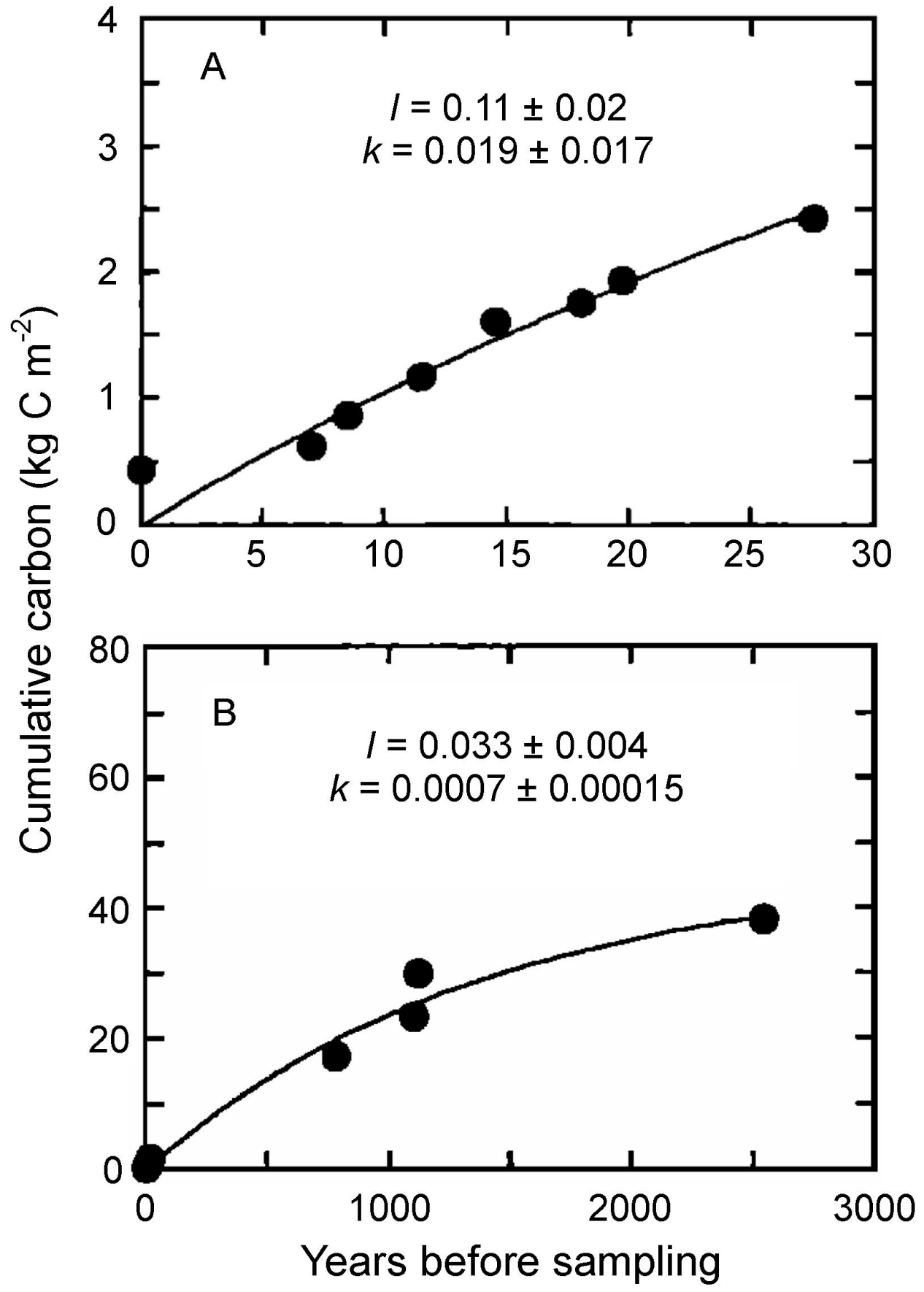

Figure 10 